DOE/EIA-0948(96)/1

Distribution Categary UC-960

\title{
Electric Power Annual 1996 Volume I
}

\author{
August 1997
}

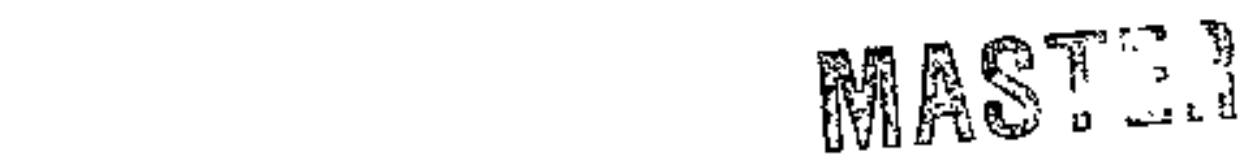

Energy Information Administration

Office of Coal, Nuclear, Electric and Alemate Fuels

U.S. Department of Energy

Washington, DC 20585 


\section{Contacts}

The Electic Powar Amuel is prepared by the U.S. Department of Energy's Energy Informalion Admin'stration. Questions and comrrents concerning the contents of the Elechic Power Amusil may be drected to:

Sandra R. Smith, Froject Manager

Eneroy Information Administration, El-624

U.S. Department of Energy

Washingion, DC, 20685

Telephone number: \{202\}426-1173

Intemet E-Mail number. SANORA.SMITHAEIA.DOE.GOV

or the following subject specialists:

Subject

Nonutility Power Producers Data . . . . . . . . . . .

Generating Capability at U.S. Electric Utilitias . . . . .

U.S. Elactric Utility Net Generation . . $\ldots \ldots \ldots \ldots$

U.S. Elactric Utiliky Consumption of Fuels $+\ldots+\ldots+$.

U.S. Eletric Ulifity Stooks of Fuels . . . . . . . .

U.S. Electrlo Ullity Fossirfyel Receiple ........

U.S. Electric Uttily Fossi-fued Delvered Casts ...

U.S, Ratail Sdes of Electricity, Associated Reventte.

And Average Reverure per Klowathour . .......

Sampling and Estimation Methodologies ........
Contact

Phone Number

Beity WIIlams 202+426-1169

Karen MKDaniel 202-428-1234 KAREN.MCDANEL BEIA.DOE.GOV Malvin E. Johnson 202-426-1172 MELVIN.JOHNSONGEIA,DOEGOV Malwin E. Johnson 202-426-1172 MELVN.HOHNSONOETA.DOEGOV Melvin E. Johnson 202-426-1172 MELVIN.JOHNSON EIA.DOEGOV Kenneih McClevey 202-426-1144 KENNETH.MCCLEVEYOEIA.DOE.GOV Kenneth MoClevey 202-426-1144 KENNETH.MCCLEVEY EIA.DOE.GOV

Linde Bromby 202-426-1164 LINDA.BROWLEYQELA.DOE.COV James Kneub, Jr. 202-426-1145 JAHAES.KNAUB EIA.DOE.GOV

Requests for eddilonsl information on other energy statistles avallable trom the Energy Infomation Administration or qureations concering subscriptions and report diskrbution may be directed to the Natonal Energy lntormatlon Center at 202-586-8800 (TTY: for peopte who are deaf or hasd of hearing, 202-586+1181).

\section{To EIA's Customers}

To ensure that this report meets the highest standards for quality and customer satisfaction, we encourage our readers to contact Sandra R. Smith on (202) 4261173(Internet:SANDRA.SMITH@ELA.DOE.GOV) with comments or suggestions to further improve the report. 


\section{DISCLAIMER}

This report was prepared as an account of woxk sponsored by an agency of the tinlted States Government Nether the United States Government nor any asency thertof; nor any of their empkpees, moke any wartanty, express or ínplied, or assimes any legal liabili. ty or responsibitity for the acouracy, completeness, os usedunness of any informatios, appos. rats, prodoct, or process disdosshi, or represents that jts use wonld not infringe privetely owned rights: Reference berin to any specific conmercial product, proces or servite by

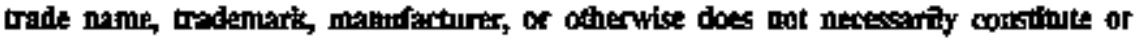

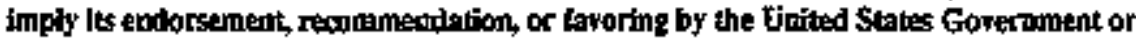
any agency therew. The views and opinions of aettors expectsed herein da not necessar. Hy stalio or relect those of the United States Governunant or any agency thereof. 


\section{Dischoming}

Portions of this document may be illegible in electronic innge products. Imiges are produced from the best available orifinal docenment. 


\section{Electronic Publishing System (EPUB) User Instructions}

EPUB is an electronic publishing system maintained by the Energy Information Administration (EIA) of the US. Department of Energy. EPUB allows the general public to electronically access selected energy data from many of EIA's statistlcal reports. The system is a menu-driven, bulletin board type system with extensive online help opabillties that can be accessed free-of-charge 24 hours a day by using a terminal or PC with an asynchronous modem (EXYB will be taken down briefly at midzight for backup).

PC users must provide the following information to their communications software in order to successfully access the EPUB system.

\section{Communications Parameters:}

Baud Rate: Up to 28,800 bps

Data Bits: 8; Stop Bits: 1

Parity: None; Duplex Full

Terminal Type: ANSI, ANSI-BdS, VT100, etc.

Once your commundcations soltware and/or hardware has been confifgured, EPLJ can be accessed by dialing (202) 586-2557. Whern a connection to the system has been made, some users may find that the menu-diviven instructions and the online help capabilftites will provide enough information to effectively use EPUB. If needed, more extensive information may be found in the EPUD Uster's Guide, which is available online from the EPUB system or from

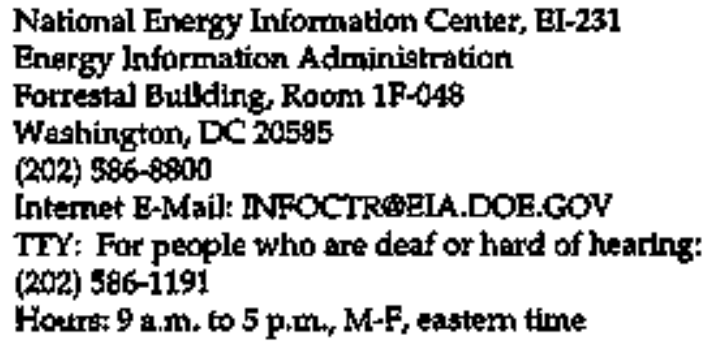

For communtcation or technical assigtance, call (202) 5868959, 8 a.m. to 5 p.m. eastern time, Monday through Friday.

For questions about the content of EPUSB reports and/or data, call (202) 586-8800, 9 a.m. to 5 p.m. eastem time, Monday trough Friday.
Following is a list of some of the data and reports that are provided on EPUB:

- Heating fuel data (April through September) Updated the 2nd week of the month.

- Oxygenate data Updated approximately the 25 th of the month.

- Weaky Petroleum Status Report Updated on Wedresdays (Thursdays in the event of a holiday) at 9 a.m.

- Petroleum Stuply Monthy Updated between the 23rd and 26th of the month.

- Petroleum Marketing Monthly Updated on the 20th of the month.

- Nakurai Gas Monthly Updated on the 20th of the month.

- Weekly Cool Production Updated on Fridays by noon.

- Quarterly Coal Report Updated 40 days after the end of the quarter.

- Electric Power Montily Updated during the first week of the month.

- Monthly Energy Review Upotated the last week of the month.

- Short-Tem Energy Outlook Updated 60 days after the end of the quarter.

- Electric Potoer Annzuit Updated antually. 


\section{Office of Coal, Nuclear, Electric and Alternate Fuels Electric Power Industry Related Data: Available in Electronic Form (as of August 1997)}

\begin{tabular}{|c|c|c|c|c|c|c|}
\hline & \multicolumn{3}{|c|}{ Internat } & \multirow[b]{2}{*}{ Co-ROA } & \multirow[b]{2}{*}{ EPUB } & \multirow[b]{2}{*}{ Dlskelte } \\
\hline & $\begin{array}{l}\text { Portable } \\
\text { Oocument } \\
\text { Fommat } \\
\text { (PDF) }\end{array}$ & $\begin{array}{l}\text { Executable } \\
\text { Data Files }\end{array}$ & $\begin{array}{l}\text { Hypertext } \\
\text { Markup } \\
\text { Language } \\
\text { (HTML) }\end{array}$ & & & \\
\hline \multicolumn{7}{|l|}{ Surveys: } \\
\hline $\begin{array}{l}\text { Form ElA-412: Arnual Report of } \\
\text { Putic Electric Ulitities }\end{array}$ & & $x$ & & & & $x$ \\
\hline $\begin{array}{l}\text { Form EJA-759: Akonthly Power } \\
\text { Plant Report }\end{array}$ & & $\mathrm{x}$ & & $x$ & & $x$ \\
\hline $\begin{array}{l}\text { Form ElA-767: Stanam-Electrle } \\
\text { Operatton and Design Aeport }\end{array}$ & & $\mathrm{x}$ & & & & $\mathrm{x}$ \\
\hline $\begin{array}{l}\text { Form ElA-826: Momhly Electric } \\
\text { Utity Sales and Revenue Report } \\
\text { with State Distributtorns }\end{array}$ & & $x$ & & $x$ & & $x$ \\
\hline $\begin{array}{l}\text { Form EIA-660; Annual Electric } \\
\text { Generator Report }\end{array}$ & & $x$ & & $x$ & & $x$ \\
\hline $\begin{array}{l}\text { Fom ElA-861: Annual Electrici } \\
\text { Utility Repor }\end{array}$ & & $x$ & & $\mathbf{x}$ & & $x$ \\
\hline $\begin{array}{l}\text { FEFC Form 1: Antusl Report of } \\
\text { Higiof Electric Utaities, Licensises, } \\
\text { and Others }\end{array}$ & & $x$ & & & & $x$ \\
\hline $\begin{array}{l}\text { FERC Form 423: Momhly Report } \\
\text { of Cost and Quality of Futls tor } \\
\text { Electric Plants }\end{array}$ & & $x$ & & & & $\mathrm{x}$ \\
\hline \multicolumn{7}{|l|}{ Publications: } \\
\hline Elactrict Power Monthly & $x$ & & & $x$ & $x$ & \\
\hline Electric Power Annual Volume I & $\mathrm{x}$ & & $x$ & $x$ & $x$ & \\
\hline Elactric Power Annual Volume II & $x$ & & $x$ & $x$ & $x$ & \\
\hline $\begin{array}{l}\text { Inventony of Power Ptanis in the } \\
\text { United States }\end{array}$ & $\mathrm{x}$ & & & $\mathrm{x}$ & & \\
\hline Electric Sales and Revenue & $x$ & & $x$ & $\mathrm{x}$ & $x$ & \\
\hline $\begin{array}{l}\text { Financial Statlstics of Major U.S. } \\
\text { Invesior Owned Eleciric Utilities }\end{array}$ & $x$ & & & $x$ & $\mathrm{x}$ & \\
\hline $\begin{array}{l}\text { Financleal Statistces of Mator U.S. } \\
\text { Publichy Owned Electic Utilities. }\end{array}$ & $x$ & & & $x$ & $x$ & \\
\hline
\end{tabular}

Note: In you have amy questions and/or need additionat informatton, please contact the National Energy Information Center at (202) 586-8900. 


\section{Preface}

The Electric Power Annual presents a sumunary of electric power industry statistics at national, regional, and State levels. The objective of the publication is to provide industry decisionmakers, government policy-makers, analysts, and the general public with data that may be used in understanding U.S. electrictty markets. The Electric Power Annual is prepared by the Coal and Electric Data and Renewables Division; Office of Coal, Nuclear, Electric and Aiternate Fuels; Energy Information Admiristration (EIA); U.S. Department of Energy.

In the private sector, the majority of the users of the Electric Power Amual. are researchers and anzlysts and, ultimately, individuals with policy- and decislonmaking responsibilities in electric utility comparies. Financial and investment irstitutions, economic development organi- zations interested in new power plant construction, special interest groups, labbyists, electric power associations, and the news media will find data in the Electric Ponoer Anrual useful.

In the public sector, users include analysts, researchers, statisticians, and other professionats with regulatory, policy, and program responsibilities for Federal, State, and local governments. The Congress and other legislative bodies may also be interested in general trends related to electricity at State and national levels. Much of the data in these reports can be used in analytic studies to evaluate new legislation. Public service commissions and other special government groups share an interest in State-level statistics. These groups can also compare the statistics for their States with those of other jurisdictions.

Volume 1-with a focus on U.S. electric utilities-contains final 1996 data on net generation and forsil fuel consumption, stocks, receipts, and cost; preliminary 1996 data on generating unit capability, and retail sales of electricity, associated revenue, and the average revenue per kilowatthour of electricity sold (based on a monthy sample; Form ElA-826. "Monthly Electric Utility Sales and Revepue Report with State Distributions"). Additionally, information on net genteration from renewable enezgy sources and on the associated generating capability is included in Volume 1 of the EPA. Data published in the Electric Power Annual Volume 1 ars compiled from three statistical forms filed monthly and two forms filed annually by electric utilities. These forms are described in detail in the Technical Noles.

Volume 2-expected to be available in November 1997 - will present other santal data. The second volume will present annual 1996 surmary stalisties for the electric power indus sry, including informatton on nonutility power producers. Incloded in the latter volume will be preliningry data for electric utility retail sales of electricity, associated revenue, and average revenue per kilowatthour of electricity sold (based on the anbual census-Forn EIA-861, "Annual Electric Usility Report") and statistics on electric utility financial and environmental aspects, power transaclions, and demand-side management. Prelinitiary 1996 data for U.S. nonutility power producers on installed capacity and gross generation, as well as suppiy and disposition information, will also be provided in Volume 2 of the EPA. 



\section{Contents}

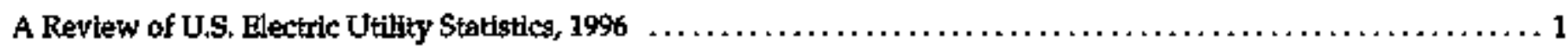

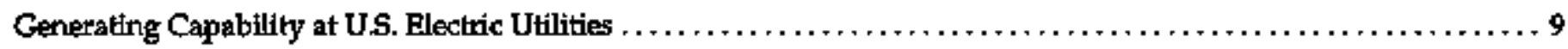

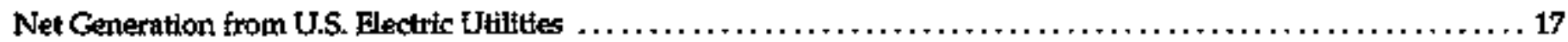

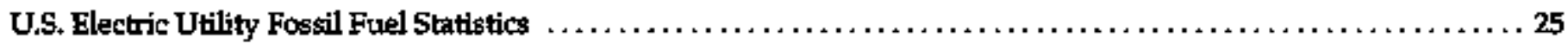

U.S. Electric Uttify Retzil Sales, Revenue, and Average Revenue per Kilowatthour $\ldots \ldots \ldots \ldots \ldots \ldots \ldots \ldots \ldots \ldots$

Appendices

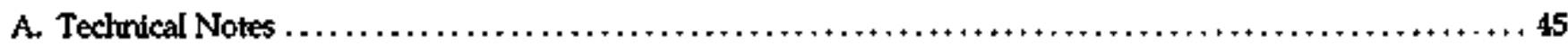

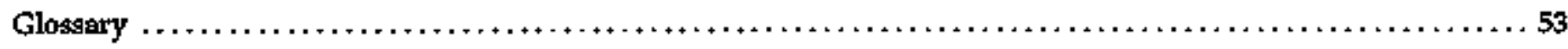




\section{Tables}

1. U.S. Electric Utility Sumnary Statistics, 1995 and $1996 \ldots \ldots \ldots \ldots \ldots \ldots \ldots \ldots \ldots \ldots \ldots \ldots \ldots \ldots \ldots \ldots$

2. Generating Capabilfty at U.S. Electric Utilities by Prime Mover and Primary Energy Source,

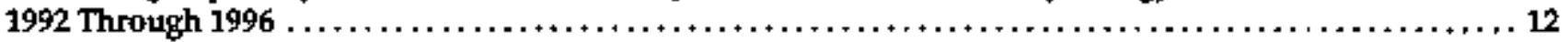

3. Summary of Capability Additions, Retirements, and Total Operable Capability at U.S. Electric Uttlittes

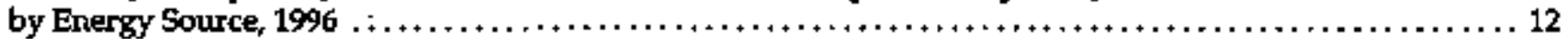

4. Generating Capability at U.S. Electric Utilities by Census Division and State, 1995 and 1996 ........... 13

5. Coal-Fired, Nuclear, Hydroelectric, and Renewable Gentrating Capability at U.S. Electric Utilities by Census Division and Stake, $1996 \ldots \ldots \ldots \ldots \ldots \ldots \ldots \ldots \ldots \ldots \ldots \ldots \ldots+\ldots \ldots \ldots \ldots \ldots \ldots \ldots \ldots \ldots 14$

6. Petroleum-, Gas-, and Dual-Fired Stean Generating Capability at U.S. Electric Utiltites by Census Division and State, $1996 \ldots \ldots \ldots \ldots \ldots \ldots \ldots \ldots \ldots+\ldots \ldots+\ldots \ldots+\ldots \ldots+\ldots \ldots \ldots \ldots \ldots \ldots \ldots \ldots \ldots .15$

7. Petroleum-, Gas-, and Dual-Fired Gas Turbine/Internal Combustion Generating Capability at U.S. Flectric

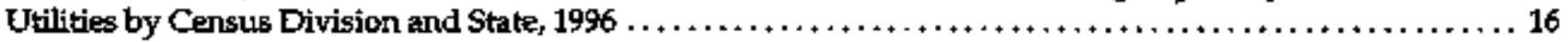

8. Net Generation from U.S. Electric Utilities by Energy Souce, 1992 Through $1996 \ldots \ldots \ldots \ldots \ldots \ldots \ldots \ldots \ldots$

9. Net Generation from U.S. Electric Utilities by Selected Prime Mover, Census Division, and State, 1995 and $1996 \ldots \ldots \ldots \ldots \ldots \ldots \ldots \ldots \ldots \ldots \ldots \ldots \ldots \ldots \ldots \ldots \ldots \ldots \ldots \ldots \ldots \ldots \ldots \ldots \ldots \ldots+\ldots \ldots 19$

10. Ne‡ Generation from U.S. Elextric Ulilities by Energy Souroe, Census Division, ard State, 1995 and 1996 .... 20

11. Petroleum-Fired Net Generation from U.S. Electric Utilities by Selected Prime Mover, Census Diviston, and State, 1995 and $1996 \ldots \ldots \ldots \ldots \ldots \ldots \ldots \ldots \ldots \ldots \ldots \ldots \ldots \ldots \ldots \ldots \ldots \ldots \ldots \ldots \ldots \ldots+\ldots 22$

12. Gas-Fired Net Generation from US. Electric Utlities by Selected Prime Mover, Census Division, and

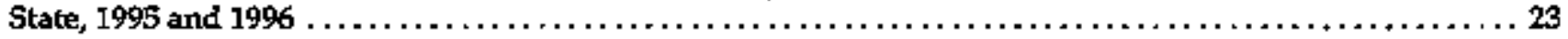

13. Consumption of Fossil Fuels and Year-End Stocks of Coal and Petrokum at U.S. Electric Utilities,

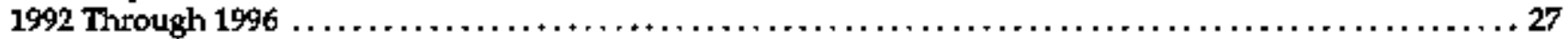

14. Receipts and Average Delivered Cost of Fossil Fuels at U.S. Electric Utilities, 1992 Through $1996 \ldots \ldots \ldots 27$

15. Consumption of Fossil Fuels at U.S. Electric Utilities by Census Division and State, 1995 and $1996 \ldots \ldots \ldots 28$

16. Petroleum Consunption at US. Electric Utilities by Selected Prime Mover, Census Division, and State, 1995 and $1996 \ldots \ldots+\ldots \ldots \ldots \ldots \ldots \ldots \ldots \ldots \ldots \ldots \ldots \ldots \ldots \ldots \ldots \ldots \ldots \ldots \ldots+\ldots \ldots \ldots+\ldots \ldots+\ldots 29$

17. Gas Consumption at U.S. Electric Utilities by Selected Prime Mover, Census Division, and State,

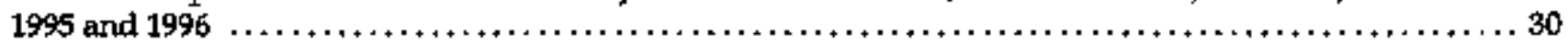

18. Coal and Petroleum Stocks at U.S. Electrle Utilties by Census Division and State, as of December 31 , 1995 and $1996, \ldots \ldots \ldots \ldots \ldots \ldots \ldots \ldots \ldots \ldots \ldots \ldots \ldots+\ldots \ldots \ldots+\ldots \ldots \ldots \ldots+\ldots \ldots \ldots \ldots \ldots \ldots+\ldots, \ldots$

19. Fossil Fuel Receipts at U.S. Flectric Utilities by Cersus Division and State, 1995 and $1996 \ldots \ldots \ldots \ldots \ldots . \ldots$

20. Average Delivered Cost of Fosstl Fuel Receipts at U.S. Electric Utilities by Census Division and State,

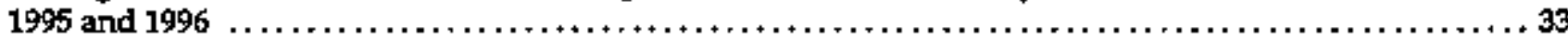

21. Retail Sales by U.S. Electric Utilties to Ultimate Consurners and Associated Revenue by Sector,

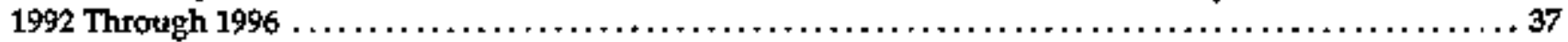

22. Average Revenue per Kilowatthour for U.S. Electric Utilities by Sector, 1992 Through $1996 \ldots \ldots \ldots \ldots \ldots 37$

23. Retail Sales of Electricity by US. Electric Utilities to Ultimate Consumers by Sector, Census Division,

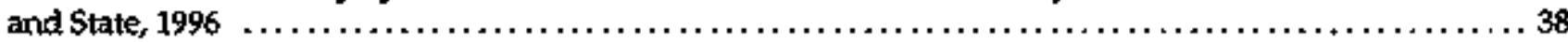

24. Estimated Coefficients of Variation for U.S. Electric Utlity Retall Sales of Electricity by Census

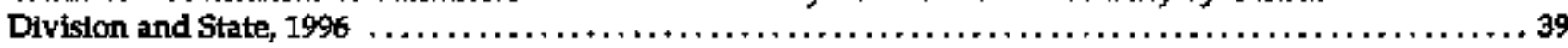

25. Revenue from Retail Sales by U.S. Electric Utilities to Ultimate Consumers by Sector, Census Division,

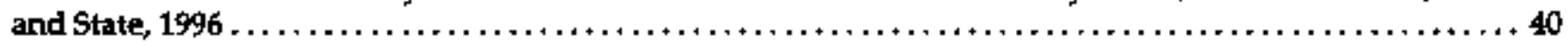

26. Estimated Coefficients of Vartation of Revenue from Retail Sales by U.S. Electric Uttlittes by Census Division and State, $1996 \ldots \ldots \ldots \ldots \ldots+\ldots \ldots+\ldots+\ldots \ldots \ldots \ldots+\ldots \ldots \ldots \ldots \ldots \ldots \ldots \ldots+\ldots \ldots \ldots \ldots+\ldots+41$

27. Average Revenue per Kilowatttour for U.S. Electric Utilities by Sector, Census Division, and State, $1996, \ldots+42$

28. Estimated Coefficients of Variation for Average Revenue per Kilowatthour for U.S. Electric Uttities by Sector, Census Division, and State, $1996 \ldots \ldots \ldots \ldots \ldots \ldots \ldots \ldots \ldots \ldots \ldots \ldots \ldots \ldots \ldots \ldots \ldots \ldots \ldots+\ldots, 43$

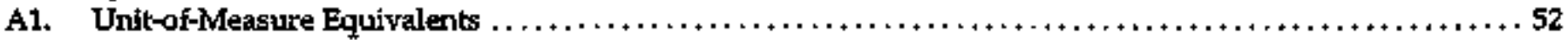

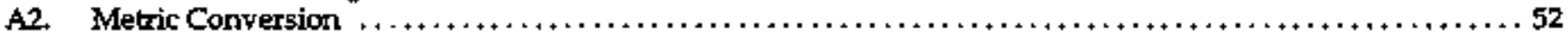




\section{Illustrations}

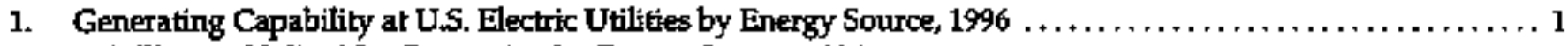

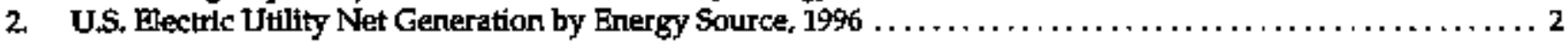

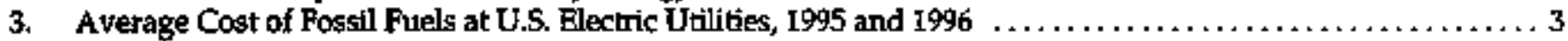

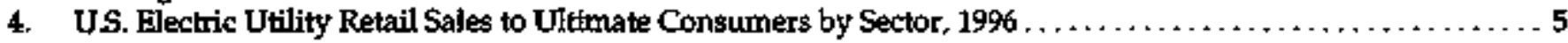

5. US. Electric Utility Average Revenue per Kilowatthour by Sector, $1996 \ldots \ldots \ldots \ldots \ldots \ldots \ldots \ldots \ldots \ldots$ 


\section{A Review of U.S. Electric UtIIIty Statistics, 1996}

\section{Nonutility Power Producers}

Electric power produced by nonutility power producers reenterged as an increasing part of U.S. electricity generation over the past decade. In the $197 \%$ s, the energy erists, inflation, and the high cost of nuclear power resulted in increased clectricity rates and reduced investment in new capacity. These factors led to a re-exalnination of altersative sources of power, such as nomutility electric power, which stimulated the passage of the Publit Utilty Regulatory Palicies Act (PIRPA) of 1978 and other legislation- encouraging growth in the nontaility industry.

For nonutilities (with a nameplate raling of 1 megawatt and greater), the final 1995 and estimated 1996 for year-ent nameplate capacity, gross generation, and sales to electrix ntilities are:

\begin{tabular}{|c|c|c|}
\hline $\begin{array}{l}\text { Nonutillty Power } \\
\text { Producers }\end{array}$ & Final 1995 & $\begin{array}{l}\text { Estlmated } \\
19065\end{array}$ \\
\hline $\begin{array}{l}\text { Nameplate Capacity } \\
\text { (glgawatts) }\end{array}$ & $7 t$ & 73 \\
\hline $\begin{array}{l}\text { Gross Generation } \\
\text { (glgawalthours) }\end{array}$ & 376,475 & 380,008 \\
\hline $\begin{array}{l}\text { Sales to Electrd Utitiles } \\
\text { (gigawathours) }\end{array}$ & 219,653 & 222,202 \\
\hline
\end{tabular}

Source: Fom ElA-687, "Annual Nonutility Power Producer Report." Esilmales were derved using the following procecture. For facilities that havs filed for 1996 and 1995, a growth factor for each data element was calculated [Growh Fantor equals fcurrent year's data divided by kast year's data)]. Estimates are based on information from respondents who make up a6 percert of tolat nameplate capacity in 1905. For facilities that have not filed to cate, their last year'a data were mulkipled by the growth factor of the corresponding data element to derive estimates for the current year. More informetion concerning nomulillyy power producers will be provided in the Electic Power Anmual Volune II(DOEE EIA-348), scheduled for release in November 1997. For more Information, comlact Ms. Batty Willems at (202)426-1269 or E-mail BWillam EIA.DOE.COV..

\section{Generating Capability at Electric Utilities}

Electric utility generating capability in the United States totaled 709,612 megawatts in 1996. ${ }^{1}$ Based on primary energy source, coal-firect capability totaled 302,167 megawatts; gas-fired, 143,208 megawatts; nuclear, 100,685 negawatts; renewables, 77,439 megawatts; petroleum, 65,009 megawatts; and hydroelectric (pumped storage only), 21,104 megawatts. Total capability included 4,394 megawatts of newly added capability. Of that added capability, 35 percent was coal-fired while both gas and nuclear units represented $2 \%$ percent.

Figure 1. Generating Capabllity at U.S. Electric Utilitles by Energy source, 1996

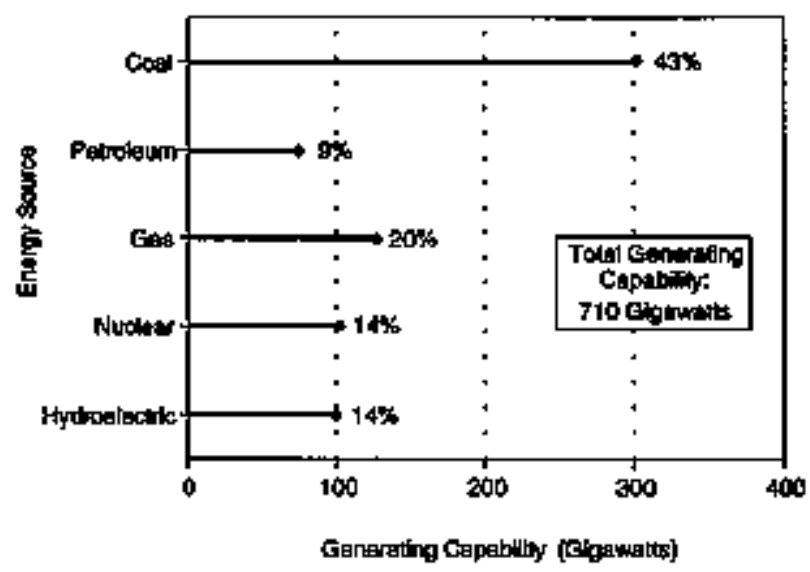

Note8: The total generating capablliry vatue includes renewable generating ceapability (excluding hydroelectic) that Is less than 1 parcent of the total. ePrediminary 1996 data are based on fined 1995 date and changes (includting additions, retirements, and moxillcations) that ocoured in 1996 that were lollowed up and veritted by lelephone using the respontients' proposed tẹn-year changes reported as of Jantiary 1. 1996 . No uptatas from responses subinilted on Form ELAae0 with data as of January 1, 1967 are included. *Totals may not equet sum of components beceuse of independent rounding.

Source; Energy Informalion Administration, Form EIA-860, "Annual Electric Cesnerator Repport."

1 Date on eqpability for 1996 are preliminary; does not include the estimated 73,000 mespawalts of capacity at noputility facilities. 


\section{Net Generation at Electric Utilities}

In 1996, a record level of net generation was set, when 3,077 billion kilowatthours of electricity were produced-an increase of 3 percent from last year. Generation from nuclear power and coal were also at record levels. Although a record was set when 675 billion kilowatthours of electricity were produced from nuclear power in 1996, this level was ondy slightly higher (less than 1 percent) from the level during the previous year. Nuclear power supplied 21.9 percent of the total U.S. electricity production in 1996. Coal-fired generation con tinued to be the largest contributor to the supply of electricity, providing $\mathbf{5 6 5}$ percent of total utility generafion. During 1996, coal-fired plants produced 1,737 billion kilowatthours of electricity, 5 percent above the level during 1995.

Figure 2. U.S. Electric Utllity Net Generation by Energy Solvee, 1996

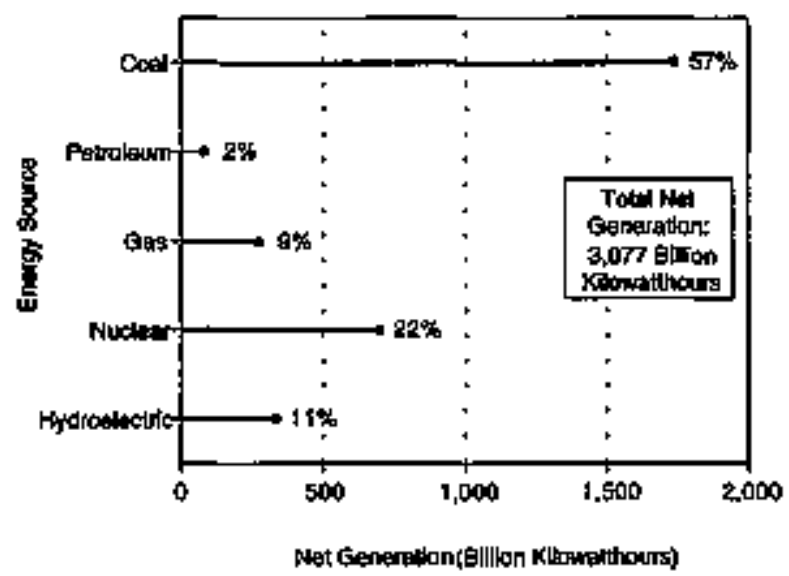

Notes: *The total nat generation value includes renewable energy sources (exclutiling hydroelectrlc), which represent less than 1 percent of tolal generation. -Dala are finat. Totals may not equal sum of components beceuse of independert rounding.

Source: Enetgy Information Administralion, Fom ElA-759, Wontly Power Plant Report."

Conventional hydroelectric generation increased to 331 billionkilowatthours, 12 percent above the level reported during 1995, partly due to improved water conditions in the Pacific Nothwest. Hydroelectric plants in the Pacific Contiguous Census Division, which provided 56 persent of total U.S. hydroelectric generation during the year, reported 9 percent more production than during 1995. Gas-fired generation, however, declined by 15 percent from the level reported in 1995. This decrease was due in part to a substantial increase in the cost of gas in 1996.

\section{Fossil Fuel Recelpts and Costs at Electric Utillties}

In 1996, electric utilities received 863 million short tons of coal, 197 million barrels of petroleum, and 2,605 billion cubic feet (Bcf) of gas at a total delivered cost of approxiIzataly 32 ballion dollars. ${ }^{2}$

Coal accounted for 84 percent of the total Btu content of fossil fuels delivered in 1996, while gas and petroleum accounted for 13 and 3 percent, respectively.

Coal. Electric utilities received a record 863 million short tons of coal in 1996, tp from 827 million short tons received in 1995. This increase in receipts of coal was due primarily to an increase in coal-fired generation that was required to meet a higher demand for electricity. Even with record coal receipts, end-of-year coal stocks fell by 12 million short tons to the $\mathbf{1 1 5}$ million short ton level.

Receipts of coal were indirectly affected by a substantial decrease in the use of gas that was caused primarily by high gas prices. During 1995 the opposite was true when the low-cost of gas ediged out coal at some electric tutilities as the least cost fuel for electric generation. Near record hydroelectric generation limited coal use, especially in the western United States where coal-fired gerreration rose but not to the same extent as in other parts of the country. Receipts of coal actuaily decreased in the Mountain and Pacific Contiguous Census Divisions from 1995 levels. Record nuclear-fired generation in 2996 also limited coal-fired generation; however, on a year-to-year basis, it was up only slightly from 1995 levels.

Continuing the downward trend of the last 11 years, the average detivered cost of coal decreased to $\$ 1.29$ per midion Btu, down from the $\$ 1.32$ per million Btu reported for $1995 .{ }^{3}$ Contributing to this lower cost of coal were an increase in recejpss of low-cost subbituminous coal from Wyoning; the continuing expiration, renegottation, and buyouts of otder high-priced contracts; improved effciency in coal production and transportation; and excess production capacity.

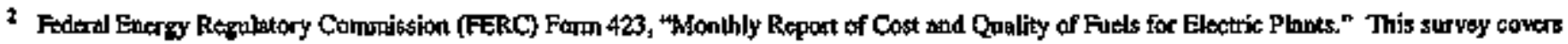
over 99 percent of the copal and approximately 95 percent of the perraleum and gas delivered to electric utilities.

3 The delivered cost of fossid fuels includes al| costs (i.e., transpontation, laxes, etc.) incurrod by the electric ulitity for detivery of the fuel to the plant. 11 does not inctude untording charges. 
Figure 3. Average Cost of Fossil Fuels at U.S. Eleotrlc Utilitle8, 1995 and 1996

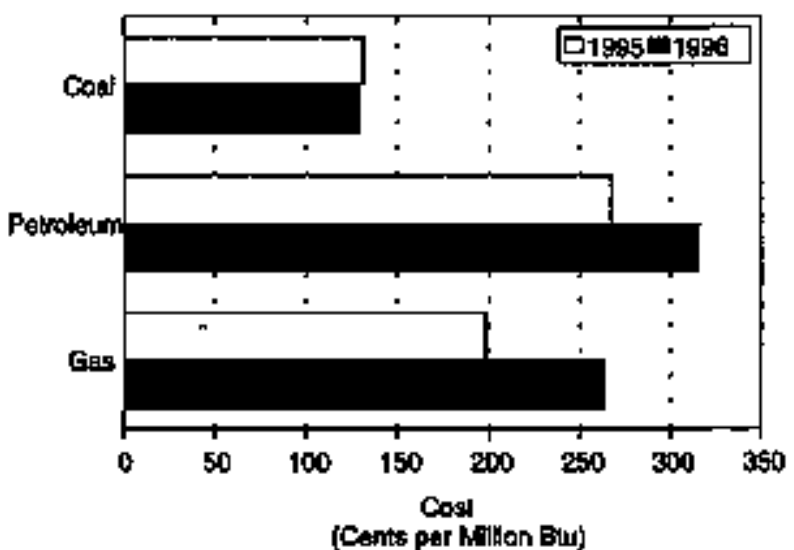

Notes; $*$ Data are final, 1 Data are for edectric generaling plants with a total stoarn-edectric and combined-cycle nameplate ceppecily of 50 or more megewratls. Totals may not equad sum of componems because of Independent rounding. - Data do not Inctude petroleum cokes.

Soutea: Federal Energy Fegulatary Commission. FERC Fom 423, "Wonthly Repout of Cost and Quality of Fuels for Elactitc Plants."

The average cost of coal delivered under contract in 1996 was $\$ 1.31$ per million Btu, down from \$1.36 per mitllion Btr in 1995. On a per stort ton basis the average delivered cost of contract coal was $\$ 26.33$ as compared to $\$ 27.51$ in 1995. However; coal purchased on the spot-market and delivered in 1996 increased in cost. On a dollars per million Btu basis, spot-market coal delivered to electric utilities increased to $\$ 1.20$ per million Btu, up 4 percent from the $\$ 1.15$ per million Btw reported in 1995. On a per-short-ton-basis, the increase in cost of spot-market coal was even more pronounced. The average delivered cost rose 8 percent to $\$ 26.97$ per short ton from the $\$ 24.89$ per short ton reported in 1995.

This increase in cost was due to a combination of higher receipts of spot-market coal from the Appalachian and Interior Regions and a substantial dedine in receipts of western spot-market subbituminotus coal." It is also important to note that the cost of coal on a per-short-ton basis does not fully account for the difference in Btu content of coal from different geographic regions. Subbituminous coal on a per short ton basis is usitally lower in cost than bituminous coal because it has a lower heat content, approximately 8,800 Btu per pound as compared to 10,000 to 13,000 per pound for eastern coal.

Since 1990, the average sulfur content (measured as percent sulfur by weight) of cosl delivered to electric utilities fell each year due to greater use of low-sulfur western coal and to inplementation of the Clean Air Act Amendments of I990 (CAAA90). ${ }^{5}$ However, in 1996, the average sulfur content of cosl delivered was 1.10 percent, up from 1.08 in 1995. The surprising increase in sulfur content was due primarily to an increase in receipts of hitgh-sulfur coal from Indiana, Ohio, and Pennsylvania. Consumption of coal rose in each of these States. In addition, recelpts of low-sulfur coal from Kentucky fell while detiveries of high-sulfur coal rose.

The average Btu content of coal received in 1996 was 10,263 per pound, up from 10,248 per pound in 1995 . Like sulfur, the average Btu content of coll was affected by an Increase in receipts of Appalachian and Interior Region coal Coal from these two regions typically oontain 10,000 and 13,000 Btu per pound, respectively, well above the national average.

Petroleam. Receipts of peroleum detivered to electric utilities totaled 107 million barrels, up from the 84 million barrels reported in 1995. This is opposite the trend of the past several years of lower receipts of petroleum that has resulted from electric utilities turning away from petroleum as a baselond fuel. However, the level of receipts in 1995 was unusually low due to competition from abundant supplies of low-cost natural gas. In 1996, higher gas prices accompanied by a reduction in supplies of gas availabte to electric utilities resulted in a rebound in receipts of petroleum from 1995 levels. Connecticut, Massachusetts, New York, Florida, and Hawaii reported the highest receipts of petroleum. Combined, these States accounted for 76 percent of all petroleum received at electric utilities.

In 1996, the average cast of petroleum was $\$ 3.16$ per million Btu compared with $\$ 2.68$ per million Btu in 1995 . Typically, the cost of petroleum delivered to electric utilities dosely tracks the cost of crude oil. Nutmber 6 fuel oil represented 93 percent of all petroleum products delivered to electric utilities in 1996. Based on a weighted average, fuel oil was the most expensive fossil fuel delivered to electric utilities in 1996.

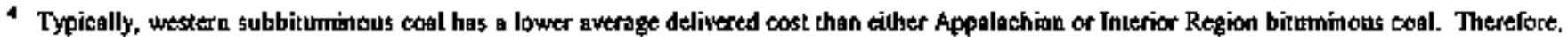

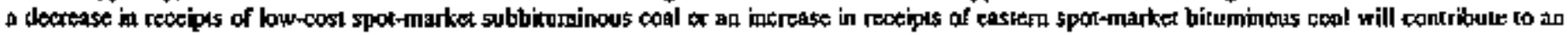
increabe in the national awerage cost of spot-market coal.

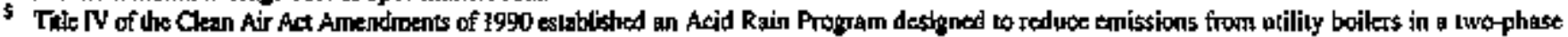
appreach. Starting on January 1, 1995, Phase I set ernission tesurictions on 110 mostb coal-burning plabtg in the caslern and midwestert United Stales. Phase II begins in the year 2000 and places additional emission restrictiong on approximately 1,000 electric plants. To comply with Phase $1_{r}$ many electric ucilities hove increased purchases of low-st:lfur coal whilo reducing purchases of high-sutfur cosh
} 
Gas. Receipts of gas totaled 2,605 Bcf in 1996, down from 3,023 Bcf reported in 1995. This nationtwide decrease in receipts of gas was due in part to a substantial increase in the cost of gas in 1996. Gas became less competitive with other fuels as a fuel source for electric generation. Also, for the second consecutive year, high levels of hydroelectric geveration greatly reduced the use of gas by electric utilities in California. On the other hand, increases in pipeline capacity and the enactment of the CAAA90 which promotes dean-buming gas as a means of reducing emissions, have increased the use of gas by some electric utilities.

On a dollars-per-million-Btu basis, the average cost of gas was $\$ 2.64$ per million Btu, compared with $\$ 1.98$ per million Btu in 1995. While the average cost of gas delivered to electric utilities in 1995 was the lowest since 1979 , the average cost in 1996 was the highest since 1985. Uncertainties concenning the availability of gas, stock levels, and weather were the primary factors influencing changes in the price of gas.

Nuclear Generation Affect on Receipts. In 1996, nuclear-powered plants generated a record 675 billion kilowatthours of electriclty, up 0.2 percent from 1995. At the Census division and State level, however, nuclear-fired generation posted substantial year-to-year changes that affected demand for fossil-fuels. ${ }^{6}$ The New England, Elast North Central, and the South Atlantic Census Divisions each posfed large decreases in nuclear generation. States with substantial decreases in nuclear generation inciude Cormecticut, New Jersey, Illinois, Ohio, Kansas, Florida, and South Carolina, In contrast, the East South Central Census Division posted a 39-percent gain due to a retum to service of Tennessee Valley Authority's Watts Bar (Tennessee) and Browns Ferry (Alabama) nuclear plants. Other States with a 20-percent or more increase in nuclear generation included Maine, New York, and Nebraska.

Weather Conditions Affecting Receipts. Weather that affected the level and timing of fossil fuels received during 1996 lncluded severe cold and snow in the East during January and February, above nortnal winter precipitation in the westem United States, and a relattvely mild summer?

January and February 1996 were cold and wet throughout muxh of the eastern Urited States. Demand for electricity during this period was up considerably from 1995 levels.
Stocks of coal at electric utilities felf to the 116-millionshort-ton level but were replenished during the spring. The summer of 1996 was mith, especially when compared to the interse heat wave which prevailed over much of the Nation during the summer mronths of 1995. The heavily populated Northeast and North Central parts of the Nation were especially mild. Total generation by electric utilities for the June through August period fell by 5 billion kilowatthours from 1995 levels which in-turn negativety affected receipts of fuel.

Heavy precipitation fell in the westem Urited States (in particular Califontia and the Pacific Northwest) during the winter months of December 1995 through March 1996. The area usually receives most of its precipitation during this period at which time a deep snowpack accumulates in the mountains. The subsequent melting during the spring and sumwer helps maintain reservoir levels thuroughout the year and is then the source of hydroelectric generation. The result was the highest level of hydroelectric generation in the Pacific Contiguous Census Division simce 1983. For the year, hydroelectric generation in this Census division rose 10 percent from 1995's high level.

The affect of higher levels of hydroelectric generatton on fossil tuel recelpts was two-fold. First, receipts of gas to Callfornila fell 19 percent to 315 Bcf as hydroelectric plants ran at neaty full capacity reducing the need for gas-fired generation. Second, receipts of coal to the Mountain and Pacific Contiguous Census Divisions fell as Califomia required less coal-by-wire (coal-fired gereration produced in neighboring States and sold over the transtrission grid to electric utilities located in California.)

\section{Retail Sales at Electric Utilities}

Tofal retail sales of electricty to all ultimate consumers in the Uniked Stakes in 1996 reached 3,085 billion kilowatthours, an increase of 71 billion kilowatthours, or 2 percent, compared with 1995 (Table 1). In 1996, sales increased in all major end-use sectors. The residential sector led with an increase of 36 billion kilowatthours ( 3 percent). The commeraal sector followed, increasing by 29 billion kilowatthours (3 percent). Lastly, the industrial sector increased by 2 billion kilowathours, less than 1 percent.

Revenue from the sale of electricity to all ullimate consumers to the United \$tates in 1996 reached $\$ 212$ billion, an Increase of 4 billion dollars (2 percent),

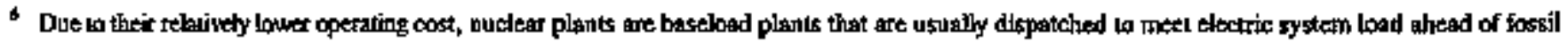

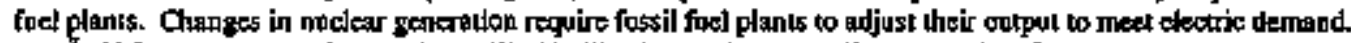

U.S. Depurtment of Agriculure, Weekly Wearher and Crop Bulletin, Yol. 84, No. 2, January 14, 1997.

- Enetgy Information Admintstration, Electric Power Mosthily (EPH), DOE/EIA-(2226(97N03), Table 11.
} 
Flgure 4. U.S. Electrlc Utillty Retail Sales to Ujtimate Consumers by Sector, 1996

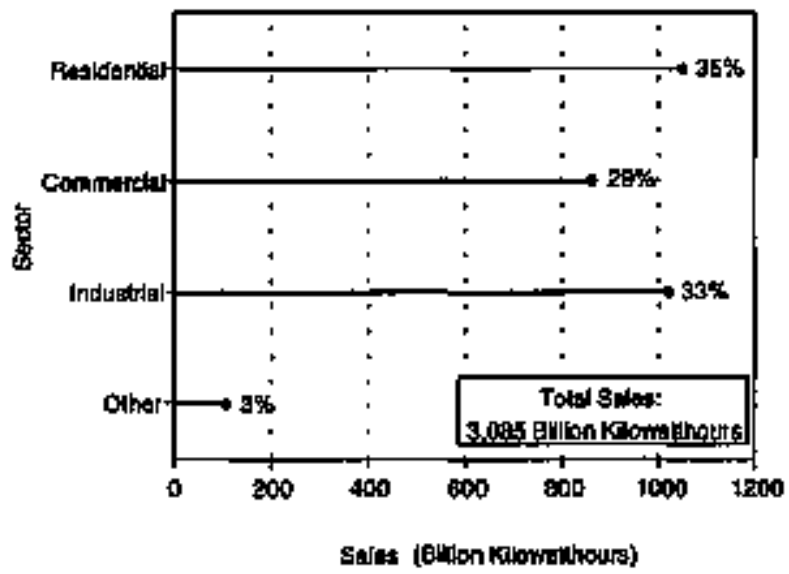

Noles: Oiner includes publk street and hlghway lghing, olher sales to publle euthorlies, sales to reilroads and ralhwys, and interdepertrinental stales. toitals misy not equal sum of components because of independent rotunding.

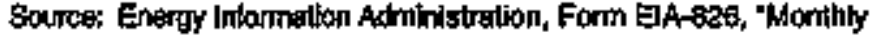
Electrk Uiblily Sales and Revenue Report wilh Siate Dfsifibuttons."

compared with the level in 1995 . Electricity revenue in the resldentfal and commercial sectors increased by 3 blllion and 2 bjllion dollars, respectively. Revenue from sales of electricity in the industrial sector decreased slighty.
Flgure 5. U.S. Electric Utlity Average Revenue per Kilowatthour by \$ector, 1996

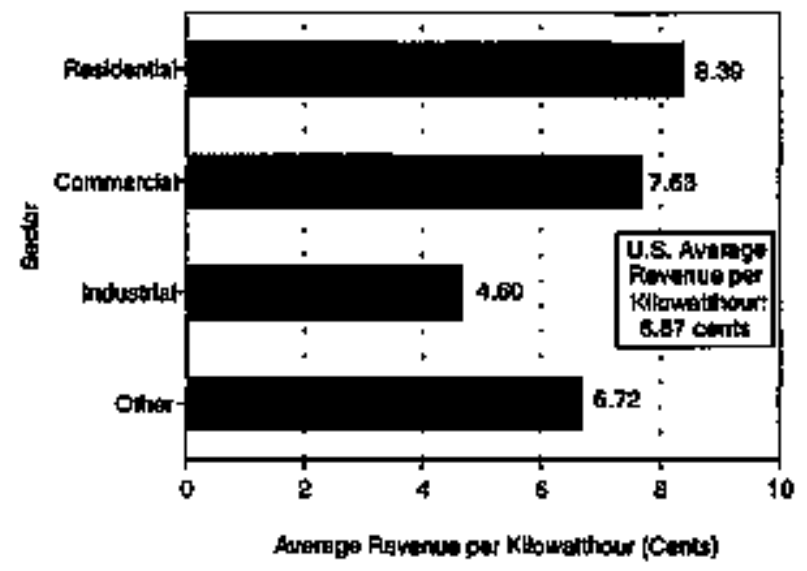

Noles: -Other Inciudes sales to pubdic stretel and highway Honing, other sales to public authorilies, sales to raitroads and ralhways, and interdepartimental sales. Walues are weighted and are calculated by dividing total reverue by total salas.

Source: Energy Information Adminisiration, Form ELA-626, Thanthy Electils Utilly Sales and Revenue Report wilh Stale Distrtbutions."

Average Revenae per Kilowatthour' of electricity sold to ultmate consumers in 1996 was 6.87 cents, a decrease of 0.02 cents from 1995. In both the commercial and industrial sectors, average revenue per kilowatthour decreased by 0.06 cents. Average revenue per kftowatthour in the residential sector decreased by 0.01 cents.

In 1996, estimated U.S. Ntal retail sales of etectricity (3,085 billion kilowatthouxs) exceeded total net generation by U.S. electric wifltes by 7 bilion silowathours (less than 1 percent). The major factor contibuling to this difference was net import of electrictity totaling 39 billian kliowatthours (EIA estimate based on preliminary data from the National Energy Board of Cartada and U.S. Department of Energy. Fassil Energy).

9 Awerage newane per kfiowatthour is the ratio of revenue to retoil salies. 
Table 1. US. Electric Utility Snmmary Statisties, 1995 and 1996

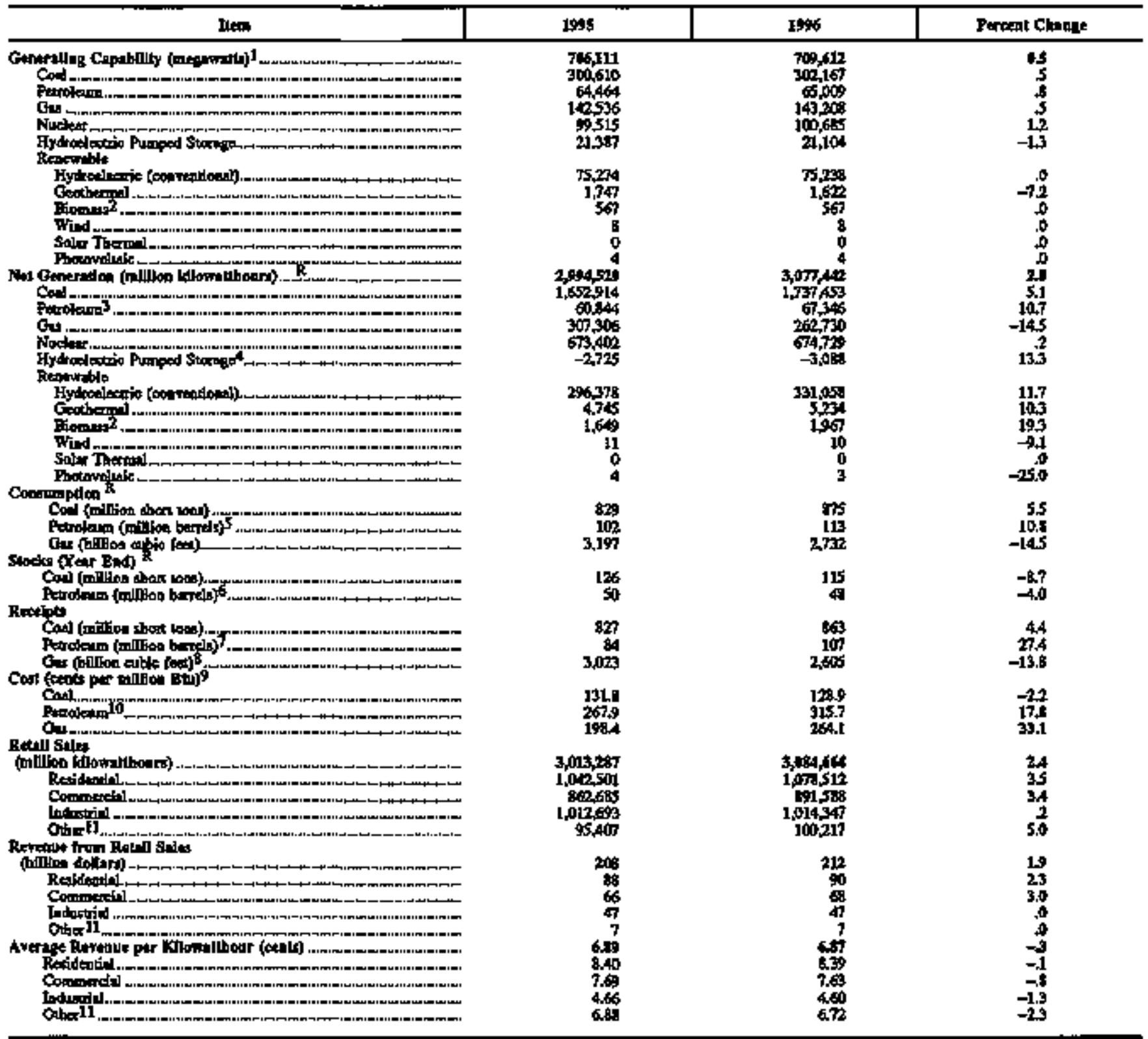

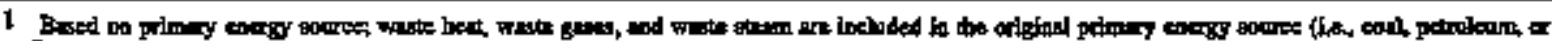

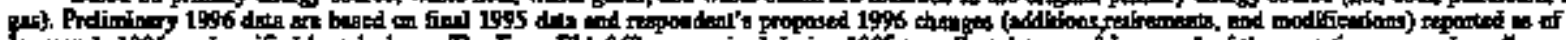

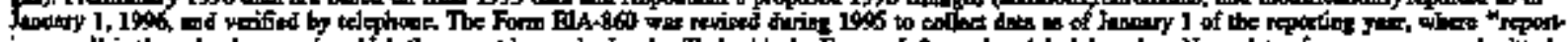

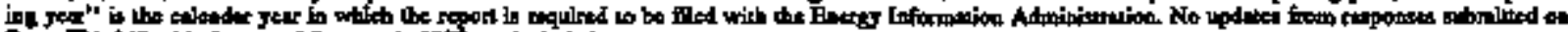

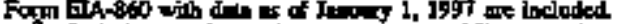

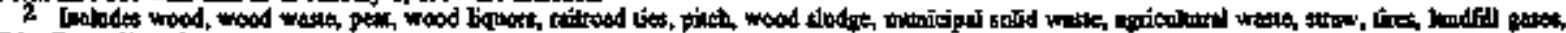

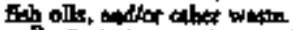

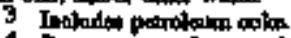

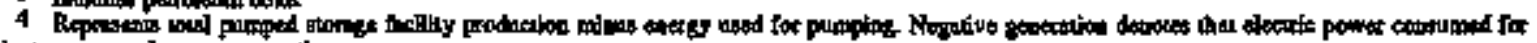

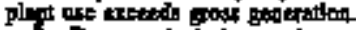

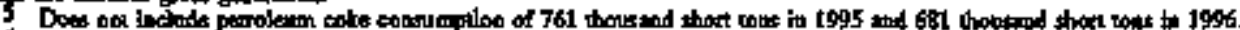

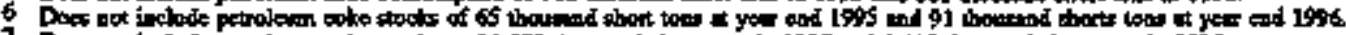

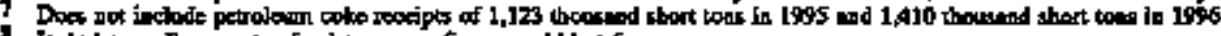

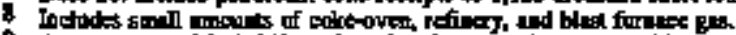

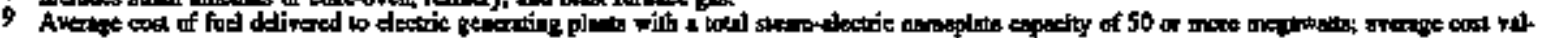

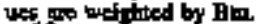

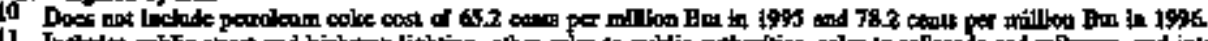

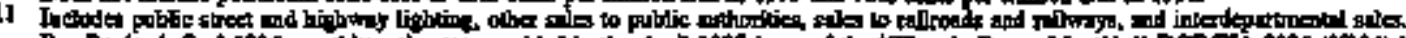

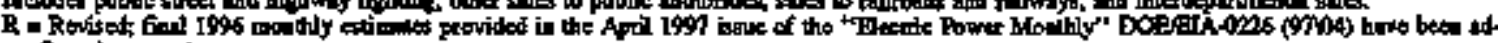

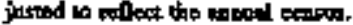




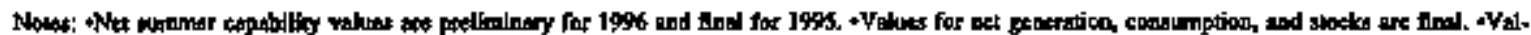

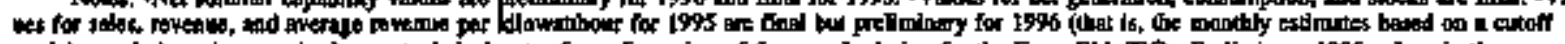

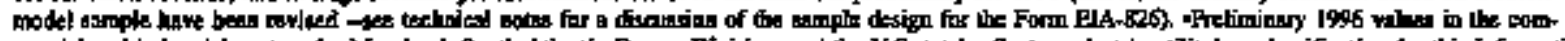

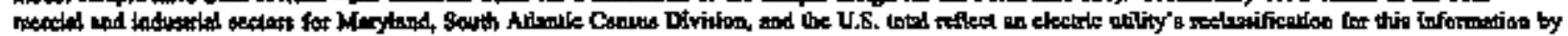

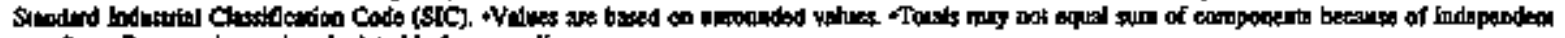

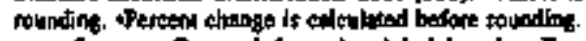

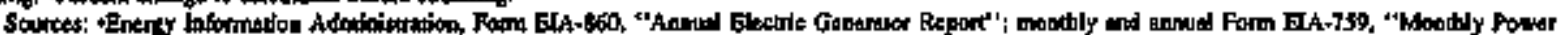

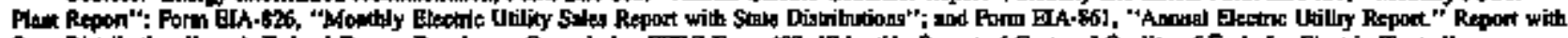

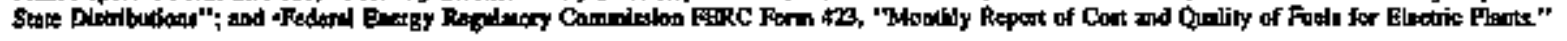


$$
-
$$ 


\section{Generating Capability at U.S. Electric Utilities}

More than one-third of the primary energy in the Nation is used to generate electricity ${ }^{10}$ Consumers expect eiectricity to be instantly available; that is, at the flick of a switch In fact, electricity is so important to the functioning of our society that its unavailability is newsworthy. The U.S. electric power industry is organized to ensure that an adequate supply of electricity is available to meet all demand requfrements at any given instant, boh now and in the future. This chapter provides an inventory of the capability of various methods for converting energy into electricity, and information regarding industry plans for builiding additional capability in the future.

The generating units operated by an electric utility vary by intended usage; that is, by the trree major types of load (genekally categorized as base, intermediate, and peak) requirements the utility must meet. A beselond generating unit is normally ued to satisfy all or part of the minimum or base load of the system and, as a consequence, produces electrictity at an essentrally constant rate and runs continuously. Baseload units are generally the newest, largest, and most efficien "' ${ }^{\text {t }}$ of the three types of units. A peaklond generating unit, normally the least efficient of the three unit types, is used to meet requirements diuring the periods of greatest or peak load on the system. Intermediate-load generating units meet system requirements that are greater than base load but less than peak load. Intermediate-load units are used during the transition between baseload and peak load requirements. Utilities also have reserve or standby generating units, which are available to the system in the event of an unexpected increase in load or an unexpected outage withtn the system. Consequently, an inventory of net capability must account for reserve or standby capability, as well as generafing units that are not available to the system for vartous reasons (such as routine maintenance).

Net capability in this report, unless otherwise stated, refers to that which is opernble and includes both active and inactive capabiliky. Once a new generator has been ceclared available to generate power to the electrical grid, it is considered a part of the operable capability of the utility until it is retired from service. Generating units that are used for standby service, cold standby, and gernerators that are out of service for an extended period (exceeding 1 year) comprise the inactive operable capability. ${ }^{12}$ Active operable capability includes generators that are generating or available to generate; this includes generators that may be down for scheduled maintenance, refueling, or forced outages.

An electric utility plant (station) contains generating units and awxiliary quipment that are used to convert various types of energy into electric energy. A fossil-fueled generating unit may be designed to use (bum) one or more fossil fuels to produce electricity. A generating urit capable of burning more than one fossil fuei is referred to as a dual-fired unit. Sorne duat-fired units can only burn one fuel at a time (that is, the fuels are fired sequentially), while others can burn more than one fuel simultaneously (comcument firing of different fuels). A sequentially fired unit generally uses one fossil fuel as its primary energy source, but can switch to a second fossil fuel as an altemate energy source. Unless stated otterwise, information regarding generating capabitity in this report is based on the primary energy source.

\section{Prime Movers}

Electric utilities use a variety of prime movers based on the Joads, availability of fuels, and energy requirements of the utility. The trost common prime movers are the steam turbine, internal-combustion engine, gas combustion turbine, water turbine, and wind turbine. ${ }^{13}$ Most prime movers used to produce electricity today are turbines. The energy sources most oftern used with prime movers are the fossil ftels-coal, petroleum, and natural gas.

Steam-Turbine Generating Units. Most of the electricity in the United States is produced in steam turbines. In a

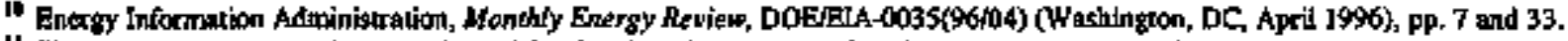

II The aperating efloiency of a geserating wit is a function of the amount of net heat that ix can extract from the energy source for use in the production of electricicy.

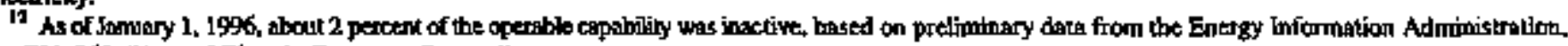
Form ElA-860, "Anmill Electric Gentator Rqport"

13 A tuctite convoris the kinctic energy of a mowing fluid (liqujd or gas) to mecthanical energy. Turbines have a series of blades mounted on a shat

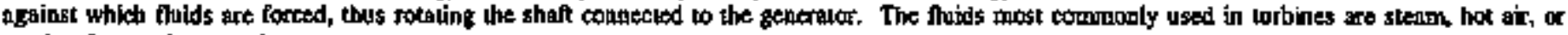
cambuestan products, and watex.
} 
fossil-fucled steam turbine, the fuel is bumed in a boiler to produce steam. The resulting steam then turns the turbine blades that tum the shaft of the generator to produce electricity. In a nuclear-potucted steam turbine, the boiler is replaced by a reactor containing a core of nuclear fuel (primarily enriched uranium). Heat produced in the reactor by fission of the uranium is used to make steam. The steam is then passed through the turbine generator to produce electrictity, as in the fossil-fueled steam turbine. Steam-tutbine generating units are used potmanty to serve the base load of electric utilities. Fossil-fueled steam-turbthe generafing units range in size (nameplate capacity) from 1 megawatt to more than 1,000 megawatts. The size of nuciear-powered steam-turbine generating tunits in operation today ranges from 75 megawatts to more than 1,400 megawats.

Gas Turbine Generating Units. In a gas turbine (combustion-turbine) unit, hot gases produced from the combustion of natural gas and distillate oil in a high-pressure combustion chamber are passed directly through the turbine, which spins the generator to produce electricity. Gas turbines are commonly used to serve the peak loads of the electric utility. Gas-turbine units can be installed at a variety of site locations, because their size is generally less than 100 megawatts. Gas-tutbine units also have a quick startup time, compared with steam-turbine units. As a result, gas-turbine units are suitable for peaking emergency, and reserve-power requirements.

The gas turbine, as is typical with peaking units, has a lower effidency than the steam turbine used for baseload power. The effidency of the gas funtine is increased when coupled with a steam turbine in a combinet-cycle operation. In this operation, hot gases (which have already been used to spin one turbine generator) are moved to a waste-heat recovery steam boiter where the water is heated to produce steam that, in tum, produces electricity by running a second steam-uubine generator. In this way, two generators produce electriclty from one initial fuel input. All or part of the heat required to produce steam may come from the exhatust of the gas turbine. Thus, the steam-turbine generator may be supplementarily flred in addition to the waste heat. Combtned-cycle generating units generally serve intermediate loads.

Internal-Combustion Eingines. These pume movers have one or more cylinders in which the conbustion of fuel takes place. The engine, which is connected to the shaft of the generator, provides the mechanical energy to drive the generator to produce electricity. Internal-combustion (or diesel) generators can be easily transported, can be insialled upon short notice, and can begh producing electricty nearly at the moment they start. Thus, like gas turbines, they are usually operated during periods of high demand for electricity. They are generally about 5 megawatts in size.

Hydroelectric Generating Units. Hydroelectric power is the result of a process in which flowing water is used to spin a turbine connected to a generator. The two basic types of hydtoelectric systems are those based on folling water and those based on neinot tiver current. In the first system, water accumulates in reservoirs created by the use of dams. This water then falls through conduits (penstocks) and applies pressure against the turbine blades to drive the generator to produce electricity. In the second system, called a run-of the-river system, the force of the river current (rather than fallng water) applies pressure to the turbine blades to produce electricity. Since run-of-the-river systems do not usually have reservoirs and carnot store stubstantial quantities of water, power production from this type of system depends on seasonal changes and stream flow. These conventional hydroelectric generating units range in size from less than 1 megawatt to 700 megawatts. Because of their ability to start quickly and make rapid changes in power output, hydroelectric generating units are stitable for serving peak kads and providing spinning reserve power, as well as serving baseload requitements.

Another kind of hydroelectric power generation is the pumped storige hydroelectric system. Pumped storage hyctoelectric plands use the same principle for generation of power as the conventional hydroelectric operations based on falling water and river current. However, in a punped storage operation, low-cost off-peak energy is used to pump water to an upper reservoir where it is stored as potential energy. The water is then released to flow back down through the turbine generator to produce electricity dutuing periods of high demand for electricity.

Other Generating Units. Other methods of electric power generation, which presently contribute only small amounts to total power production, have potential for expansion. These include geothernal, solar, wind, and biomass (wood, municipal solid waste, agricultural waste, etc.). Geofhermal power comes from heat energy burned beneath the surface of the earth. Although most of this heat is at depths beyond current drilling methods, in some areas of the country, magmat flows close enough to the surface of the earth to produce steam. That steam can then be harnessed for use in conventicnal steam-turbine plants. Solve power is derived from the energy (both tight and heat) of the sun. Phototoltaic contoersion generates electric power directly from the light of the sun; whereas,

If Magsina is the moleen matter under the earth's crugt from while igneont rock is formed by cooling. 
soldr-thermal electric generators use the heat from the sun to produce stean to drive turbines. Wind power is derived from the conversion of the energy contained in wind into electricity. A wind turbine is similar to a typical wind mill. However, because of the intermittent nature of sunlight and wixd, high capactly utilization factors cannot be achieved for these plants. Several electric utillies have incorporated zuod and uaste (for example, municipal waste, com cobs, and oats) as energy sources for producing electrictity at their power plants. These sources replace fossil fuels in the boiler. The combustion of wood and waste creates steam that is typically used in conventional steam-electric plants.

\section{Generator Rating}

The rating of a generator is a measure of th ability to produce electricity. Generators are rated by niameplate capacity. The nomeplate capacity is the full-load continuous rating of the generator under specified conditions, as designated by the manufacturer, and is usually indicated on a metal plate attached to the generator. Net capability is the steady hourly output that the generating unit is expected to supply to the system load, as demonstrated by test procedures. The capability of the generating unit in the summer is generally less than in the winter due to high ambient-air and cooling-water temperatures, which cause generating units to be less efficient. The measure used in this publication for electric utilities is net summer capability. The nameplate capacity of a generator is generally greater than its net capabitity.

\section{Data Sources}

The following tables contain a summary of the number of electric generators and the amount of electric generating capability in the United States at national, regianal, and State levels for the period 1992 through 1996. During the past year, several updates were made for these data.
These changes indude the installation of new generators; the retirement of existing generators; the use of a primary energy source for dual-fired units different from that whict has been reported in the past; and the modification of generators, such as the rewinding of stators or the retrofitting of associated generator equipment. Respondents that did not meet the reporting requirements of Form EIA- $\$ 60$ were deleted. The capacity of generators sold to nonutilities was also deleted. The inclusion of new respondents also resulted in data changes.

Estimates of net surnmer capability and net winter capability are made for operable nonnuclear electric generating units with no reported capability. These estimates are calculated using a statistical relationship that exists between the capabllity (summer and winter) and installed generator nameplate capacty for units that were in commercial operation as of the end of 1992. For a description of the estimation formula, see the tecturical notes.

Data in the tables were obtained from the Form EIA-860, "Annual Electric Generator Report." Data are reported annually on the Form EIA-860 by approximately 900 electric utilities in the United States that operate power plants. The Form ELA-860 was revised during 1995 to collect data as of January 1 of the reporting year, where "reporting year" is the calendar year in which the report is required to be filed with the Energy Information Administration.

Data from the Form EIA-860 for 1996 are prelininary, based on final 1995 data and respondents' proposed 1996 changes (additions, retirements, and modifications) reported as of January 1, 1996, and verified by teleptrone. Data prior to 1995 are as of December 31 of the reporting year. Final data, as well as more detailed statstics on operable capacity and planned capability additions, are published in the inventory of Powter Plants in the United States. ${ }^{15}$

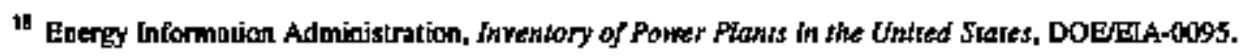


Table 2. Generating Capabllity at U.S. Electric Uttitles hy Prime Mover and Primsry Enexgy Source, 1992 Through 1996

(Megawatis)

\begin{tabular}{|c|c|c|c|c|c|}
\hline Prlme MoweriPrumary Doerd Soune & $199 \mathrm{n}$ & 1939 & 1994 & $2+955$ & $1995^{2}$ \\
\hline 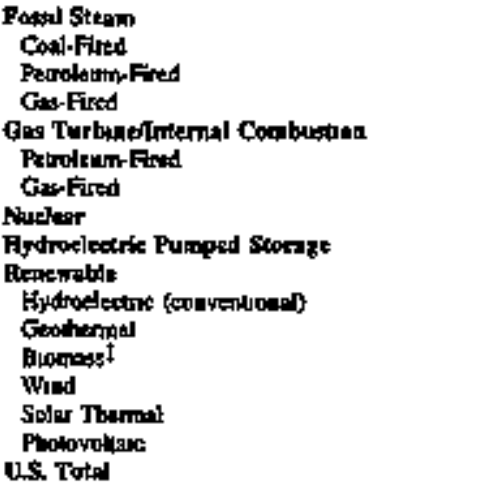 & 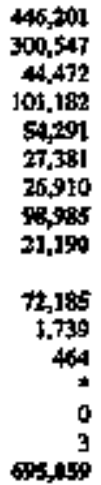 & $\begin{array}{r}46,315 \\
300,795 \\
41,906 \\
103,614 \\
56,494 \\
27,614 \\
28,881 \\
99,041 \\
21,146 \\
74,763 \\
1,747 \\
459 \\
1 \\
0 \\
4 \\
690,971\end{array}$ & $\begin{array}{r}44,734 \\
301,088 \\
41,151 \\
102,985 \\
99,577 \\
28,768 \\
30,849 \\
39,248 \\
31,2188\end{array}$ & 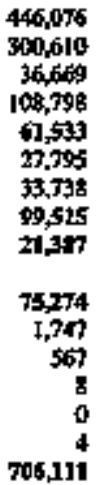 & $\begin{array}{r}47,316 \\
302,167 \\
36,736 \\
109,399 \\
69,089 \\
29,273 \\
34,814 \\
100,695 \\
31,164 \\
79,201 \\
1,602 \\
367 \\
8 \\
0 \\
4 \\
709,612\end{array}$ \\
\hline
\end{tabular}

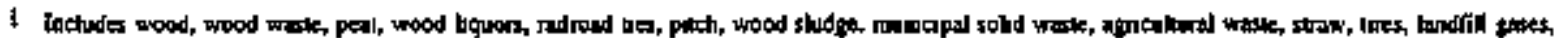

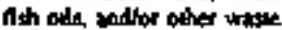

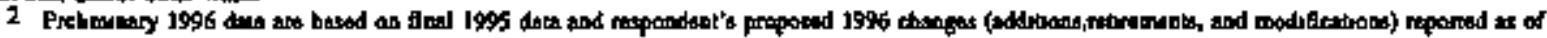

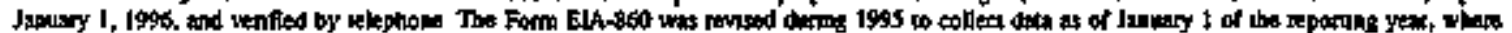

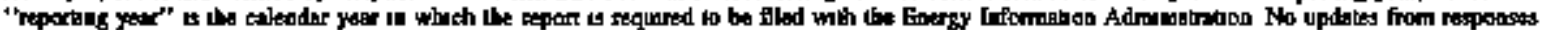

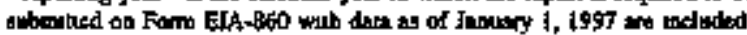

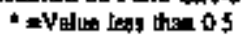

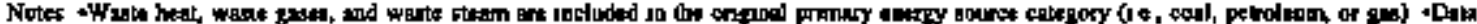

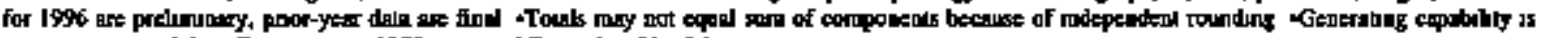

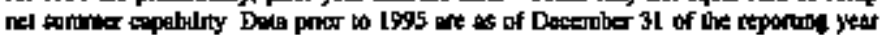

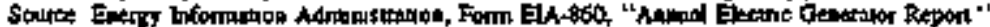

TabHe 3. Summary of Capability Additions, Retirements, and Total Operable Capability at U.S. Electric Utilittes by Energy Sonrce, 1996

\begin{tabular}{|c|c|c|c|c|c|c|}
\hline \multirow{2}{*}{$\begin{array}{c}\text { Pdriary Energy } \\
\text { Sorre }\end{array}$} & \multicolumn{2}{|c|}{ Added } & \multicolumn{2}{|c|}{ Redired } & \multicolumn{2}{|c|}{ Operable } \\
\hline & $\begin{array}{l}\text { Nember of } \\
\text { Genertitors }\end{array}$ & 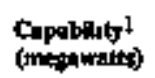 & $\begin{array}{l}\text { Shiber of } \\
\text { Centhilits }\end{array}$ & 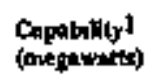 & $\begin{array}{l}\text { Nomber of } \\
\text { Gentertidit; }\end{array}$ & 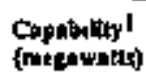 \\
\hline 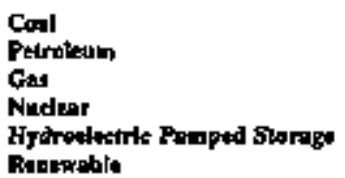 & $\begin{array}{r}6 \\
24 \\
24 \\
1 \\
0\end{array}$ & $\begin{array}{r}1,555 \\
472 \\
1,180 \\
1,170 \\
0\end{array}$ & $\begin{array}{l}0 \\
4 \\
1 \\
0\end{array}$ & $\begin{array}{r}0 \\
0 \\
0 \\
0\end{array}$ & $\begin{array}{r}1,218 \\
3,304 \\
2,259 \\
110 \\
159\end{array}$ & $\begin{array}{r}302_{1}, 167 \\
65,009 \\
143,208 \\
10,1985 \\
21,104\end{array}$ \\
\hline 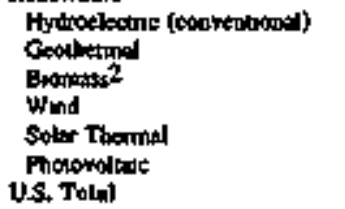 & $\begin{array}{r}4 \\
0 \\
0 \\
0 \\
0 \\
0 \\
0 \\
0\end{array}$ & $\begin{array}{r}7 \\
0 \\
0 \\
0 \\
0 \\
0 \\
1,394\end{array}$ & $\begin{array}{l}0 \\
2 \\
0 \\
0 \\
0 \\
0 \\
6\end{array}$ & $\begin{array}{r}0 \\
126 \\
0 \\
0 \\
0 \\
0 \\
185\end{array}$ & $\begin{array}{r}3342 \\
27 \\
27 \\
18 \\
0 \\
9 \\
10,499\end{array}$ & $\begin{array}{r}75,258 \\
1,622 \\
567 \\
8 \\
0 \\
4 \\
709,612\end{array}$ \\
\hline
\end{tabular}

I Het swmer capahilicy

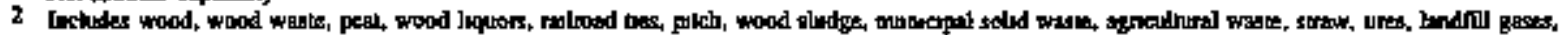
fih alk, and tor ather wrate

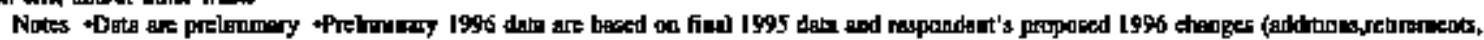

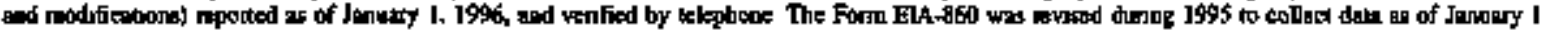

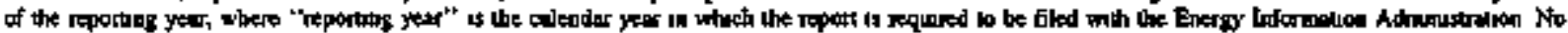

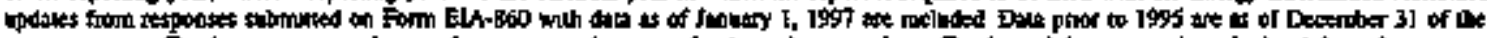

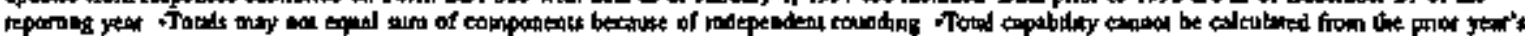

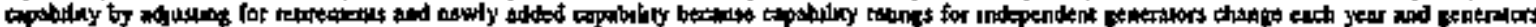

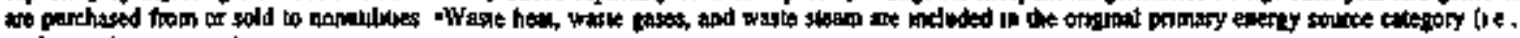
cod, partilewor, of gas)

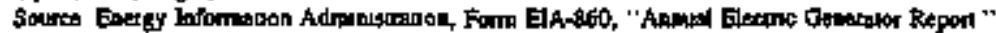


Table 4. Generating Capability at U.S. Electric Utilities by Census Division and State, 1995 and 1996

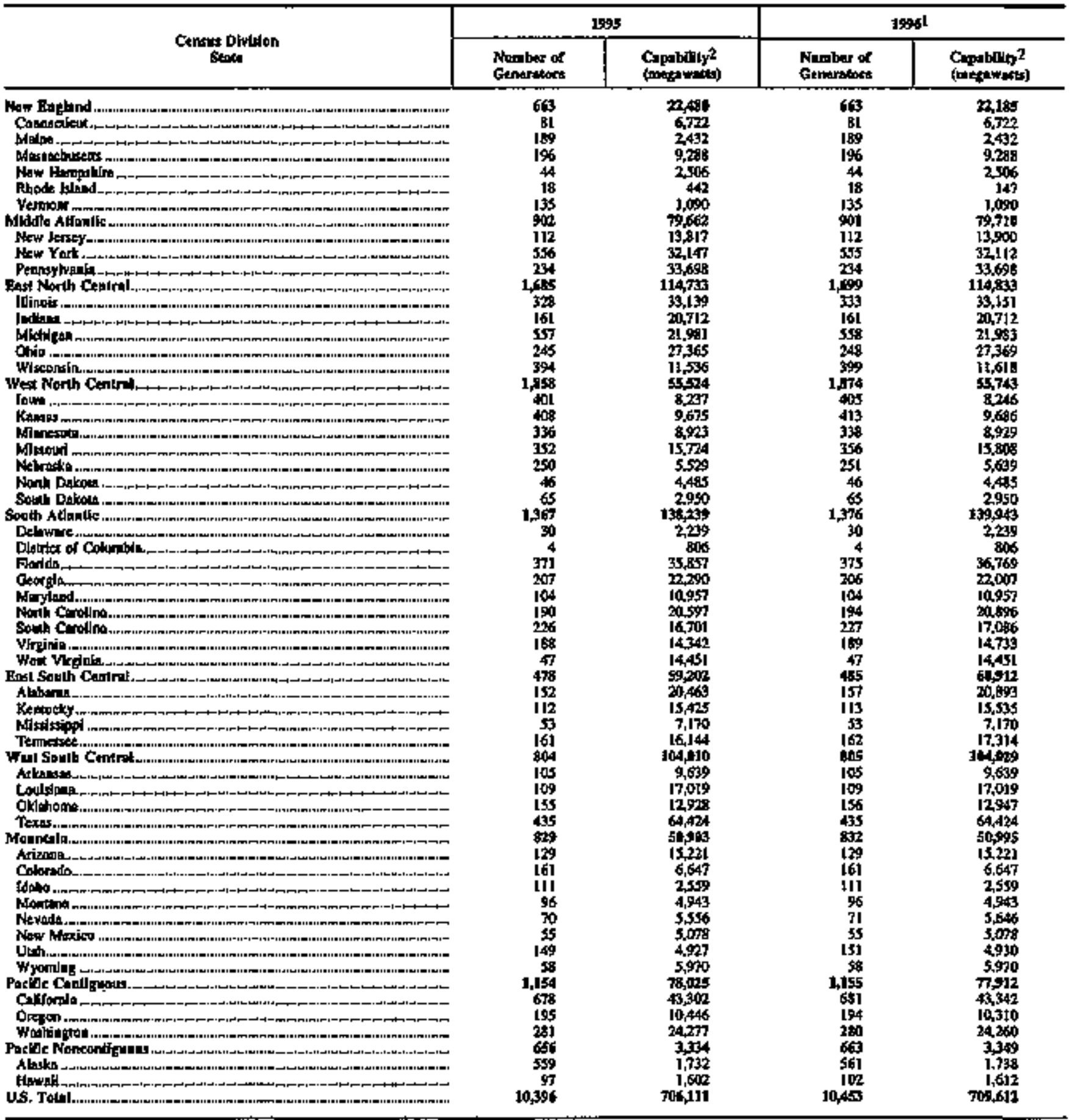

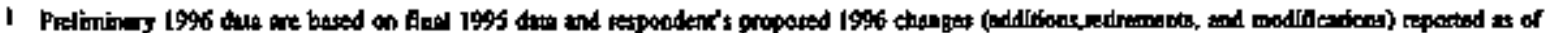

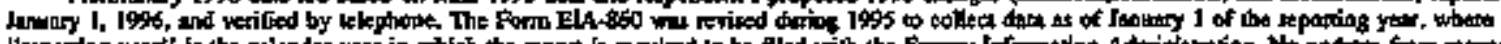

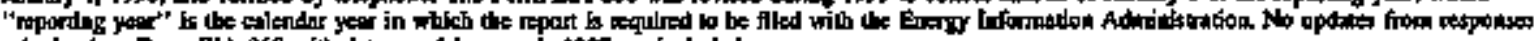

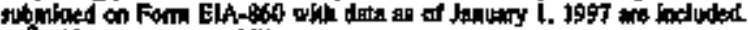

2 Net mminer enplidiry.

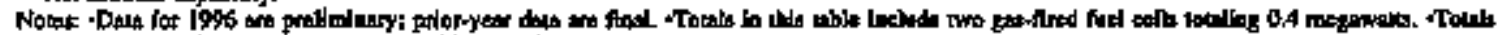

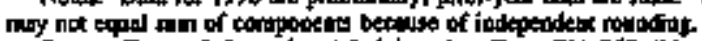

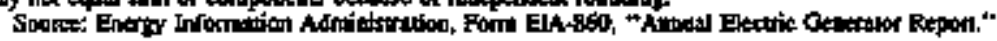


Table 5. Coal-Fined, Nuclear, Hydroelectrk, and Renewable Generating Capability at U.S. Electric Utillties by Census Division and State, 1996

\begin{tabular}{|c|c|c|c|c|c|c|c|c|}
\hline \multirow{2}{*}{$\begin{array}{c}\text { Cencus Drintion } \\
\text { Sinte }\end{array}$} & \multicolumn{2}{|c|}{ Cont } & \multicolumn{2}{|c|}{ Mudger } & \multicolumn{2}{|c|}{ Styrtodedtele } & \multicolumn{2}{|c|}{ Reatorablot } \\
\hline & $\begin{array}{l}\text { Number of } \\
\text { Gencestors }\end{array}$ & $\begin{array}{l}\text { Capablity } \\
\text { (inteportuts) }\end{array}$ & Numper of & $\begin{array}{l}\text { Cropabdlity } \\
\text { (nitoswitits) }\end{array}$ & $\begin{array}{l}\text { Nonber of } \\
\text { GeneratorT }\end{array}$ & 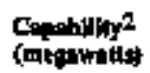 & $\begin{array}{l}\text { Number of } \\
\text { Cennerators }\end{array}$ & 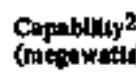 \\
\hline 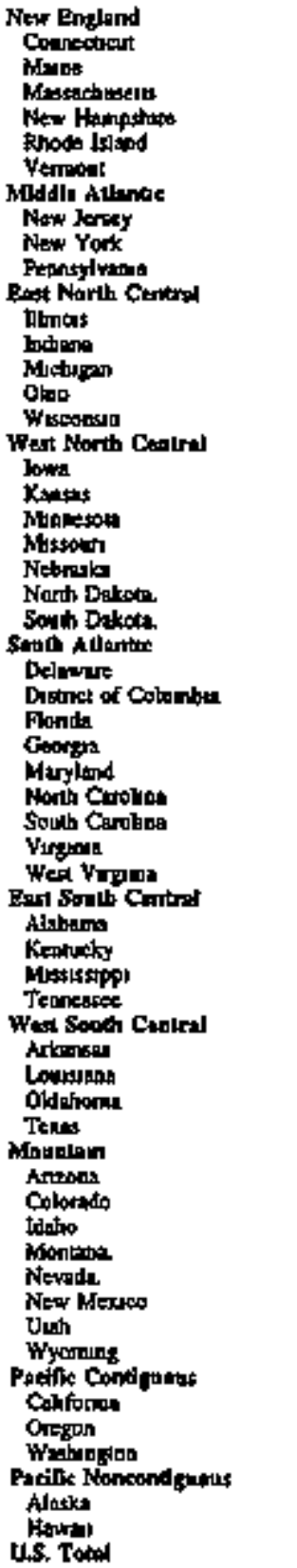 & 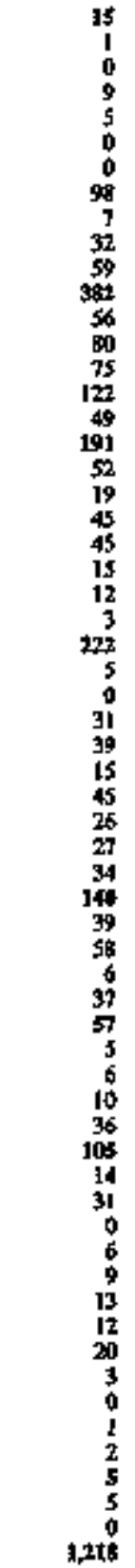 & 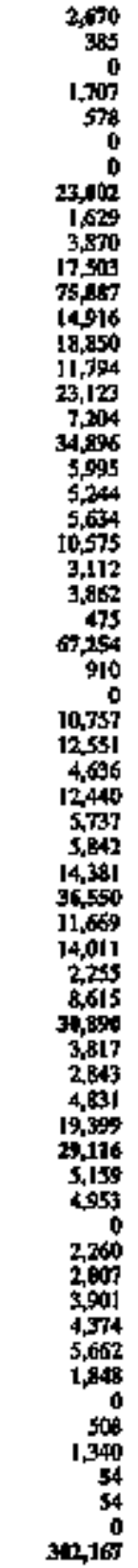 & 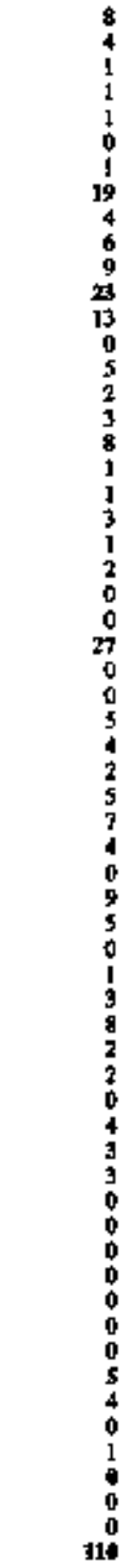 & 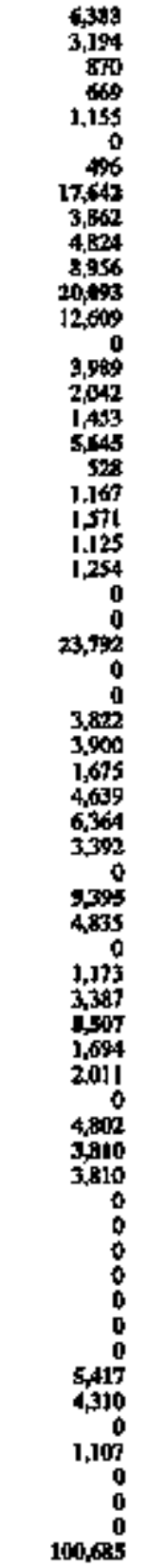 & 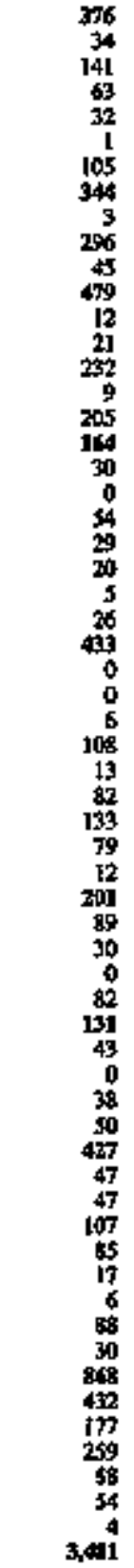 & 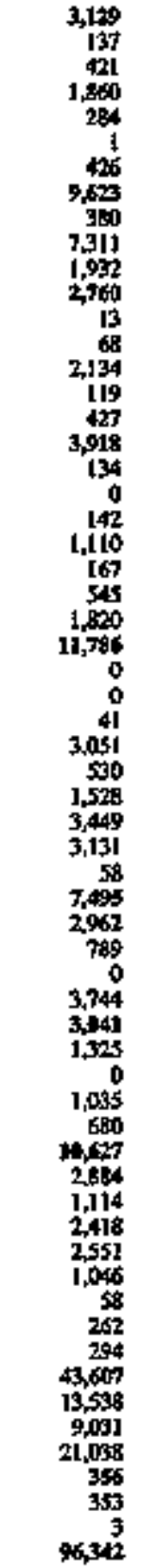 & $\begin{array}{r}14 \\
2 \\
1 \\
8 \\
0 \\
0 \\
3 \\
0 \\
0 \\
0 \\
0 \\
9 \\
0 \\
0 \\
0 \\
3 \\
6 \\
11 \\
1 \\
0 \\
10 \\
0 \\
0 \\
0 \\
0 \\
3 \\
0 \\
0 \\
0 \\
3 \\
3 \\
0 \\
0 \\
0 \\
0 \\
0 \\
0 \\
0 \\
3 \\
0 \\
0 \\
0 \\
0 \\
0 \\
0 \\
0 \\
0 \\
1 \\
0 \\
0 \\
0 \\
0 \\
0 \\
0 \\
0 \\
0 \\
0 \\
0 \\
0 \\
0 \\
0 \\
0 \\
0 \\
0 \\
0 \\
0\end{array}$ & 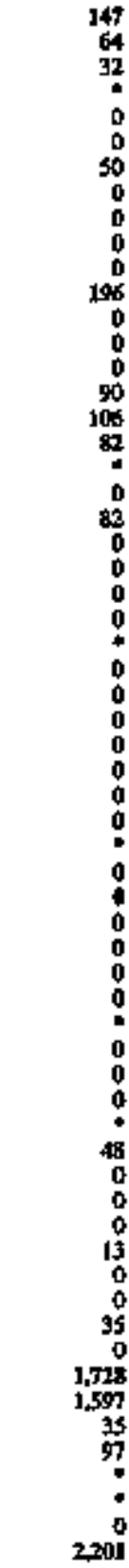 \\
\hline
\end{tabular}

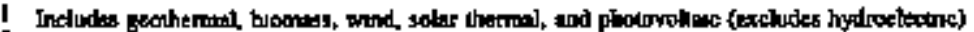

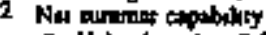
- = Value las then os

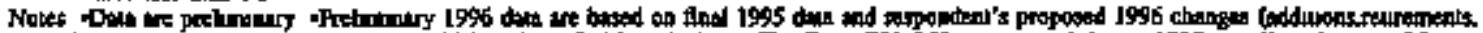

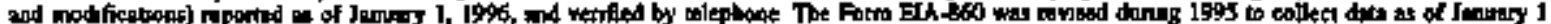

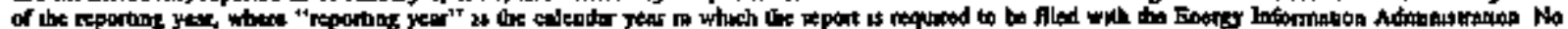

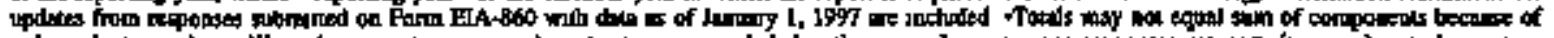

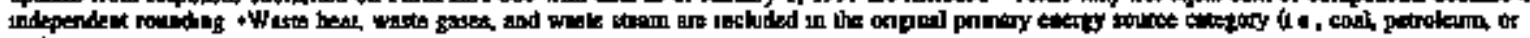
(4))

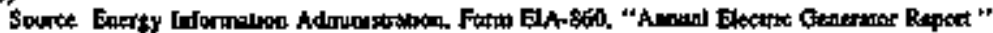


Table 6. Petroleum, Gas-, and Dual-Fired Steam Generating Capability at U.S. Electric Utilities by Census Division and State, 1996

\begin{tabular}{|c|c|c|c|c|c|c|c|c|}
\hline \multirow{2}{*}{$\begin{array}{c}\text { Cenfos Diwblon } \\
\text { Silte }\end{array}$} & \multicolumn{2}{|c|}{ Petruberm } & \multicolumn{2}{|c|}{ Grs } & \multicolumn{2}{|c|}{$\begin{array}{l}\text { DugdFTred } \\
\text { PetraleindGat }\end{array}$} & \multicolumn{2}{|c|}{$\begin{array}{c}\text { Total } \\
\text { Peirolturn and Ges }\end{array}$} \\
\hline & $\begin{array}{l}\text { Mumbur of } \\
\text { Gemeralon }\end{array}$ & $\begin{array}{l}\text { Capabitity } \\
\text { (picfiwatos) }\end{array}$ & $\begin{array}{l}\text { Namber of } \\
\text { Ginarators }\end{array}$ & $\begin{array}{l}\text { Capabinty } \\
\text { (pequingtas) }\end{array}$ & $\begin{array}{l}\text { Nunber of } \\
\text { Generatocy }\end{array}$ & $\begin{array}{l}\text { Capolbitity l } \\
\text { (atepowitl) }\end{array}$ & $\begin{array}{l}\text { Chmber of } \\
\text { Ceneralary }\end{array}$ & 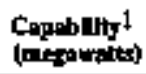 \\
\hline 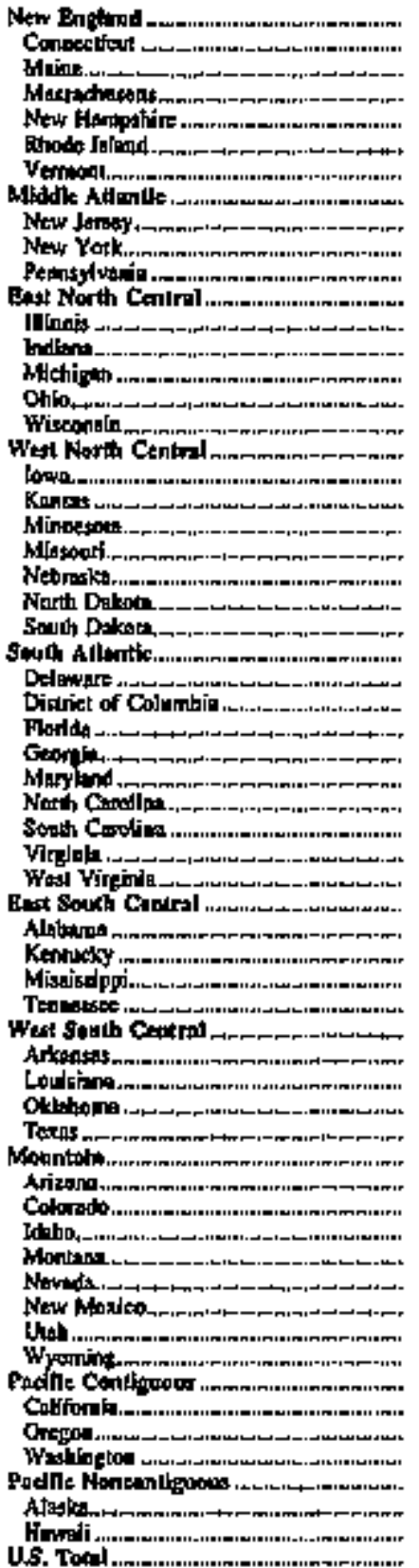 & 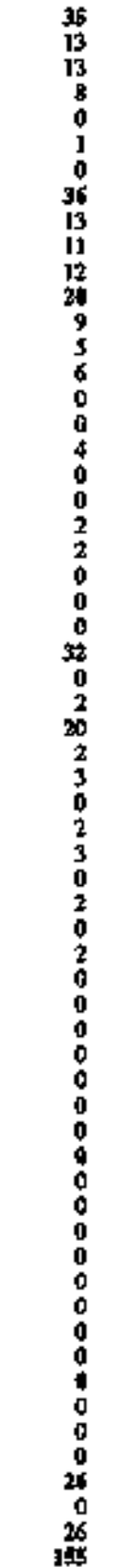 & 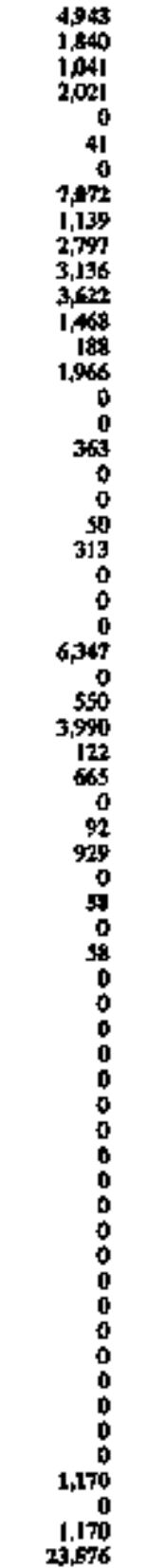 & 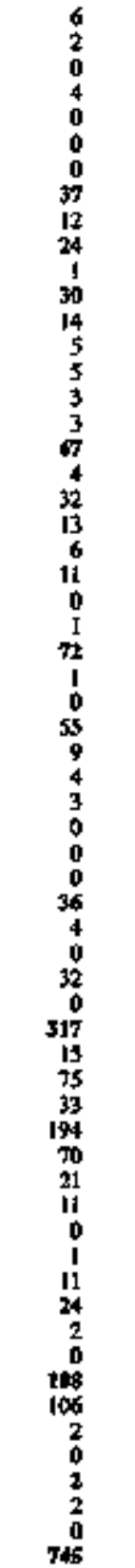 & 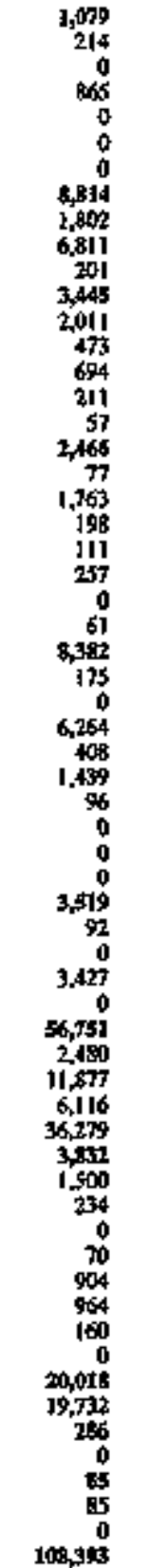 & $\begin{array}{r}16 \\
2 \\
0 \\
13 \\
1 \\
2 \\
0 \\
17 \\
1 \\
10 \\
1 \\
7 \\
6 \\
0 \\
1 \\
0 \\
0 \\
6 \\
3 \\
3 \\
0 \\
0 \\
0 \\
0 \\
0 \\
0 \\
0 \\
0 \\
0 \\
0 \\
0 \\
0 \\
0 \\
0 \\
0 \\
0 \\
0 \\
0 \\
0 \\
0 \\
0 \\
0 \\
0 \\
0 \\
0 \\
0 \\
0 \\
0 \\
0 \\
0 \\
0 \\
0 \\
0 \\
0 \\
0\end{array}$ & 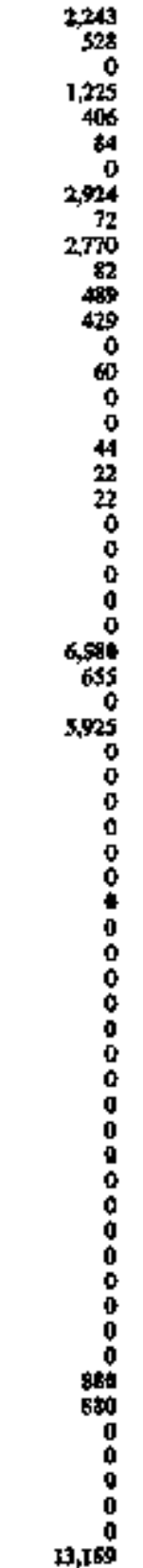 & 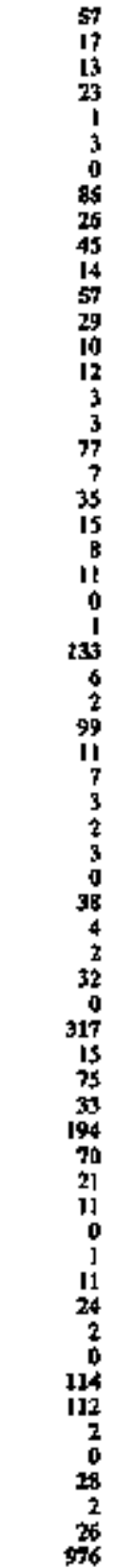 & 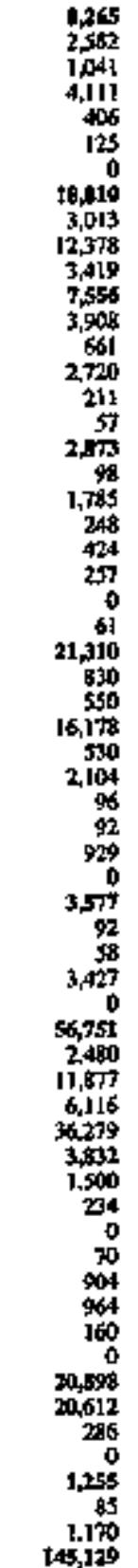 \\
\hline
\end{tabular}

I Nel sumenter copectiliny.

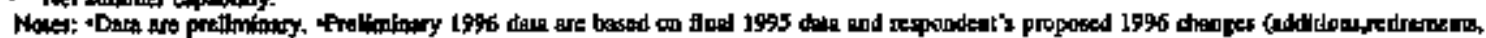

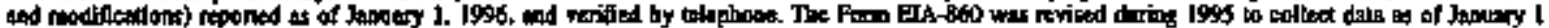

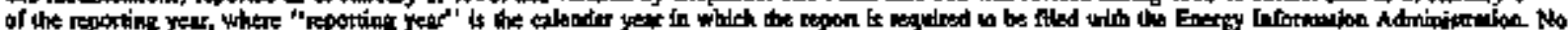

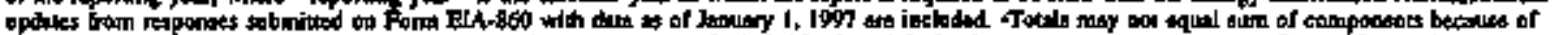

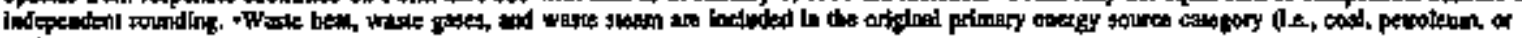
gris)

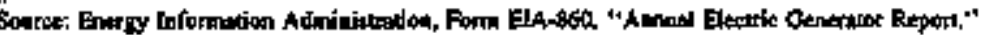


Table 7. Petrolenm-, Gas-, and Doal-Fired Gas Turbine/Internal Combostion Generating Capability at U.S. Electric Utilities by Census Division and State, 1996

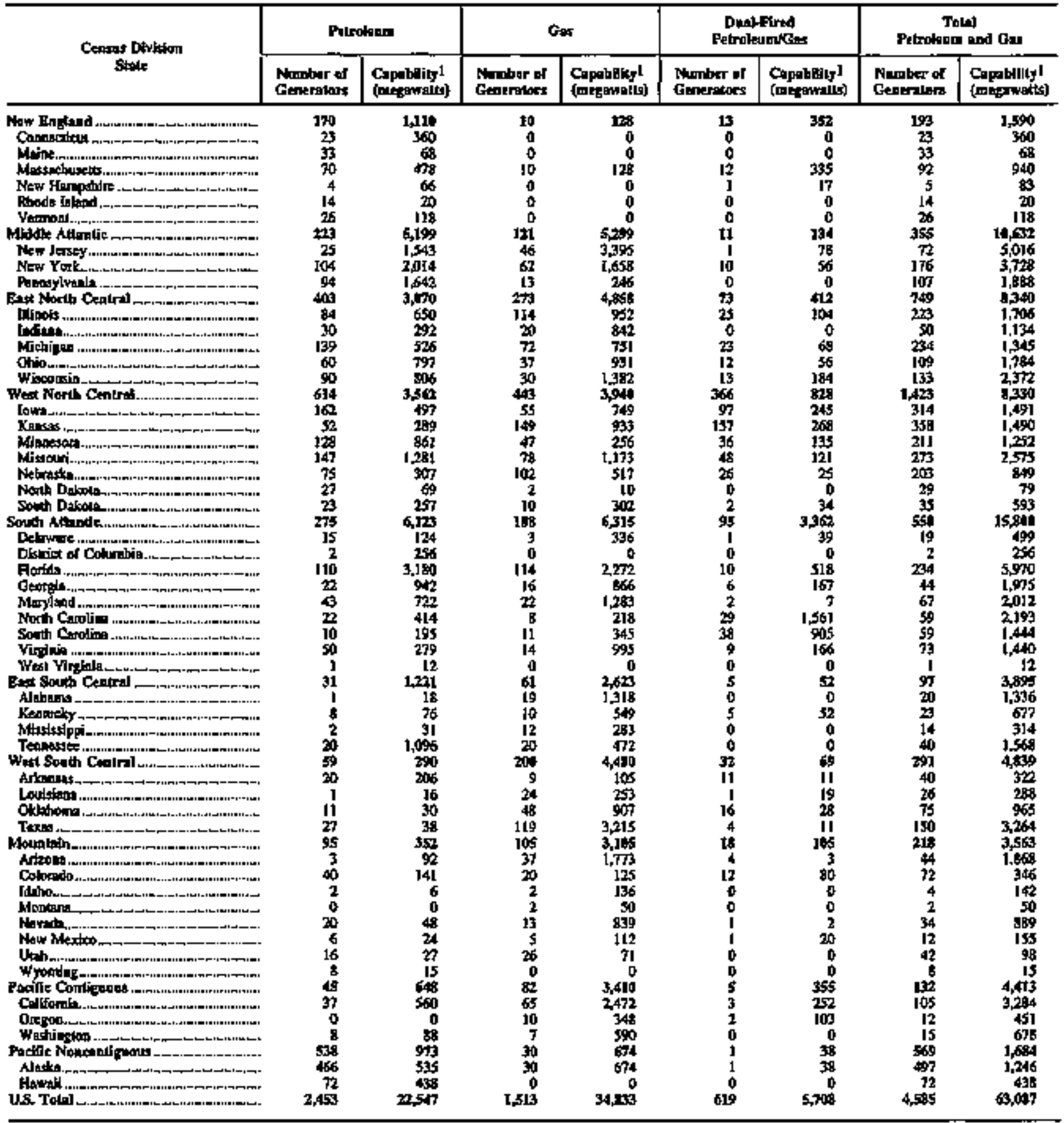

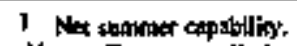

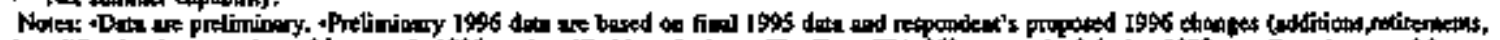

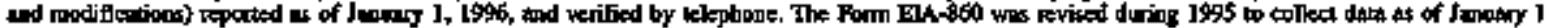

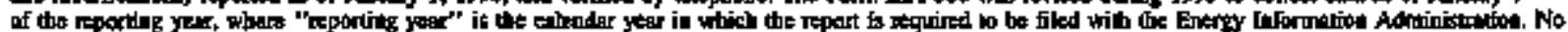

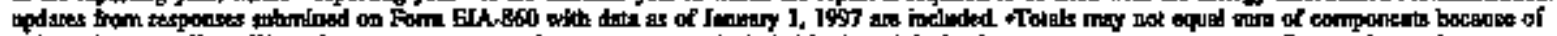

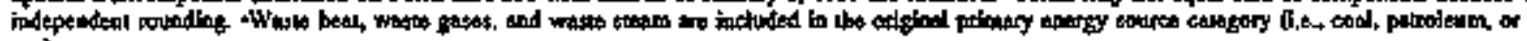
7ns).

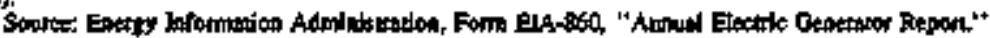




\section{Net Generation from U.S. Electric Utilitles}

This chapter provides summary statistics on the amount of electrictity produced by electric utiltties in the United States. The different energy sources used by electric utilities to produce electric power are also discussed in this chapter.

The production of electritity is generally referred to as generation and is measured in kilowatthours. Gross generation is the amount of power produced by an electric power plant (station), measured at the terminals of the plant (that is, prior to the point at which the power leaves the station and is available to the system). Some of the electric power generated at a power plant is used to operate equipment at the plant. Power used at the plant generally ranges between 1 percent (for hydroelectric units) and 7 percent (for steam-electric units). Net generation is the power avallable to the system (gross generation less use at the plant); however, it is greater than that avallable to consumers due to losses during transmission and distribution (approximately $B$ percent to 9 percent). Netgeneration is the measure used for electric power production by electric utilities in this report.

\section{Generation from Fossil Fuels}

Coal. Historically, most generation of electricity in the United States has been from coal. Coal-fired generation became even more impottant following the Arab oil embargo of 1973 due to concerns over the availability of petroleum imports, increasing petroleum costs, and curtailments of natural gas. In 1978, the passage of the Powerplant and Industrial Fuel Use Act and the Natural Gas Policy Act encouraged further use of coal by electric utilities. Although both Federal and State envtronmental laws and regulations existed during the 1970's, renewed interest in environmental issues raised concerns about electric power plant emissions, particularly from those plants buring coal. The Clean Air Act Amendments of 1990 established a goal of a 10-million-ton reduction in sulfur dioxide emissions and a 2-nillion-ton reduction in nitrogen oxide emissions by 2000 from 1980 levels. Coal-fired generation continues to provide more than one-half the total net generation of electricity by electric utilities in the Nation. Most of the electricity production from coal by electric uttities occurs in the East North Central and South Atlantic Census Divisions where substantial amounts of coal are mined.

Petrolenm. During the early $197 \%$, electric utilities used petroleum extensively to generate electricity. However, after the 1973 embargo by the Organization of Petroleum Exporting Countries (OPEC) on petroletum exports to the Untted States, petroleum prices rose sharply. Futther price increases occurred in 1979 and 1980 following the Iranian revolution and subsequent reductions in Iranian petroleum exports. Consequently during the past decade, utilities have not built large, petroleum-fired steam units. In addition, many utillties have either converted steam units to coal or switched fuels where duat-fled capability exists. Most of the utitities that still rely heavily on petroleum to generate electricity are located along the eastem seaboand.

Gas. The demand for gas (primarily natural gas) to heat homes and serve business and industry has historically taken prtority over demand from electric utilities under both Federal and State regulations. In the 1970's, many utilities were on occaston denied gas when available pipelines reached capacity in serving heating demand during the months from November to March (the peak heating season). By the middle 1970's, curtailments to electric utilities also occasionally occurred during the nonheating season as producers conserved supply in preparation for heating season demand. In the face of an attractive interstate price struchure, but deprived of supplies during many months of the year, utilities in the 1970 's used relatively less expensive gas when it was available, then switched to other more expensive fuels when gas supplies were curtalled. Gas became Inore available to utilities with the passage of the Natural Gas Policy Act of 1978 and more frequent exemptions from the gas-use restrictions of the Powerplant and Industrial Fuel Uste Act (Fuel Use Act) of 1978. Amendments to the Fuel Use Act in 1967 created potential for additional use of gas. These amendments eased restrictions on the use of gas by removing a legal requirement to obtain an exemption for the construction of new gas-fired generating capability. The West South Central Census Division, where most of the gas production in the Nation occurs, supplies more than half of the gas-fired generation in the country.

\section{Nuclear-Powered Generation}

Generation from nuclear power has generally increased stince the 1950's, and this trend continues. Since 1984, nuclear plants have provided the second largest share of total U.S. generation of electricity, after coal-fired plants. Although no new nuclear units have been ordered since 1978 and units ordered after 1974 were not built, many units that were under construction have either been 
completed and entered service or will enfer service in the near future. Licensing delays, questions about radioactive waste disposal, and concern about nuclear plant safety have slowed these units from entering service and are still major obstacles to additional growth in the use of this energy source for generating electrictity. Most of the nuclear-powered genteration comes from the Middle Atlantic, East North Central, and South Atlantic Census Divisions (where over 60 percent of the nuclear units in the country are located).

\section{Generation from Renewable Fuels}

Hydroelectric. Water is currently the leading renewable energy source used by electric utilities to generate electric power. Hydroelectric plants operate where suitable waterways are available; many of the best of these sites have already been developed. Generating electricity using water has several advantages. The major advantage is that water, a renewable resource, is a source of cheap power. In addition, because there is no fuel combustion, there is little air pollution in comparison with fossil fuel plants and limited thermal pollution compared with nuclear plants. Like other energy sources, the use of water for generation has linitations, including environmenta! impacts caused by damming rivers and streams, which affects the habitats of the local plant, fish, and arimal life. Seventy percent of the hydroelectric power in the United States is generated in the Pacific and Rocky Mountain States.
Other Sources. Other renewable resources-geothermal (heat energy beneath the strrface of the earth), wood, waste, wind, and the sun (solar)-are energy sources that are constantly replenished. These energy sources have received increased attention in recent years, but a limited number of such generating facilities are in use today. Currently, renewable resources (other than water) supply less than 1 percent of the electricity generated by electric utilities. Most of the electricity produced from this category is from geothermal power. Electric utilities currently operate geothermal plants in two States (California and Utah). The Geysens, operated by the Paciftc Gas and Electric Company, is the Iargest geothermal plant in the Nation. Only a few utilities operate units that produce electricity from wind and solar energy. Wood and waste resources can be used to replace fossil fuels in utility boilers. To date, just a few electric generating units have been built that use wood or waste products as a primingy futel.

\section{Data Sources}

The data in the following tables are aggregated at national, regional, and State levels for the period 1992 through 1996. Data in the tables were obtained from the Form ELA-759, "Monthly Power Plant Reportr" which is used to collect monthly data from all operators of electric utiltites (apptoximately 700) in the Undted States. More detailed statistics from the Form BLA-759 are published in the Electric Poner Monthily. ${ }^{16}$

Table 8. Net Generation from U.S. Electric Utiltties by Energy Source, 1992 Through 1996 (Million Kilowathiours)

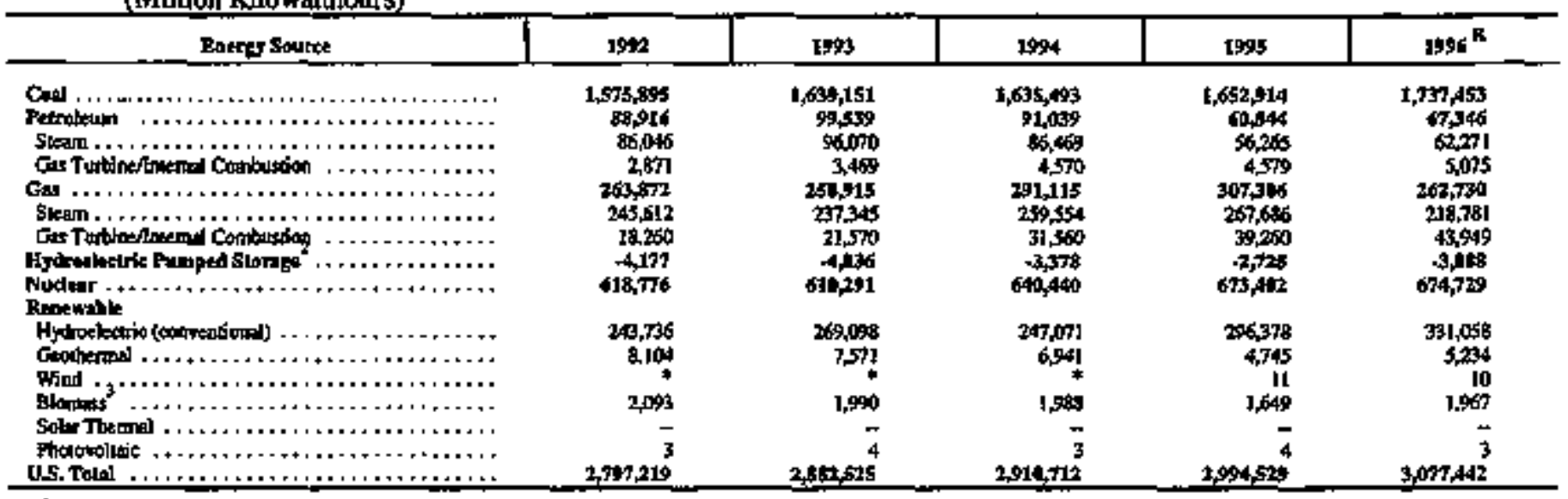

Includes potrokum mols.

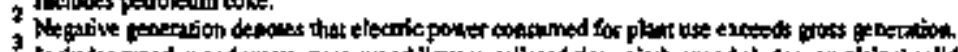

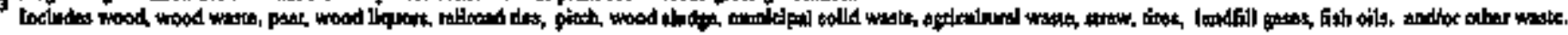

- Villack kst lion 0.5

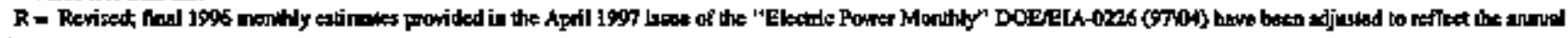
Medrs.

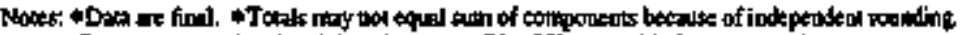

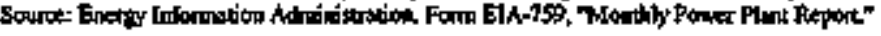

16 Encrgy Enformation Administration, Electric Power Monthiy, DOEELA-0226. 
Table 9. Net Generation from U.S. Blectric Utilities by Selected Prime Mover, Census Divtsion, and State, 1995 and 1996

(Mitlion Kilowatthours)

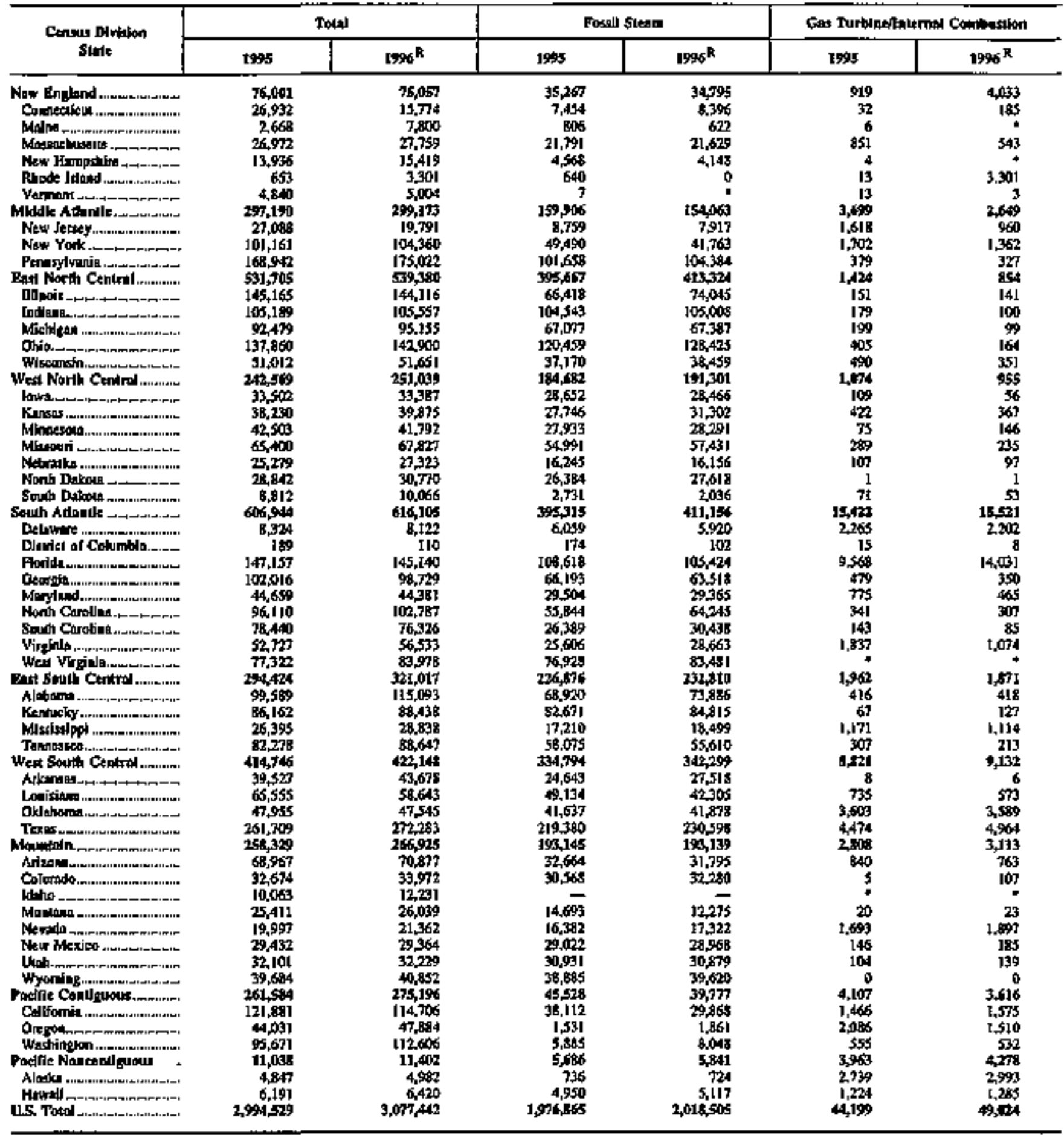

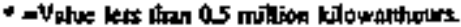

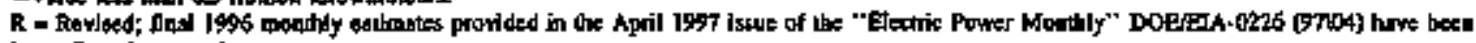

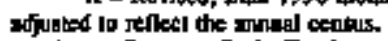

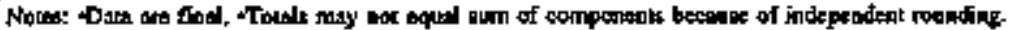

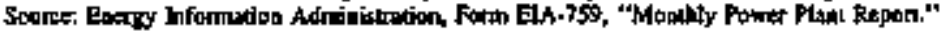


Table 10. Net Generation from U.S. Electric Utilitles by Energy Source, Census Division, and State, 1995 and 1996

(Million Kilowathours)

\begin{tabular}{|c|c|c|c|c|c|c|}
\hline \multirow{2}{*}{$\begin{array}{c}\text { Cunsus Dlrision } \\
\text { stole }\end{array}$} & \multicolumn{2}{|c|}{ Cooll } & \multicolumn{2}{|c|}{ Petrolienal } & \multicolumn{2}{|c|}{$\mathrm{Gras}$} \\
\hline & 1995 & $1996^{R}$ & J995 & $19 \$ 0^{R}$ & 1995 & $1996^{R}$ \\
\hline 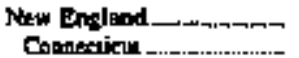 & $\frac{16,203}{2760}$ & 13,312 & 11,126 & $13,0,02$ & 8,637 & 8,648 \\
\hline 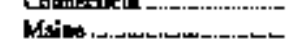 & $\frac{4208}{-}$ & $\frac{2,168}{-}$ & $\begin{array}{r}3,3 \% 7 \\
812\end{array}$ & $\begin{array}{r}5,255 \\
622\end{array}$ & 1,820 & 959 \\
\hline Masuaghussols ..._-_-_- & 10,587 & IIs:5l & 5,849 & $6,2,1$ & $6, \overline{206}$ & $4 \overline{150}$ \\
\hline 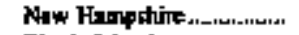 & $3,36 \mathrm{f}$ & 3,310 & $\mathrm{I}, \mathrm{OCH}$ & 838 & 201 & 4,450 \\
\hline Rhode ]tpond ..................... & - & - & 50 & 62 & $\operatorname{sos}$ & 3,239 \\
\hline 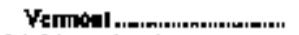 & - & - & 13 & 3 & $y$ & 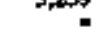 \\
\hline 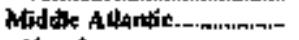 & 221,9016 & 127,129 & 11,762 & 13,148 & 20,06s & 16,436 \\
\hline Net & 5.105 & $\$ \$ 26$ & 885 & 611 & 4,396 & 2,439 \\
\hline New York & 19,949 & 20,444 & 7,835 & 9.325 & 23,414 & 13,355 \\
\hline Panncyltanis & 96, sto & 100858 & 3,072 & 3,213 & 2,165 & 641 \\
\hline Enat Narth Centras & $38+4,842$ & 408,296 & 2134 & 2,16 & 6,014 & 3,723 \\
\hline Wlloodg .._-_-_-_-_-_-_.. & 62,736 & 71,515 & 888 & 795 & 2,944 &, \pm 873 \\
\hline 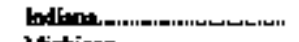 & 103,775 & 104,414 & 213 & 321 & 734 & 974 \\
\hline 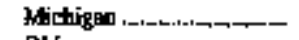 & 65425 & 66,007 & $6 \$ 7$ & 652 & 1,16 & 737 \\
\hline 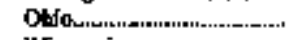 & 120,443 & 128,125 & 298 & 267 & sta & 196 \\
\hline 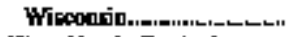 & 36,864 & 38,145 & \pm 47 & 124 & 649 & 540 \\
\hline Werl Noxth Certral._-_-.. & 179,803 & 12:,13] & 1,392 & 1,154 & 4,50 & 3,661 \\
\hline | & 28,426 & 28,283 & $\$ \$$ & $\mathbf{5 l}$ & $m$ & 189 \\
\hline 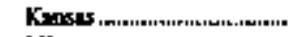 & 25,897 & 29,743 & 74 & Is & 2,198 & 1,768 \\
\hline 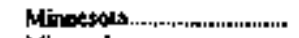 & 26821 & 27,329 & 485 & 640 & $\pi 03$ & 468 \\
\hline 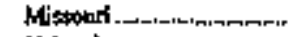 & $5,5,582$ & 57.176 & 682 & 96 & 1,015 & 395 \\
\hline 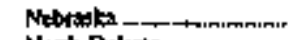 & $16,0,000$ & |6,04| & 27 & 20 & 245 & 192 \\
\hline Nonh Dakota ....t.-_-_... & 26,336 & 27,500 & 49 & 89 & -1 & 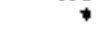 \\
\hline Souch Dilotata ................. & 2,721 & 2030 & 17 & 9 & 63 & s0 \\
\hline 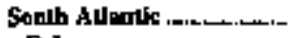 & 341,974 & 366,611 & 15,596 & 27,164 & 4,967 & $35,9,5$ \\
\hline 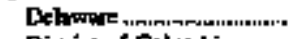 & 4,222 & 4,275 & 917 & I,188 & 3,180 & $2, \pi 0 \%$ \\
\hline District of Coltembia...m.... & - & - & 189 & 110 & - & - \\
\hline Florida & 61,864 & 65,782 & 21,5883 & 22,91 & 34,738 & $30,78]$ \\
\hline 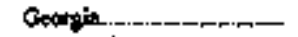 & 65,880 & 63,231 & 215 & 292 & 573 & 345 \\
\hline 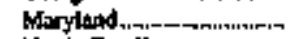 & 27.370 & 27,780 & 1,4008 & 1,401 & 1,501 & $6 * 9$ \\
\hline Nanh Cunblas. & 5,898 & 64,018 & $\mathbf{I} 4$ & 259 & 253 & Iss \\
\hline Soub Cmollod & 15,2002 & 30,307 & 130 & 126 & 600 & 90 \\
\hline Virod da_aーー・エーーーー & 24443 & 27,930 & 1,120 & 683 & 1,881 & 1,124 \\
\hline West Vrginib_-_..........- & 76,690 & 83,251 & 197 & 204 & 40 & 20 \\
\hline Ras! Sull Centres........... & 218,325 & 205175 & \$*9 & $\pi, 7+2$ & 10,105 & 7,116 \\
\hline Ablomy & 68,553 & 73,599 & 102 & 136 & 600 & 349 \\
\hline Xatucky, ..., & 92,539 & 84,660 & $13 t$ & 135 & 68 & 146 \\
\hline 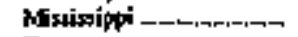 & 9,260 & 12,010 & 24 & 0,174 & 9,098 & 6,430 \\
\hline Tenansten-_-_, & $\$ 7,972$ & 55304 & 253 & 248 & 158 & 61 \\
\hline Wet Soulh Cencrol ........ & 192,324 & 208,104 & 383 & $1, \mathbf{T S}$ & $150,90 \%$ & $10+2,2$ \\
\hline 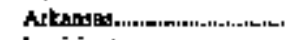 & 21,506 & 24,339 & $\$ 3$ & 98 & 3,092 & 3,097 \\
\hline 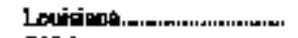 & 15,954 & 18,633 & 49 & $2+3$ & 90,667 & 23,972 \\
\hline 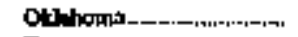 & 25,314 & 31.877 & $7 \mathbf{8}$ & 125 & 15,448 & 13.465 \\
\hline 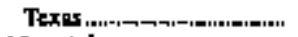 & 122,149 & 133,253 & 209 & $\$ 59$ & 101,501 & 101.746 \\
\hline Moontwin...-_-_rur.m..... & 185400 & 11:5,234 & 250 & 36 & 9,943 & 4713 \\
\hline 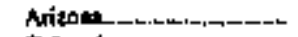 & 31,310 & 30,781 & 64 & 65 & 1.720 & 1,712 \\
\hline 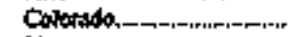 & 30,276 & 31.952 & 20 & 16 & 287 & 419 \\
\hline btho ............................... & - & - & $\star$ & $*$ & - & - \\
\hline Mandana & 14,656 & 12,242 & 23 & 18 & 32 & $3 B$ \\
\hline Pluda & 13.972 & 1467 & 27 & 94 & 4.077 & 4,A5B \\
\hline Now Maxleo ..._............. & 26,121 & 26,357 & 23 & 22 & 3,023 & 2,773 \\
\hline 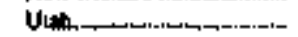 & 30,260 & 30,693 & 34 & 31 & 741 & 293 \\
\hline Wyording _..._-_-_.-_-_ & 38.806 & 39,552 & $6 B$ & 39 & 13 & 9 \\
\hline Poclife Conthoons........... & 3,405 & 9,770 & 512 & 69 & 41,724 & 32,94 \\
\hline 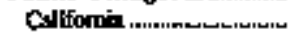 & - & - & $4 B 9$ & 675 & 39,090 & 30,768 \\
\hline Dregonn.............................. & 1.520 & 1,728 & 4 & 7 & 2,084 & 1.637 \\
\hline Weshinglon רחרו........., & 5,67 & 8,042 & 9 & 8 & 554 & 529 \\
\hline Pactite Nenconlitiagats + & Ith & 209 & 6,661 & 7,446 & 2,679 & 2,944 \\
\hline 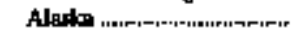 & 309 & 29 & 487 & 643 & 2,679 & 2844 \\
\hline 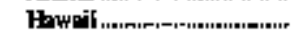 & - & - & 6,175 & 6,402 & - & - \\
\hline 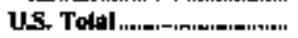 & $1,653, \$ 14$ & L,TS, 453 & 60,844 & 67,346 & 307,346 & 26,730 \\
\hline
\end{tabular}

See nowas and foobrotes at and of loble. 
Table 10. Net Generation from U.S. Elentric Utilities by Epergy Source, Censons Division, and State, 1995 and 1996 (Continued)

(Million Kilowatthotirs)

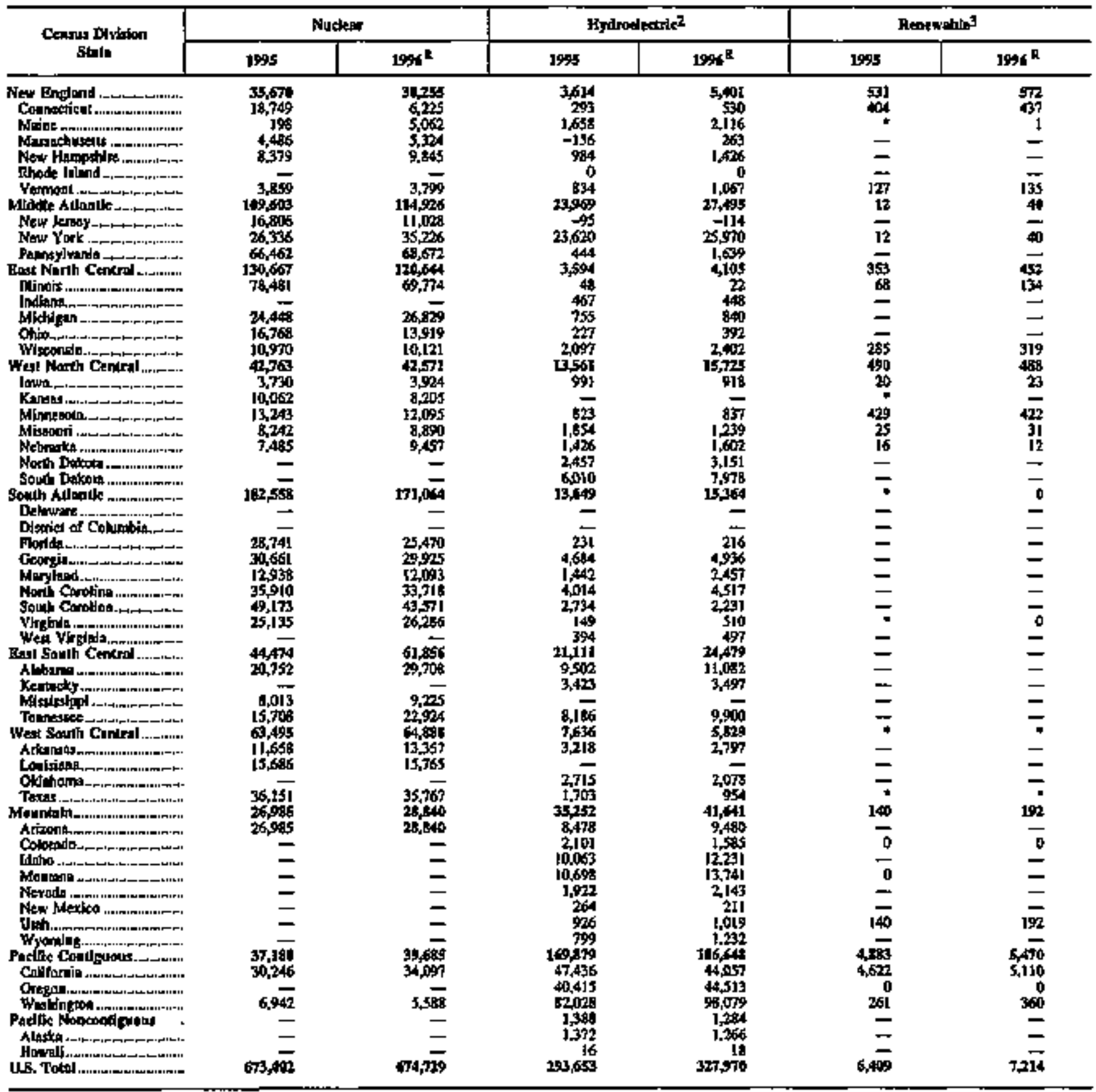

I Inchudes potrolem tokt.

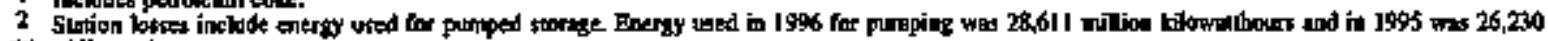

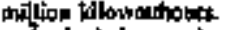

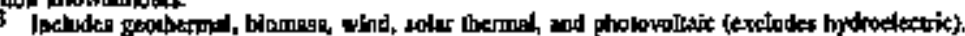

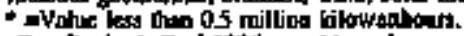

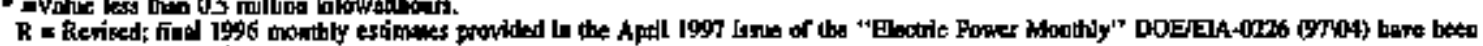

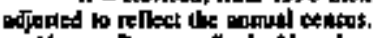

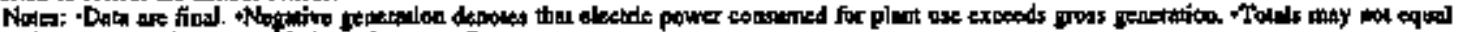

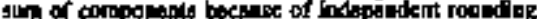

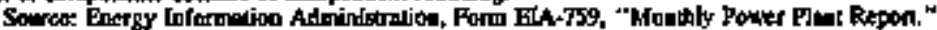


Tahle 11. Petralenm-Fired Net Generation from U.S. Flectrtc Uttlities by Selected Prime Morer, Census Division, and State, 1995 and 1996

(Million Kilowatthours)

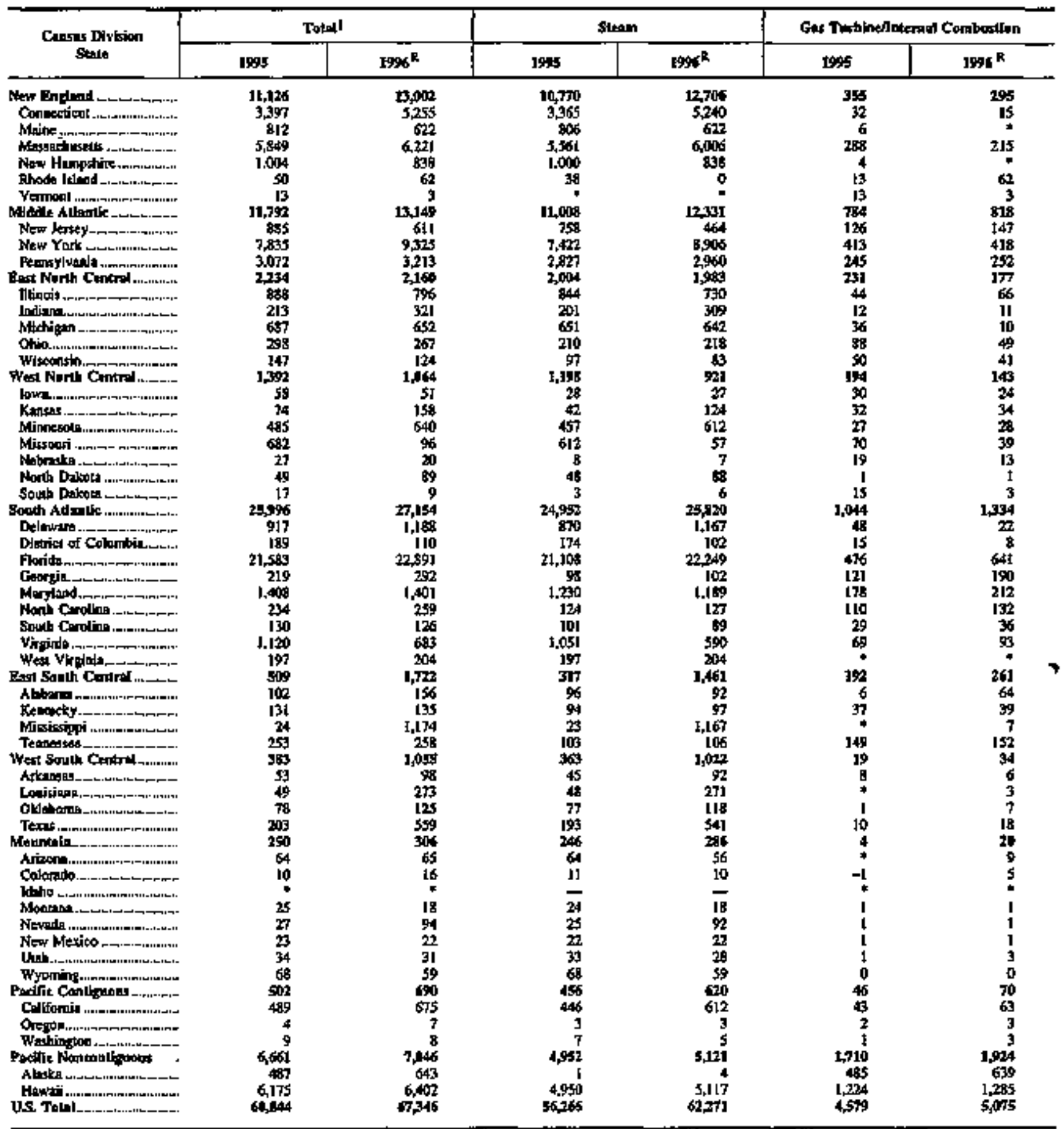

1 lastodes potraluint cotat

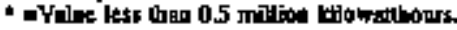

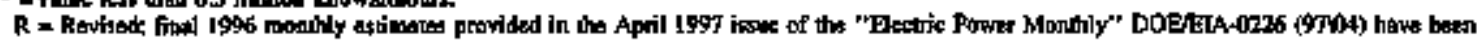

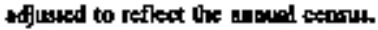

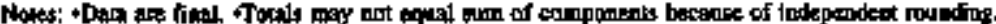

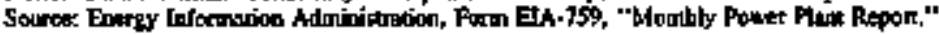


Talole 12. Gas-Fired Net Generntion from U.S. Electric Utiltiles by Selected Prime Mover, Census Division, and State, 1995 and 1996 (Milion Kilowatthours)

\begin{tabular}{|c|c|c|c|c|c|c|}
\hline \multirow{2}{*}{$\begin{array}{c}\text { Canru Dustation } \\
\text { givla }\end{array}$} & \multicolumn{2}{|c|}{ Total } & \multicolumn{2}{|c|}{ Stean } & \multicolumn{2}{|c|}{ Ges Turbinefinlemal Combuation } \\
\hline & 1995 & $199 \mathrm{x}^{\mathrm{R}}$ & $19 \%$ & $1994^{2}$ & 19 is & $19966^{R}$ \\
\hline 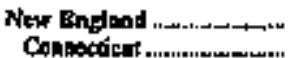 & $\begin{array}{l}8,237 \\
1,4,20\end{array}$ & 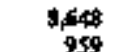 & 9,273 & 4,711 & 564 & 3,737 \\
\hline 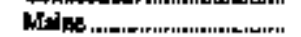 & - & - & $=$ & - & - & - \\
\hline 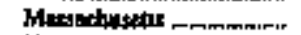 & 6,206 & 4,450 & 5,643 & 4,122 & 563 & 328 \\
\hline 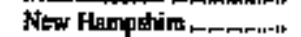 & 201 & & 201 & 0 & I & + \\
\hline 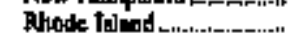 & 603 & 3.219 & 603 & 0 & - & 3.239 \\
\hline Ventonl ............................ & & & 7 & $*$ & - & - \\
\hline 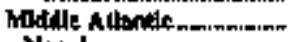 & 29,45 & 16416 & 27,051 & 14,604 & 2,915 & 1851 \\
\hline Now lersey.........._-_... & $\begin{array}{r}4,386 \\
23, \$ 14\end{array}$ & 2,439 & 2895 & 1,626 & 1.491 & 813 \\
\hline 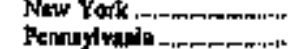 & $\begin{array}{r}23.414 \\
2,165\end{array}$ & $\begin{array}{r}13,353 \\
643\end{array}$ & $\begin{array}{r}22124 \\
2,031\end{array}$ & $\begin{array}{r}12,412 \\
586\end{array}$ & $\begin{array}{l}1,290 \\
134\end{array}$ & $\begin{array}{r}943 \\
75\end{array}$ \\
\hline Eued Norll Centrod & 6,0114 & 3,313 & 4,21 & 3,046 & 1,195 & 67 \\
\hline bHinds & 2,944 & 1,555 & 2,838 & 1 tots & 106 & 75 \\
\hline 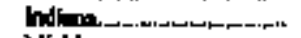 & 734 & 374 & 567 & 285 & 167 & 89 \\
\hline 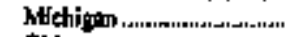 & 1.169 & 737 & 1,001 & 648 & 163 & s \\
\hline Otro,-mm-n & sh & 196 & 206 & 81 & 318 & IIs \\
\hline 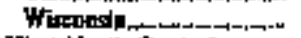 & 649 & 540 & 210 & 231 & 439 & 310 \\
\hline Wefi Nocth Contral. & 4,500 & 3,01 & $3,6,21$ & 2,249 & s:o & 817 \\
\hline low: & $\mathbf{2} \boldsymbol{T}$ & 189 & $19 \%$ & 157 & 79 & 32 \\
\hline 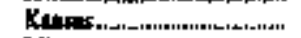 & 2,198 & 1,768 & 1.807 & 1,435 & 300 & 333 \\
\hline 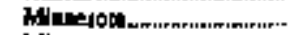 & 700 & 468 & 655 & 390 & d7 & 117 \\
\hline Hisso: & 1,015 & 395 & in & 199 & 219 & 196 \\
\hline Nebrakd & 245 & 192 & 157 & 106 & 站 & $\$$ \\
\hline Noth Dakoth & -1 & 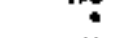 & -1 & 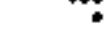 & 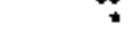 & 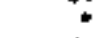 \\
\hline South Dakpt . & 63 & 50 & 7 & $\bullet$ & 56 & 50 \\
\hline Soutio Atlantic.............. & 42,767 & 36913 & 28 & 12,725 & $143 \pi$ & 15,157 \\
\hline Delqupte & 3.180 & 2,708 & 963 & 52 & 2,217 & 2,180 \\
\hline Didtiet of Coluabina...... & - & - & - & - & - & - \\
\hline Flotidh & 34,738 & $30.7 \$ 1$ & 25.645 & 17,392 & 9.092 & 13,390 \\
\hline Goorgtam & S75 & 345 & 215 & 184 & 358 & 161 \\
\hline 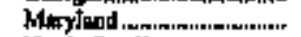 & $I, 5001$ & 649 & 904 & 396 & 597 & 252 \\
\hline 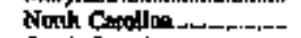 & 253 & 195 & $2 k$ & 20 & 231 & 175 \\
\hline Sowh Corrition................ & 600 & 90 & 487 & 42 & 114 & 49 \\
\hline Vitginin & 1,281 & 1,124 & 113 & 143 & 1,768 & 981 \\
\hline West Yrgenil..... & 40 & 20 & 40 & 20 & - & - \\
\hline Eost South Ceninal & 10,0), & 7,186 & $8,2,15$ & 5,576 & 1,770 & 1,61* \\
\hline 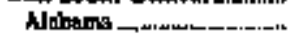 & 680 & 549 & 1? & 195 & 410 & 354 \\
\hline 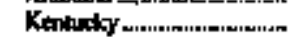 & 68 & 146 & 97 & 58 & 31 & 88 \\
\hline 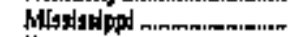 & $9.00 \%$ & 6.430 & 1.927 & 537 & 1.17 & 1.107 \\
\hline Teomerset._._. & 159 & $6 \$$ & 0 & 0 & 155 & 51 \\
\hline West South Cortutal....... & 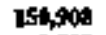 & 142,272 & 140,166 & 133,114 & $g, \sin$ & 9,000 \\
\hline Arkennas: & 3,092 & 3,057 & 3,002 & 3,087 & + & 0 \\
\hline 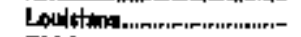 & 30,867 & 23,972 & 30.132 & $\mathbf{2}, \mathbf{M 0 2}$ & 735 & 571 \\
\hline 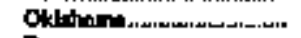 & 15,448 & 13,465 & 11,846 & 9,983 & 3,602 & 3,552 \\
\hline 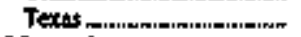 & 101.501 & 101,748 & 97,097 & 94.802 & 4,465 & 4946 \\
\hline Mfandale_,_....._._-_... & 9,500 & 5,713 & $70 \%$ & 6,619 & 2804 & $3,0,3$ \\
\hline 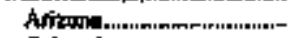 & 1,729 & 1,712 & 890 & 958 & 840 & $7 \$ 4$ \\
\hline 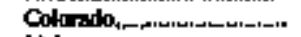 & 257 & 419 & $2 \$ 1$ & 318 & 6 & 101 \\
\hline 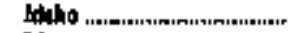 & - & - & - & - & - & - \\
\hline Montune & 37 & 38 & 13 & 16 & 19 & 23 \\
\hline 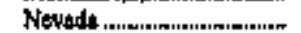 & $4,07)$ & 4468 & 2.795 & 2,573 & 1,691 & 1.896 \\
\hline Str Mexilco ___-_-_- & 3,023 & 2,773 & 2879 & 2,590 & 145 & 184 \\
\hline 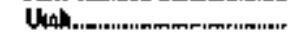 & 741 & 295 & 638 & 157 & 103 & 137 \\
\hline 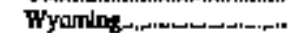 & 13 & 9 & 13 & 9 & - & - \\
\hline 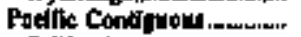 & 41,2 & 32534 & 37,667 & 29,315 & 4,051 & 3,547 \\
\hline Gallorald & 39090 & 30,768 & 37,666 & 29,267 & 1,423 & 1,312 \\
\hline 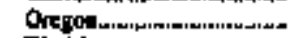 & 2,084 & 1.637 & 0 & 130 & 2,004 & 1,507 \\
\hline Watipiot mmmn.......... & 554 & 529 & $\mathbf{1}$ & । & 534 & 528 \\
\hline Pudne Nonconlfguras . & 2,679 & 2,644 & 415 & 40 & 2,254 & 2354 \\
\hline 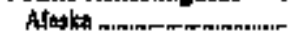 & 2,679 & 2,844 & 425 & 490 & 2254 & 2,354 \\
\hline 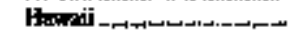 & - & - & - & - & - & - \\
\hline U,s Tolph & 301,316 & 262730 & 267,686 & 218,771 & 39,620 & 43,949 \\
\hline
\end{tabular}

- avatua las than 05 mallito bilowathoura.

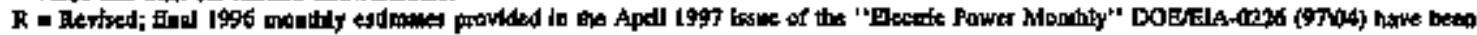

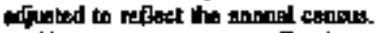

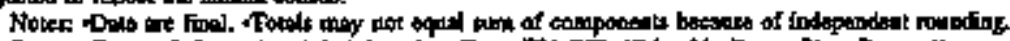

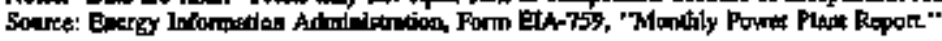


- 525 


\section{U.S. Electric Utility Fossil Fuel Statistics}

This chapter contains statistics on consumption of fossil fuels by U.S. electric utilities to generate electricity, and end-of-year fossil fuel stocks for all U.S. electric utility plants. Statistios are also included for receipts and costs of fossil fuels at power phants with a steam-electric and combined-cycle nameplate capacity of 50 or more megawatts, approximately 86 percent of the total capability at U.S. electric utitites. These data are aggregated to national, Census division, and State levels.

Vartous sources of energy are used by electric uttlities to produce electricity; however, fossil fuels supply about 70 percent of the energy sources for the generation requirements of the Nation. Coal, petroleum, and gas are currently the dominant fossil fuels used by the industry. ${ }^{\text {" }}$ Statistios on consumption, purchases (receipts), and stocks of fossil fuels at electric utiltties are interdependent. That 15 , the stocks on site at the utility at the end of the current year result from the stocks that were available at the end of the prior year, the amount of fuel purchased during the current year, and the amount of fuel consumed during the year.

\section{Fossil Fuel Consumption and Stocks}

Coal the energy source used by electric utfilties to generate more than one-hatf of the electricity needed in the Nation, is consumed extersively throughout the United States (particularly in the East North Central, West North Central, West Soufh Central, and the South Atlantic Census Divistons). The use of petroleum for generation is not as common on a national level as during the early 1970 's, however, some areas of the country (such as in the New England, Middle Atlantic, and South Atlantic Census Dlvtsions) conthue to use it extensively. Consumption of gas occurs mostly in areas of the country where it is readily acossible, particularly in the West South Central Census Division, and in dual-fired generator urits, which use gas and petroleum as substitute fuels.

The purposes of an-site storage are to provide an uninterrupted supply, to allow bulk shipments, and to take advantage of fatorable market conditions. Electric utilites maintain stockpiles of coal and petroleum to minimize the effect of an interruption or curtailment in fuel availability (for example, railroad strikes, coal-mine strikes, or oil embargoes). Since gas is generally not stored, there are no stocks of gas.

\section{Fossil Fuel Receipts and Costs}

Statistics on electric utility recedpts provide information regarding the deitvery of fossil fuels to steam-electric plants. The costs tncluide all costs incurted by an electric utility in the purchase and delivery of fuel to the plant. The type of contract under which a fued is purchased has a sigrificant effect on the cost of the fuel delivered and can be used as a good indicator of market conditions. Transactions where petroleum and coal are obtained by the utility under purchase ordes or contracts with a duration of 1 year or more are referred to as contract purchases. Shtpments of petroleum and coal under purchase orders or contracts of less than 1-year duration are considered spof purchases. Transactions that are conducted under a contract with uninterrupted delivery to secure gas are identified as fimm purchases. Intermoptible purchases are those in which the gas is received under a contract that perrits curtailment of service under certain circemstances. Foc example, under both Federal and State regulations, requirements for gas to heat homes and serve mdustry have priority over requirements of the electric powver industry. Consequently, a contract under which gas is purchased is most generally one that allows for an fnterruption in its accessibility.

Coal. Coal is obtained from thuee major cosl-producing areas in the United States. Appolachion cont is mined in both sunface and underground mines located in Penrsylvaria, Maryland, Virginia, West Virginia, eastem Kentucky, Tennessee, Alabama, and Ohio. This coal is bituminous in rank and of low-to-medium sulfur content. Its heat content in British Thermal Uinuts (Btu) averages over 12,000 Biu per pound. The coal is transported primarily by train, barge, and truck to electric utility plants throughout the Eastern United States. Interior coal is mined in both surface and underground mines located primarily in Illinois, Indiana and westem Kentucky. It is bituminous coal with a hagh percentage of sulfur and contains approximatedy $11,000 \mathrm{Btu}$ per pound. Most of this coal is delivered to plants in the Central and Southeastern United States. Western coal is mined in

17 Other tossil fuels include petrolenm cokce, refinery pas, coke owen gas, blast furnace gas, and Irquefied petroleurn gas. 
Montana, Wyouing, Colorado, Utah, North Dakota, Arizona, and New Mexico. It is delivered to plants throughout the Westem and Centtal United States. Over one-half of the coal in this region is subbitumtrous coal that is low in sulfur content (less than 0.5 percent) and contatns approximately 9,000 Btu per pound. Most of this coal originates in the Powder River basin of northeast Wyoning and southeast Montana. Coal from this region is delivered by unit train to plants as far east as Indiana and Georgia.

The cost of coal delivered to electric utilities can vary significantly from State to State. Coal delivered to the New England Cersus Divtsion from the Appalachian coal fields may cost as much as $\$ 60$ per short ton due to transportation costs and the higher cost of producing eastem coal (generally in underground mires). Environmental restrictions within a State may require electric utilities to burn only the more expensive, low-sulfur coal resulfing in a higher delivered cost. In the West, especiaily in the Mountain Census Division, coal-burring plants are often built dose to the Itine thus reducing transportation cossts. In addition, the cost of mining coal from large surface mines located in the Westem United States is significantly less than that of undergrotmd eastem mines, resulting in a dehvered cost of under $\$ 15$ per short ton for States such as Montana and Wyoring. The cost of coal delivered to electric utilities in States such as North Dakota, South Dakota, and Texas is well below the national average because of the lower cost of low-grade lignite.

Petroleum. Although nationwide receipts at electric utilities are less than one-half the volume of the 1970's, several electric utitities in the New England area, New York, Florida, and Hawaii still depend on petroleum for a significant portion of their fossil fued requirements. Receipts can vary widely from year to year at electric utilities due to changes in the cost of petroleum. Fuel oil numbers 4, 5, and 6 (heavy oil) constitute the mafority of all petrolesum receipts at electric utilities. Smailer amounts of fuel oil number 2 (Itight oil) are also used by electric utilities primarily for start-up and flame stabilization of the boilers.

The cost of petroleum delivered to electroc utilities varies considerably from State to State. The most important factor in determining cost is the type of fuel oil that is being delivered. States receiving orly low-grade heavy oil will show a delivered cost much lower than a State receiving only light oil. Most of the petroleum delivered to the New England, Middle Atlantic, and South Atantic Census Divisions, California, and Hawaii for use by electric utilities is the number 6 fuel oil. The cost of fuet oil can also vary because of its sulfur content Electric utilities that are required to meet stringent environmental standards must purchase low-sulfur fuel oil at preminen prices.

Gas. Gas is tused extensively as a primary fuel throughout areas of the country where it is readily accessible (for example, the West South Central Census Division and in California). Large volumes of gas are aiso transported by pipeline to the Middle Attantic and South Atlantic Census Divisions. Gas receipts in these Census divisions and in Catifornia can vary considerably from year to year because sorre electric utilities switch between use of petroleum and gas in dual-fired generating tunits. The highest volume of gas recelpts at electric utilifies occurs during the summer months when demand for electricity peaks and when there is a greater amount available to electric utilities because of lower demands from residential and commenctal consumers. In some northern parts of the United States, receipts of gas at electric utilities are limited during the winter months due to the putotity for residential heating and industry needs. Many electric utitities have the capability of burning elther petroleum or gas. The cost of the fuel is tusually the determining factor. One major advantage of gas over all other foseil fuels is that it is a clean butring fuel Therefore, some electric utilities use gas in order to comply with environmental regulations.

\section{Data Sources}

Data in the following tables were obtained from two sources. The first is the Form EIA-759, "Monthly Power Plant Report," which is used to collect monthly data from all operators of power plants (approximately 700) in the United States. More detailed statistics on stocks and consumption are published in the Electric Potner Monthity. ${ }^{\text {th }}$ The second source is the Federal Energy Regulatory Commission (FERC) Form 423, "Monthly Report of Cost and Quality of Fuels for Electote Plants," which is a restricted census used to collect data from approximately 230 electric utlities.

1t Entrgy Information Administratma, Electric Powsr Nonthly, DOEELA-0226. 
Caution should be used in comparing stocks, teceipts, and consumption data since all operators of power plants are surveyed by the Form EIA-759, while the FERC Form 423 is limited to operators of power plants with a fossil-fueled steam-electric and combined-cycle nameplate capacity of 50 or more megawatts.

Table 13. Consumption of Fossil Fuels and Year-Eond Stocks of Coal and Petroleum at U.S. Electric Utillties, 1992 Thrangh 1996

\begin{tabular}{|c|c|c|c|c|c|}
\hline Ilen & 199t & t5s & 1994 & 1995 & 1904 \\
\hline 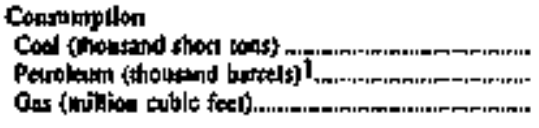 & $\begin{array}{r}79,960 \\
147,335 \\
2765,608\end{array}$ & $\begin{array}{r}813,30,5 \\
1,62,454 \\
2,6,2,44,5\end{array}$ & $\begin{array}{r}517,270 \\
151,004 \\
2,987,146\end{array}$ & $\begin{array}{r}829.007 \\
102.150 \\
3.196 .507\end{array}$ & $\begin{array}{r}374,681 \\
113,274 \\
2,732,107\end{array}$ \\
\hline 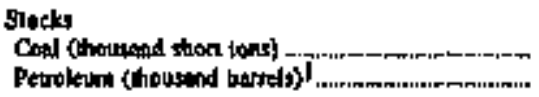 & $\begin{array}{r}154.130 \\
71,819\end{array}$ & $\begin{array}{r}111,341 \\
62,443\end{array}$ & $\begin{array}{r}125,897 \\
62,986\end{array}$ & $\begin{array}{r}126,304 \\
50,405\end{array}$ & $\begin{array}{r}174,623 \\
47,690\end{array}$ \\
\hline
\end{tabular}

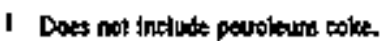

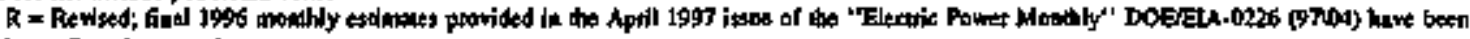
and and is reflect the minual caters.

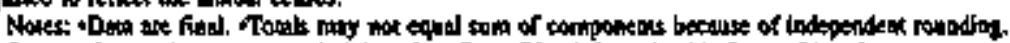

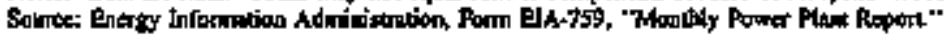

Table 14. Receipts and Average Delivered Cost of Fossil Foels at U.S. Glectric Utilities, 1992 Throngh 1996

\begin{tabular}{|c|c|c|c|c|c|}
\hline Jien & 1592 & 1903 & 1994 & [\%9] & 1906 \\
\hline 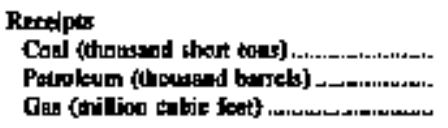 & $\begin{array}{r}75,963 \\
144,396 \\
2,637,675\end{array}$ & $\begin{array}{r}369.152 \\
147,902 \\
2374.523\end{array}$ & $\begin{array}{r}831,929 \\
142,940 \\
2,863,904\end{array}$ & $\begin{array}{r}625,860 \\
84,292 \\
3,023,327\end{array}$ & $\begin{array}{r}362,701 \\
106,629 \\
2,564,663\end{array}$ \\
\hline 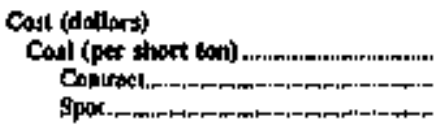 & $\begin{array}{l}2936 \\
2989 \\
2664\end{array}$ & $\begin{array}{l}28.55 \\
28.93 \\
27.19\end{array}$ & $\begin{array}{l}2.6 .83 \\
28.53 \\
2626\end{array}$ & $\begin{array}{l}27,01 \\
2751 \\
2459\end{array}$ & $\begin{array}{l}26.45 \\
26,33 \\
26,97\end{array}$ \\
\hline 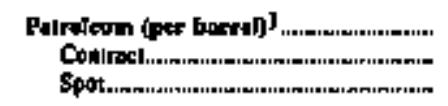 & $\begin{array}{l}16.15 \\
1611 \\
\text { t6.07 }\end{array}$ & $\begin{array}{l}16.42 \\
14.74 \\
14.89\end{array}$ & $\begin{array}{l}\text { I5. } 10 \\
1586 \\
15.48\end{array}$ & $\begin{array}{l}16.93 \\
16.94 \\
16.90\end{array}$ & $\begin{array}{l}19.95 \\
20.18 \\
19.5\end{array}$ \\
\hline 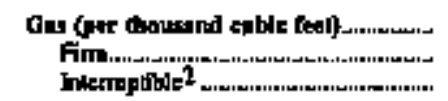 & $\begin{array}{l}238 \\
231 \\
240\end{array}$ & $\begin{array}{l}+61 \\
259 \\
266\end{array}$ & $\begin{array}{l}225 \\
233 \\
2.25\end{array}$ & $\begin{array}{l}2.02 \\
2.10 \\
1.96\end{array}$ & $\begin{array}{l}2.69 \\
2.77 \\
2.61\end{array}$ \\
\hline
\end{tabular}

I Doss not Inchda patroleven coke.

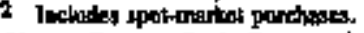

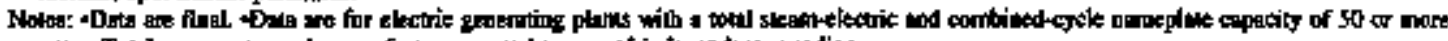

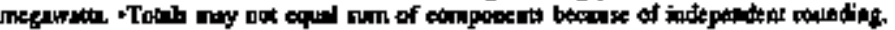

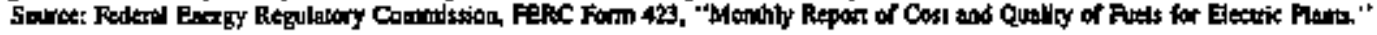


Table 15. Consumption of Fossil Fuels at U.S. Electric Utilities by Census Dirision and State, 1995 and 1996

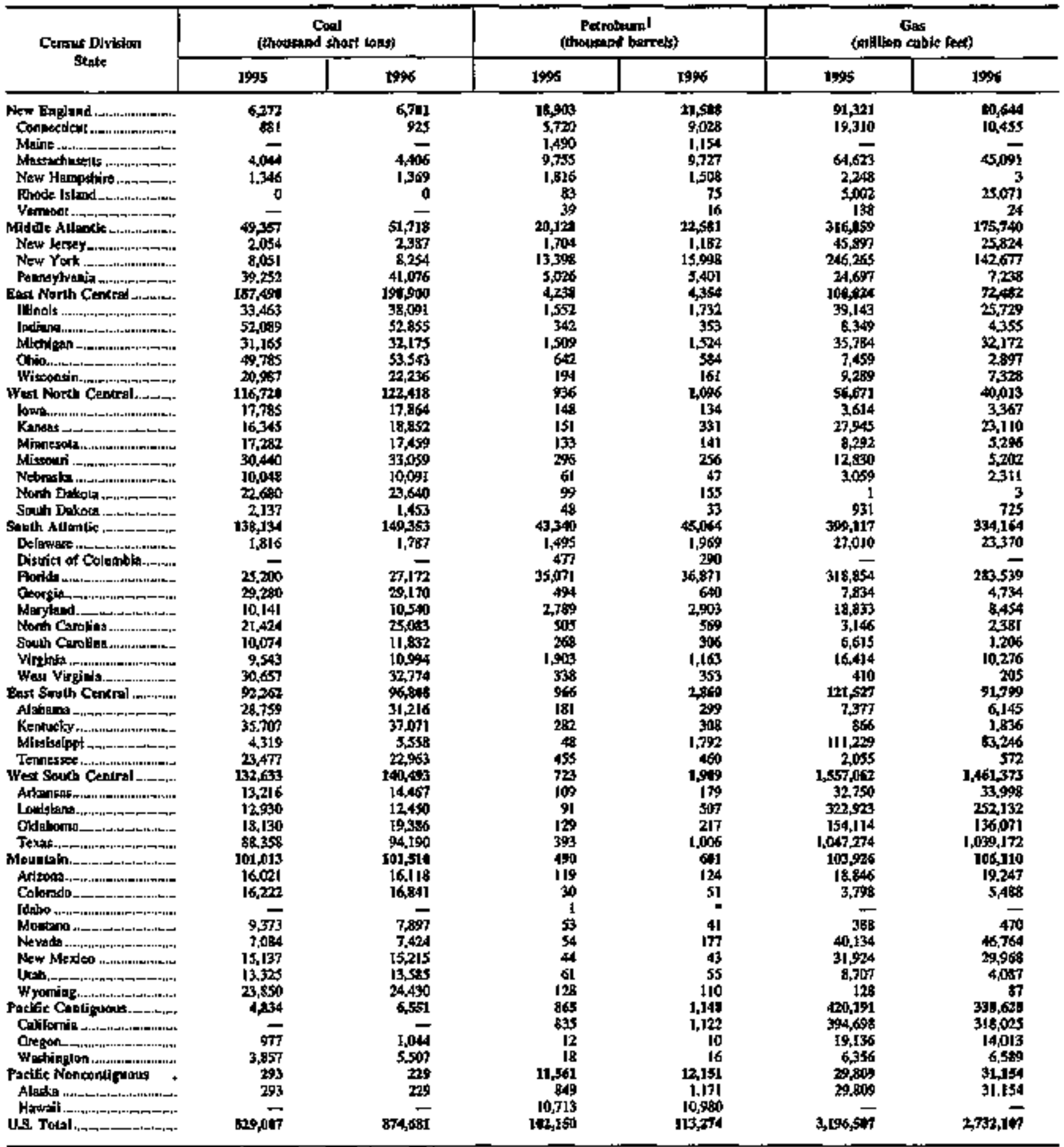

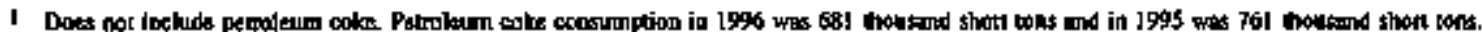

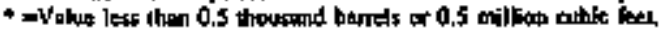

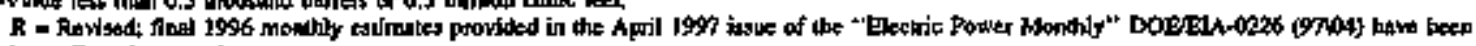

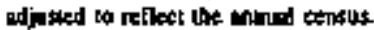

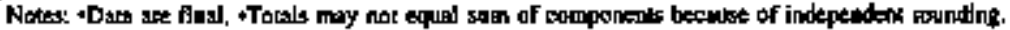

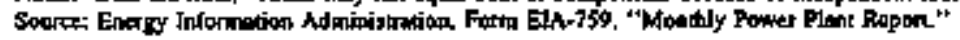


Table 16. Petrateum Consumption at U.S. Electric Utilities by Selected Prime Mover, Census Division, and State, 1995 and 1996

(Thousand Barrels)

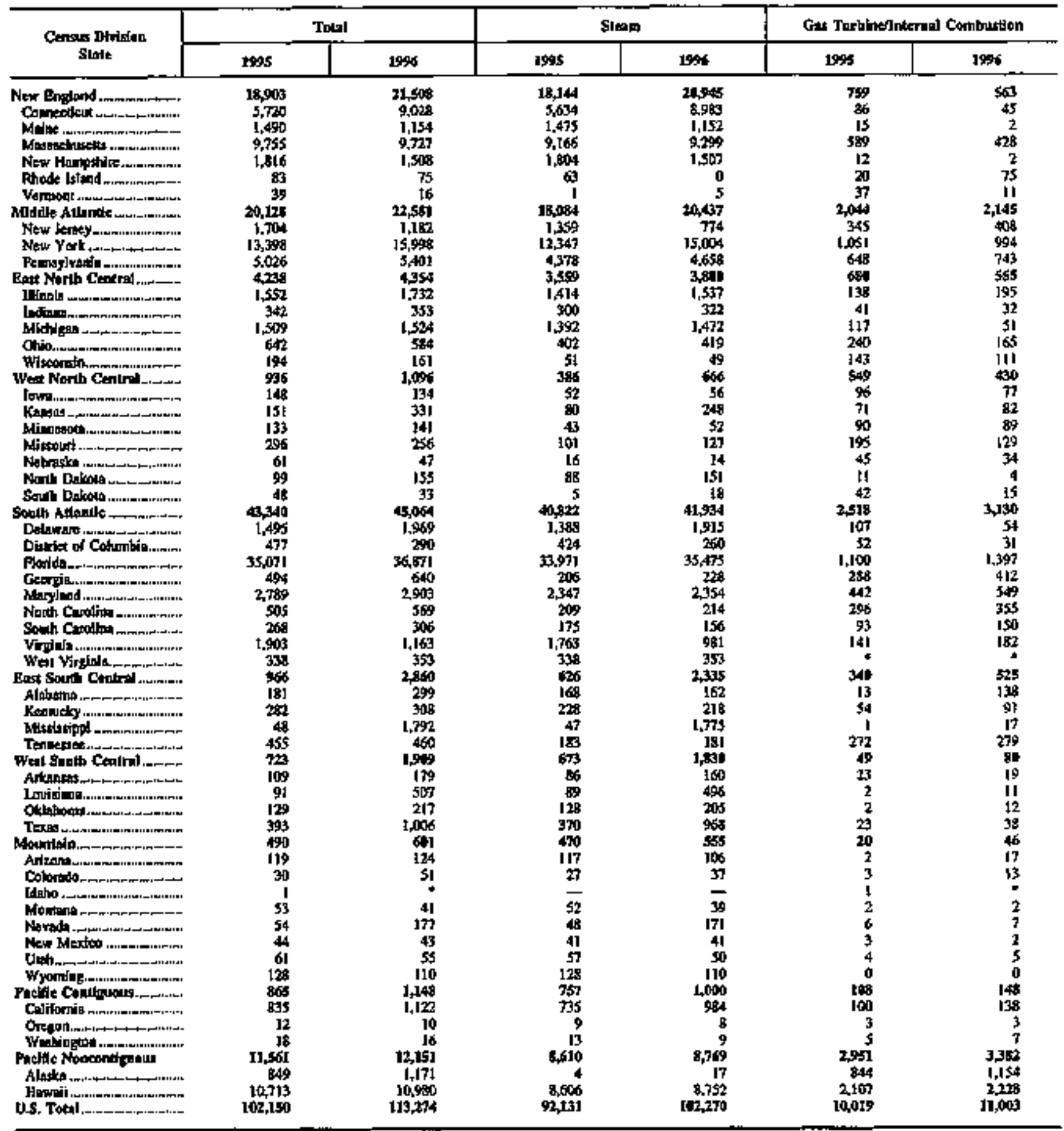

- aYalos leks inar 0.5.

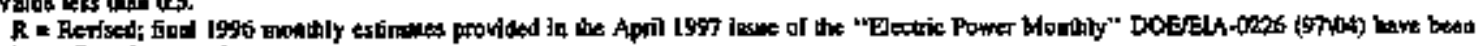
ofloded bo reflect te angand cerrall.

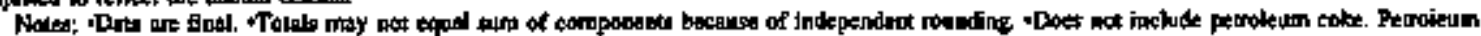

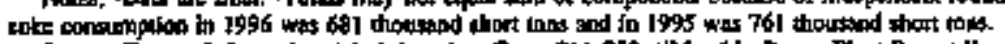

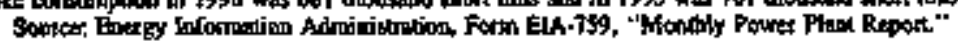


Table 17. Gas Consumption at U.S. Electric Uttilites by Selected Prime Mover, Census Division, and Slate, 1995 and 1996

(Million Cubic Feet)

\begin{tabular}{|c|c|c|c|c|c|c|}
\hline \multirow{2}{*}{$\begin{array}{c}\text { Cempis Dirluater } \\
\text { State }\end{array}$} & \multicolumn{2}{|c|}{ Total } & \multicolumn{2}{|c|}{ Stresin } & \multicolumn{2}{|c|}{ Gex Turblneifniemal Combestion } \\
\hline & $10 \times 5$ & 1996 & 1995 & 1596 & $\$ 95$ & 1996 \\
\hline 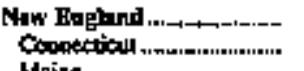 & $\begin{array}{l}1,321 \\
19,310\end{array}$ & $\begin{array}{l}84,64 \$ \\
10,455\end{array}$ & $\begin{array}{l}85,731 \\
18,310\end{array}$ & $\begin{array}{l}30,476 \\
8,526\end{array}$ & 5,390 & $\begin{array}{r}30,169 \\
1,969\end{array}$ \\
\hline 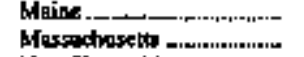 & $6462 \overline{3}$ & 45.091 & $5 \sin$ & $41 . \overline{25}$ & $5, \overline{382}$ & $3, \overline{165}$ \\
\hline New Hempdidnt - - & 2,249 & & 2,240 & & & \\
\hline 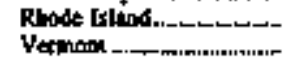 & 5,002 & 25,071 & 5,002 & $\mathbf{0}$ & - & 25,071 \\
\hline & 138 & & 138 & 34 & - & - \\
\hline $\begin{array}{l}\text { Mlddk Adnnds._-_-_-_-_- } \\
\text { New Jersey }\end{array}$ & $316,05 \%$ & 175,740 & 284,687 & 154,660 & $32,7 m$ & 21,079 \\
\hline $\begin{array}{l}\text { New Jersey. } \\
\text { New Yotk }\end{array}$ & $\begin{array}{r}45,697 \\
246,265\end{array}$ & $\begin{aligned} 25,804 \\
142,677\end{aligned}$ & $\begin{array}{r}28,119 \\
22,809\end{array}$ & $\begin{array}{l}15,593 \\
132,736\end{array}$ & $\begin{array}{l}17,778 \\
13,456\end{array}$ & $\begin{array}{r}10,293 \\
9,902\end{array}$ \\
\hline 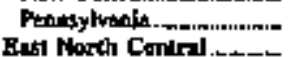 & 24,699 & 7.298 & 29,159 & 6,354 & 1.598 & 845 \\
\hline 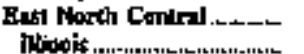 & $10+i 24$ & 72,482 & 82,270 & 0,531 & 17,754 & sist \\
\hline 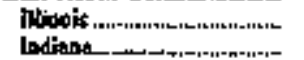 & 39,143 & 25,729 & 37006 & $34,35 t$ & 1,736 & 1,378 \\
\hline & 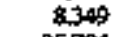 & 4,355 & 6,097 & 3,150 & 2,252 & 1,175 \\
\hline 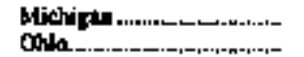 & 35,784 & 32,172 & 33,766 & 31,123 & 2,015 & 1.049 \\
\hline & $\begin{array}{l}7,469 \\
9,289\end{array}$ & 2.897 & 2,599 & 1,092 & 4,860 & 1,606 \\
\hline West North Ceaptratran- & 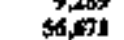 & $\begin{array}{r}7,728 \\
40,013\end{array}$ & $\begin{array}{r}2,803 \\
44027\end{array}$ & $\begin{aligned} 2,765 \\
\times 9,98\end{aligned}$ & 6,486 & 4,545 \\
\hline 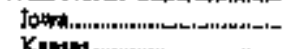 & 3,654 & 3.367 & 2,389 & $\begin{array}{r}28,928 \\
2,808\end{array}$ & $\begin{array}{l}13,645 \\
\text { t.225 }\end{array}$ & $\begin{aligned} 11,010 \\
559\end{aligned}$ \\
\hline 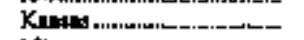 & 27,945 & $\mathbf{2 3 , 1 1 0}$ & 22,453 & 18,560 & 5,481 & 4,550 \\
\hline 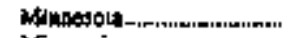 & 3,292 & 5,296 & 7,574 & 3,975 & 78 & I,321 \\
\hline 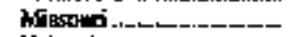 & 12,830 & 5,202 & 9,500 & 2318 & 3,290 & 2,834 \\
\hline 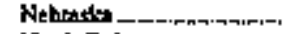 & 3.559 & 2311 & 1,915 & 1,240 & 1,144 & I,0\%0 \\
\hline North Dakgde-_ーつדר & j & 3 & 1 & 1 & , & 2 \\
\hline 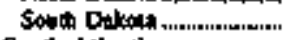 & & 725 & LA5 & 26 & 786 & 69 \\
\hline South Alandic..._-_-_.. & 399,117 & 334,164 & $275,41 \%$ & 191,684 & 123,07 & 142, \\
\hline Dellowart are & 27,010 & $23,3 \pi 0$ & 10,962 & 5,864 & 16.649 & 17,506 \\
\hline District of Columblatar & & $=$ & & - & - & - \\
\hline Fotid, & 318,254 & 283,539 & 243.950 & 176,122 & 74,904 & 107,417 \\
\hline 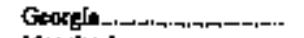 & 7,839 & 4,734 & 3,152 & 2,538 & 4,682 & 2,196 \\
\hline 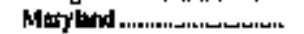 & 18,833 & B, 454 & 11,470 & 5,260 & 7,360 & 3,194 \\
\hline Narth Crooting & 3.146 & 2381 & 0 & 0 & 3.146 & 2381 \\
\hline South Croblin & 6,615 & 1,206 & $4, m 2$ & 399 & 1,644 & 807 \\
\hline 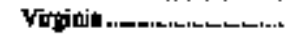 & 16,414 & 10.276 & 1,104 & 1.296 & $15,3,10$ & 8,980 \\
\hline 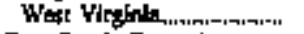 & 410 & 205 & 410 & 200 & - & - \\
\hline Rated Soukh Candral & 121,520 & 91,79 & 15,975 & 99,111 & 35,55 & 32,688 \\
\hline 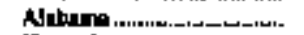 & 7,377 & 6,145 & 2,817 & 2,18 & 4560 & 3997 \\
\hline 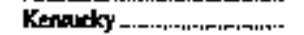 & 866 & 1,836 & 400 & 6]I & 466 & 1,224 \\
\hline Misdisuppl ...L_-_-_-_.. & 111,229 & 83,246 & B2,759 & $56,3] 1$ & $28, m$ & 26.935 \\
\hline Teqmosyes & 20055 & sn & & & 2,055 & $5 / 2$ \\
\hline West Sonth Crminl.......... & $1,557,062$ & $1,461,773$ & $1,039,446$ & $1,36,4,57$ & 97,615 & 100,866 \\
\hline 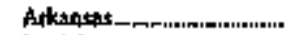 & 32.750 & 33,558 & 32750 & 33,998 & & \\
\hline 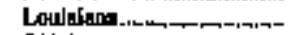 & 32,923 & 25,138 & 313,427 & 244,752 & 9,496 & 7351 \\
\hline Oklahona & $154,1] 4$ & $136 \mathrm{ml}$ & 121.879 & 104,026 & 32,735 & 32045 \\
\hline 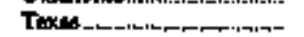 & $1,00723 d$ & $1,089,172$ & 991,390 & $9 \pi, x \in \mathbb{2}$ & $5,9 B \mathbf{S}$ & 61,470 \\
\hline 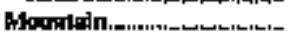 & 103,926 & 106,110 & 79,996 & 22,790 & $27, \$ 30$ & $33 ;-351$ \\
\hline 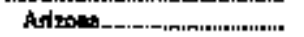 & 18.846 & 19.297 & 10.246 & 11,170 & 8600 & 8,076 \\
\hline 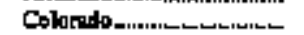 & 3,798 & $5,48 B$ & 3,682 & 4,181 & 115 & 1307 \\
\hline 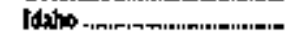 & - & - & - & - & ع & - \\
\hline Mantans _..-_-_-_-_-_-_ & 388 & $4 \mathrm{M} 0$ & $\mid 27$ & 165 & 262 & 305 \\
\hline 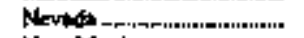 & 40.134 & 46,764 & 24,517 & 27,423 & 15,617 & 19,342 \\
\hline New Wexdeo & 31,924 & 29,968 & 30,136 & 27,24 & 1,768 & 2,244 \\
\hline Uhth._. & 8,707 & 4,008 & 7,140 & 2008 & 1,568 & 2078 \\
\hline Wyonlag:-u_-_-_-_- & 128 & & 128 & 8 & - & \\
\hline Pusfitic Chaliquous............ & 450,191 & 938,6283 & $37,7,0$ & 300,500 & 40,450 & 37,120 \\
\hline 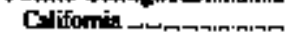 & 394,698 & 318,005 & 379,733 & 300,641 & 14,966 & 17,364 \\
\hline 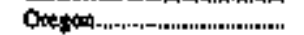 & 19.136 & 14,013 & 0 & 852 & 19.136 & {$[3,16]$} \\
\hline Wadingtan u______ & 6,356 & 6,589 & 9 & 7 & 6,347 & $6,3 \pm 2$ \\
\hline Paefife Noneond gaver. & $29, \mathrm{kng}$ & $3], 154$ & - & * & 290 & 31,154 \\
\hline Alatka & 20,809 & 31.154 & o & 0 & 29,600 & 31,154 \\
\hline 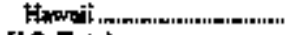 & & & - & - & $=$ & \\
\hline 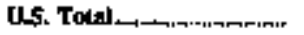 & $\$, 196,503$ & $2,73,107$ & $3, m / 893$ & $2,282,156$ & 423,514 & 49,95 \\
\hline
\end{tabular}

- Evalue leas that 0.5 .

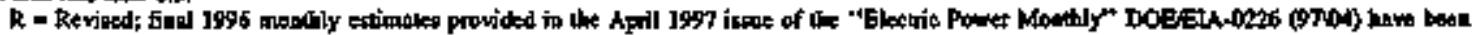

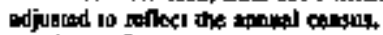

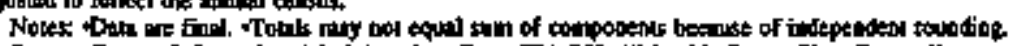

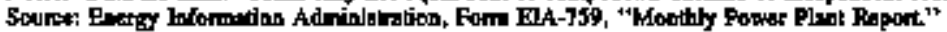


Table 18. Coal and Petroleum Stocks at U.S. Electric Utiltites by Census Division and State, as of December 31, 1995 and 1996

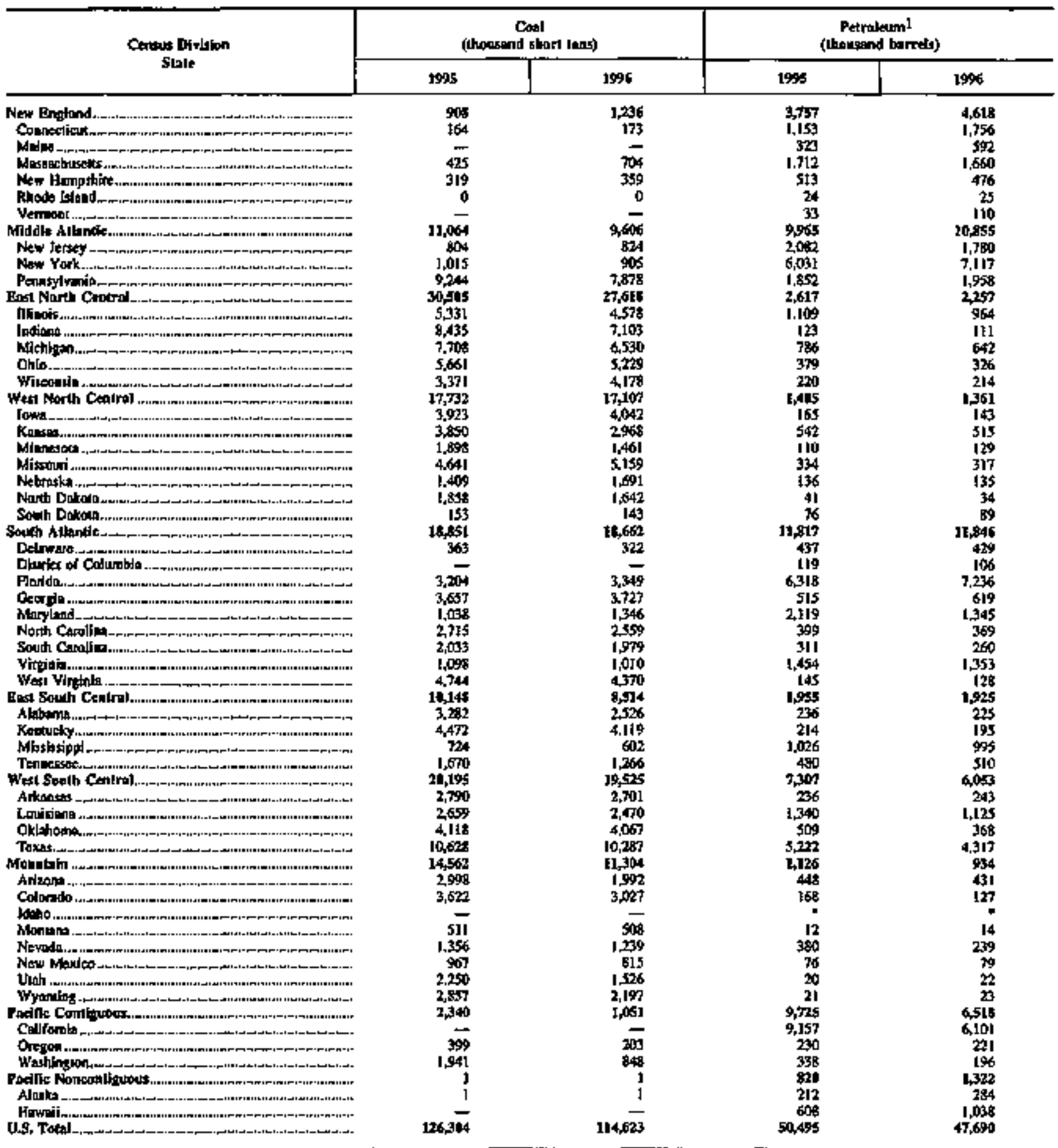

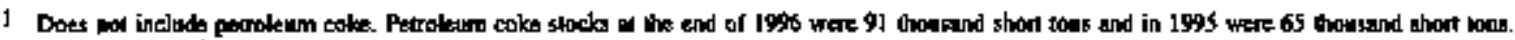
- Walux kes then 0.5.

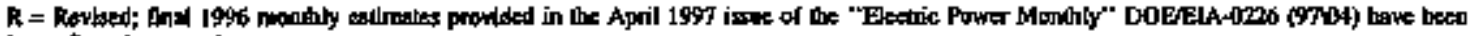

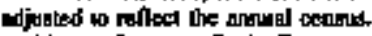

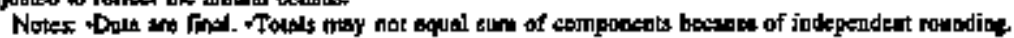

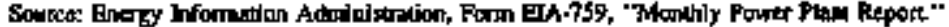


Table 19. Fossil Fuel Receipts at U.S. Electric Utilities by Census Dirision and State, 1995 and 1996

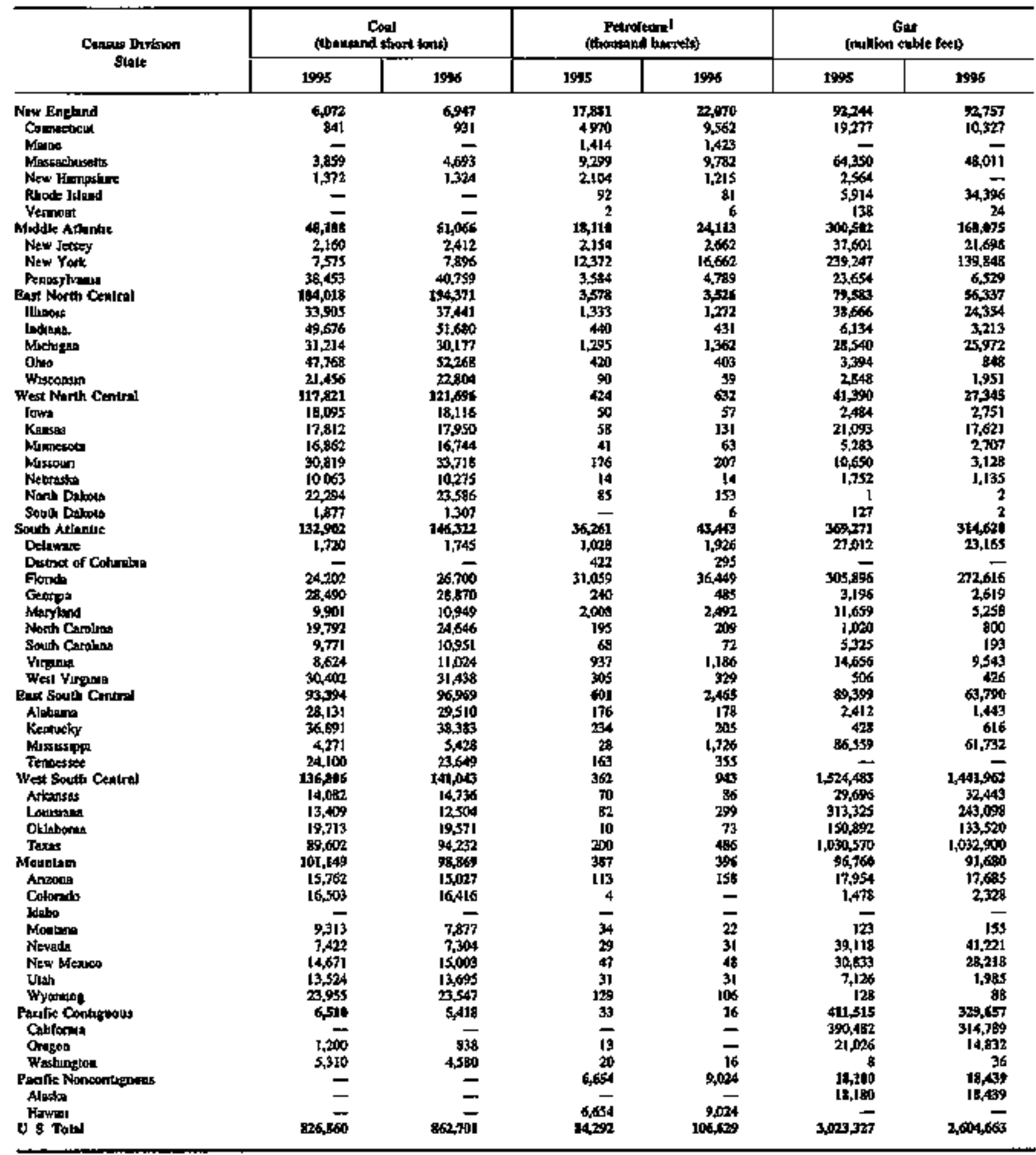

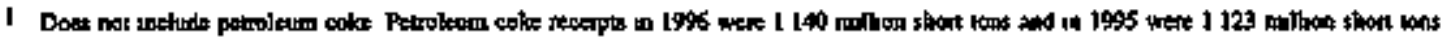

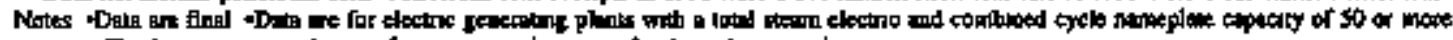

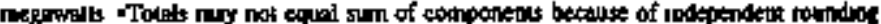

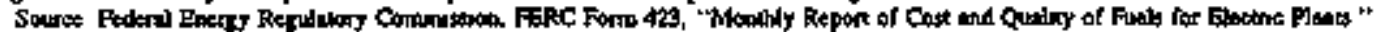


Tahle 20. Average Delivered Cost of Fossil Fuel Receipts at U.S. Electric Utilities by Census Division and State, 1995 and 1996

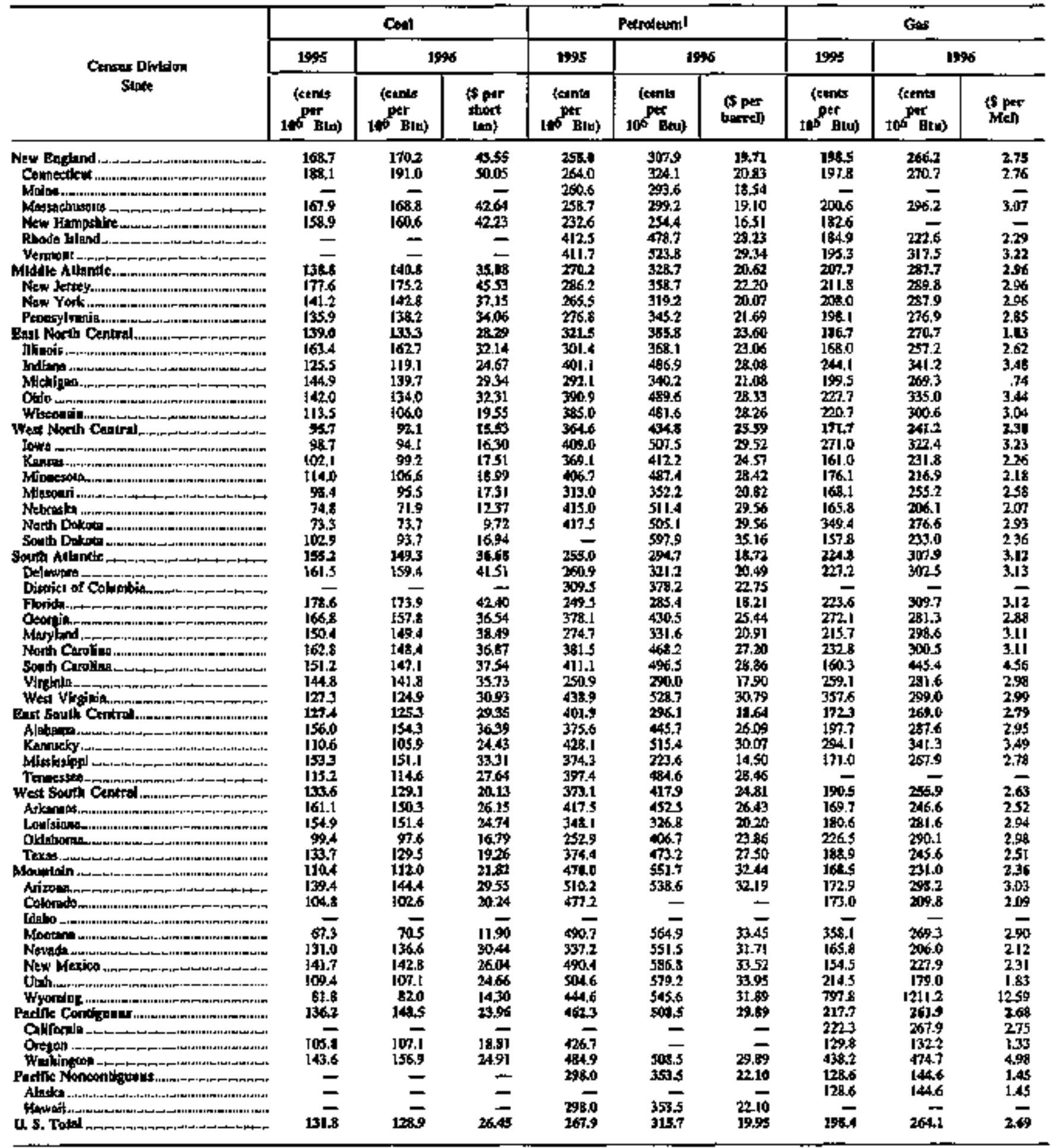

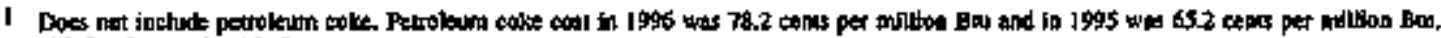
Mef te thausand cubie fees.

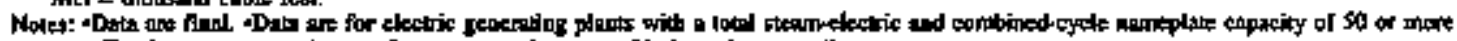

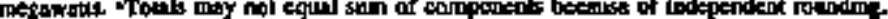

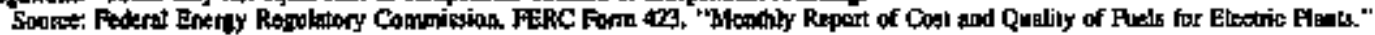





\section{U.S. Electric Utility Retail Sales, Revenue, and Average Revenue per Kilowatthour}

This chapter provides estimates on the sale of electricity to ultimate consumers by U.S. electric utilities, its associated revenue, and the average revenue per kilowatthour sold ${ }^{19}$ at the national, Census, and State levels for 1996 and final data for 1992 through 1995.

Because electricity cannot be stored, it must be generated, transmitted to the consumer, and consumed instantaneously. Electric utility companies were formed to provide these services. U.S. electric utilities are high-investment butifinesses and historically have been treated as monopolies because duplicate facilities, particularly transmission and distribution lines, would be inefficient. Thus, tranchises are granted to electric utilities for given geographical areas by regulatory officials. To obtain a franchise, electric utilities must provide service to all consumers in their territories at a reasonable cost. The service territory of an electric utility is usually composed of many combinations of consumers. Electric ufilities classify their consumers within end-use sector based on factors such as demand, rate schedule, and Standard Industrial Classification (SIC) code.

Prjvate households and apartment buildings, where energy is consumed primarily for space heating, water heating, air conditioning, lighting, refrigerration, cooking, and clothes drying are dassified as residential consumers. Nonumanufacturing busines establishments (including hotels, motels, restaurants, wholesale businesses, retail stores, health, social, and educstional institutions) are generally classified as commercial. However, demand or annual usage may be the determining factor used by the electric utility to classify a consumer as commercial. Manufacturing, construction, mining, agriculture, fisting, and forestry establishments (SIC codes 1-39) are included as industrial consumers. Again, electric utilites may instead classify industrial service based on demand or annual usage. Public street and highway lighting, railroads and railways, muricipalities, divisions or agencies of State and Federal govermunents under special contracts or agreements, and other utility departments as defined by the pertinent regulatory agency and/or electric utility within this report are classffied as other sales.
The average tevenue per kilowatthour of electricity sold by electric utilities is calculated by dividing total annual revenue by total annual retail sales for each sector and State. The resulting measurement is the cost (per kitowatthour of electricity sold) for providing service to a sector, given the rate schedule of the electric utility for that particular sector. The average revenue per kilowatthour is calculated for all consumers and for each sector (residential, commercial, industrial, and other sales). Utilities typically employ a number of rate schedules within a single sector. These alternative rate schedules reflect the varying consumption levels and patterns of these customers and their associated impact on the cost to the electric utility for providing electrical service. The average revente per kilowatthour by sector reported in this publication represents a weighted average of revenue and sales within and across sectors for all consumers.

To derive the average revenue per kilowatthour, the operating revenuxe reported by the electric utility is used. Utility operating revenues cover-among other costs of service-State and federal income taxes and taxes other than income taxes paid by the utility. The federal component of these taxes are, for the most part, payroll taxes. State and local authorities will tax the value of plant (property taxes), the amount of revenues (gross receipts taxes), purchases of materials and services (sales and use taxes), and a potentially long list of other taxes that vary extensively by taxing authority. Taxes deducted from an employee's pay, such as federal income taxes and the employee's share of social security taxes, are not a part of the utility's "tax costs," but are paid to the taxing authorities in the rame of the employees. These taxes are included in the ulility's cost of service (for example, revenue requirements) and are included in the amounts recovered front the customer in rates and reported in operating revenues.

Electric utilities, like many other business enterprises, are required by various taxing authorities to collect and remit taxes assessed on its customers. In this regard, the utility serves as an agent for the taxing authoxity. Taxes assessed on the constmer, such as a gross receipts tax or sales tax,

19 Average cevenue per kilowatheur is the ralio of revenue to retail sales.

7. Includes energy charges, demand charges, consumer service charges, elvirgamendal surcharges, fuel odjustments, and other miscetlaneous charges. 
are referred to as pass through taxes. These taxes do not represent a cost of the utility and are not recorded in the operating revenues of the utility. However, taxing authorities differ regarding whether a specific tax is assessed on the utility or on the consumer. That decision, in tam, determines whether or not the tax is included in the electric utility's operating revenue.

Average revenue per kilowatthour from residential consumers is generally higher than for any other sector, in part due to the higher costs associated with serving many consumers who use relatively small amounts of electricity. These higher costs indude direct-load costs (such as those for distribution lines) in addition to consumer or administrative costs. The industrial sector, which genterally has the highest use of electricity, has the lowest average revernue per kilowathour.

\section{Data Sources}

Preliminary values for 1996 are derived from data collected on the Form EIA-826, "Monthly Electric Utilfty
Sales and Revenue Report with State Distributions." Respondents to the Form ELA-826 are based on a statistically chosen sample and include 252 U.S. electric utilities from a universe of approximately 3,250 utilities. The sample was designed to obtain estimates of electricity sales, average revenue, and revenue per kilowatthour for all U.S. electric utilities by end-use sector. Estimates of coefficients of variation, which indicate possible error caused by sampling, are also published at each level.

Historical sersus-based statistics on retail sales of electricity, associated revenue, and average revenue per kilowatthour are based on information collected on the Form EIA-861, "Annual Blectric Utility Report" Firal census-based statistics for retail sales of electricity, associated reventte, and average revenue per kilowatthour based on information collected on the Form EIA-861 will be published in the Electric Sales and Retrentie, DOE/EIA-0540. 
Table 21. Retall Sales by U.S. Electric Utilltes to Ultimate Consumers and Assoctated Revenue by Sector, 1992 Through 1996

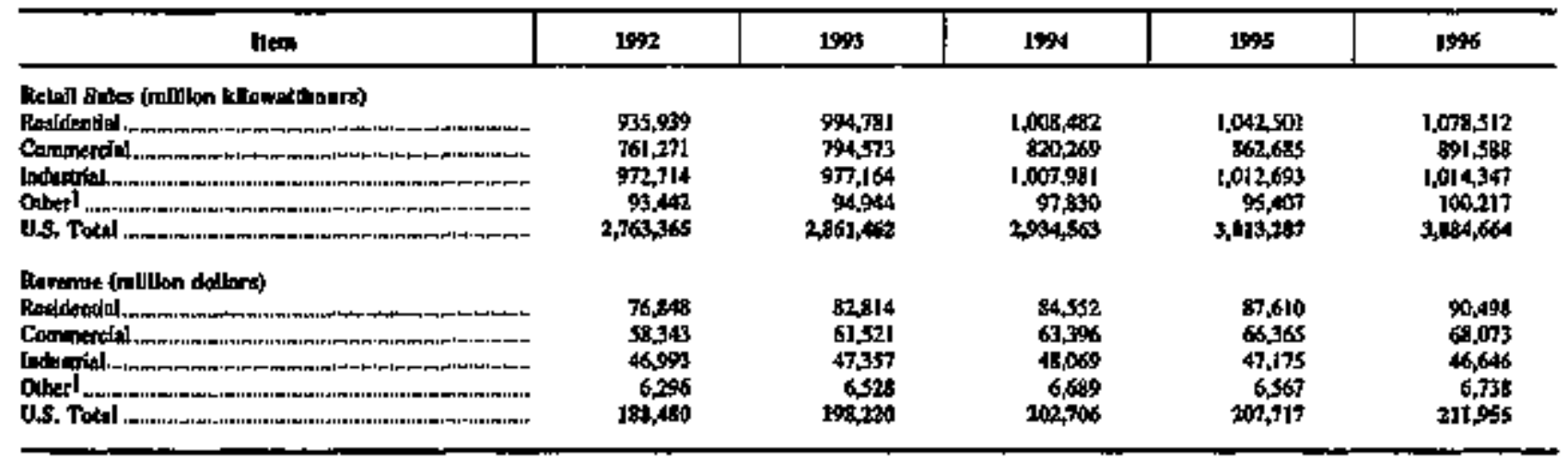

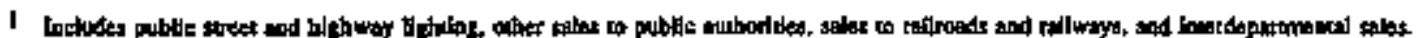

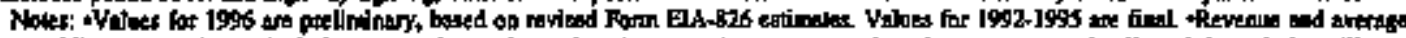

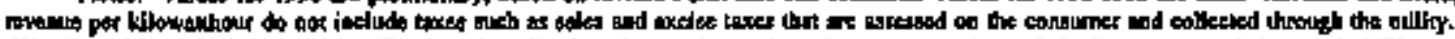

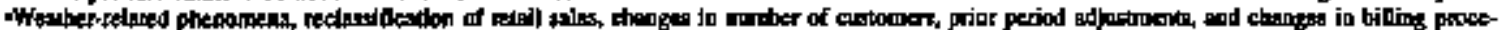

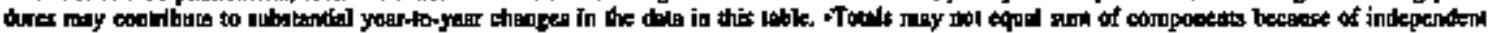
rorndilng

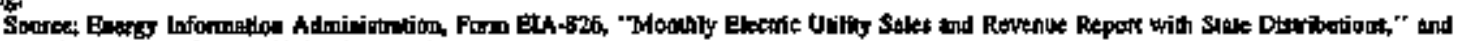

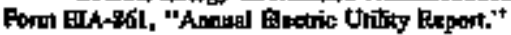

Table 22. A perage Revenue per Kifowatthour for U.S. Electric Utilities by Sector, 1992 Throuth 1996

(Cents)

\begin{tabular}{|c|c|c|c|c|c|}
\hline Secter & 1992 & $19 \sin$ & 1994 & 1995 & $199 x$ \\
\hline 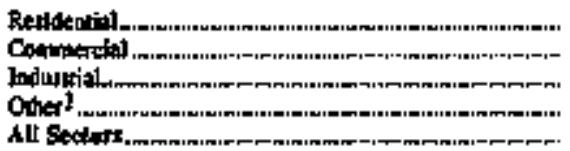 & $\begin{array}{l}5.21 \\
1.65 \\
1.83 \\
6.74 \\
6.62\end{array}$ & $\begin{array}{l}8.32 \\
7.74 \\
4.85 \\
6.88 \\
6.98\end{array}$ & $\begin{array}{l}\$ .38 \\
7.73 \\
4.77 \\
6.84 \\
6.91\end{array}$ & $\begin{array}{l}6.40 \\
7.68 \\
4.66 \\
6.89 \\
6.86\end{array}$ & $\begin{array}{l}8.39 \\
1.63 \\
4.60 \\
6.77 \\
6.87\end{array}$ \\
\hline
\end{tabular}

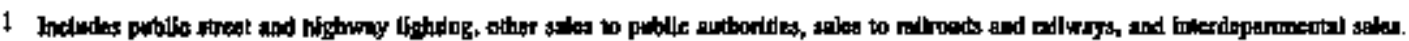

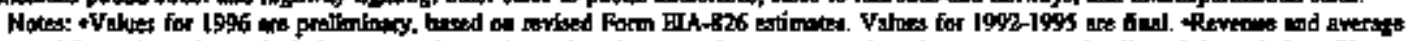

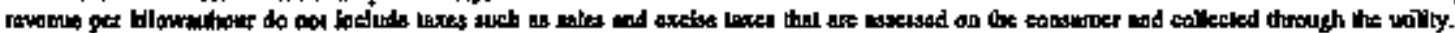

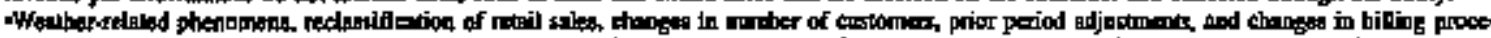

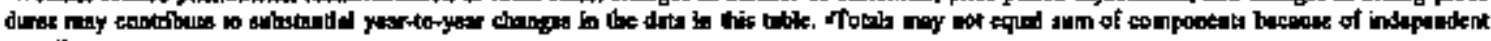
roting.

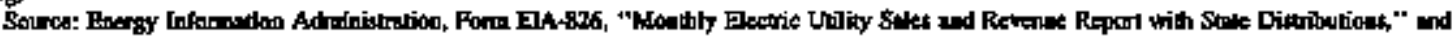

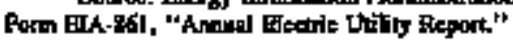


Table 23. Retail Sales of Electricity by U.S. Electrle Utlities to Ultimate Consumers by Sector, Census Division, and State, 1996 (Million Kilowatthours)

\begin{tabular}{|c|c|c|c|c|c|}
\hline $\begin{array}{l}\text { Cenars lividon } \\
\text { and Stats }\end{array}$ & AD Shators & Restdenlipd & Comentreid & Indnosirlel & Oubarl \\
\hline 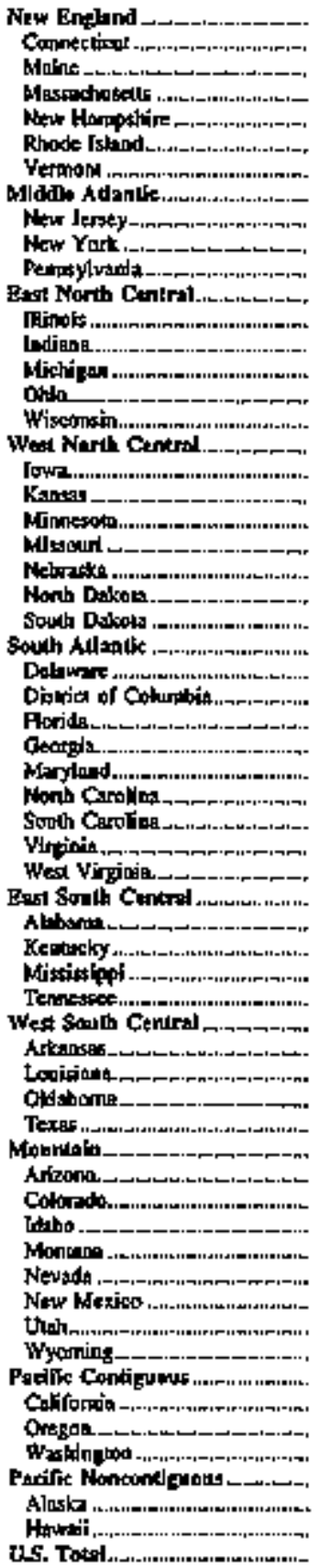 & 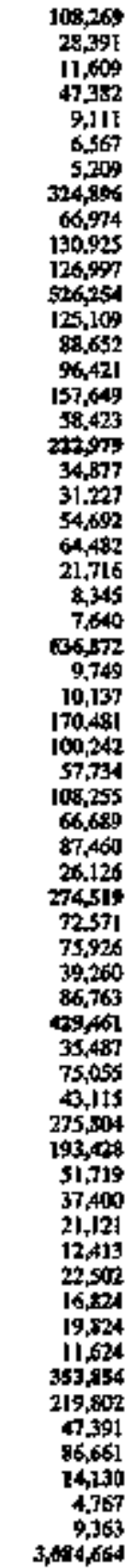 & 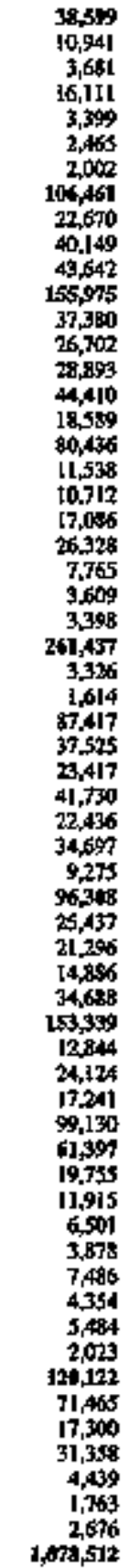 & 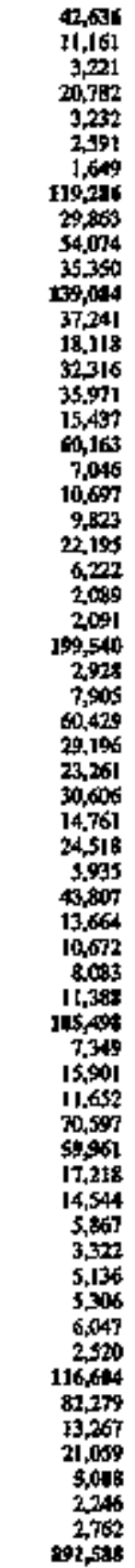 & 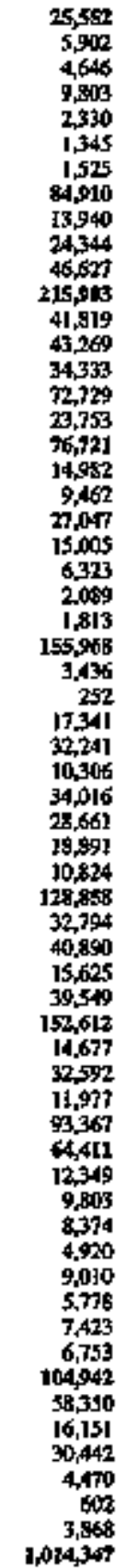 & 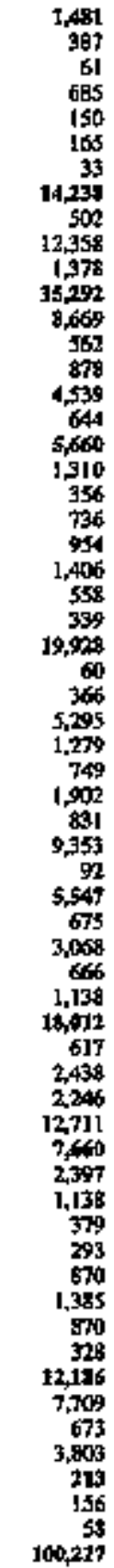 \\
\hline
\end{tabular}

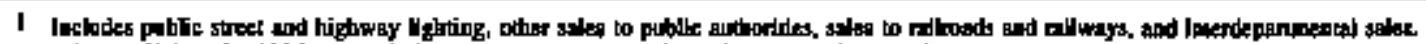

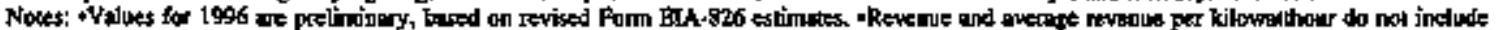

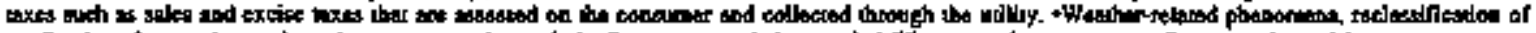

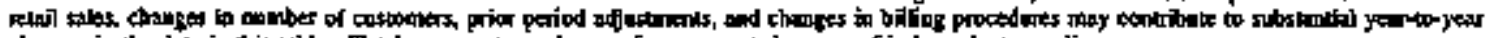

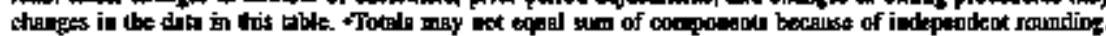

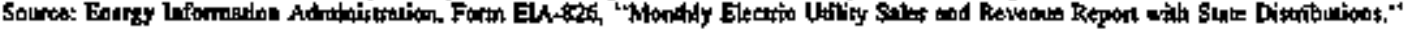


Table 24. Estimated Coefficients of Vartatton for U.S. Electric Utility Retail Sales of Electricity by Census Divislon and State, 1996

(Percent)

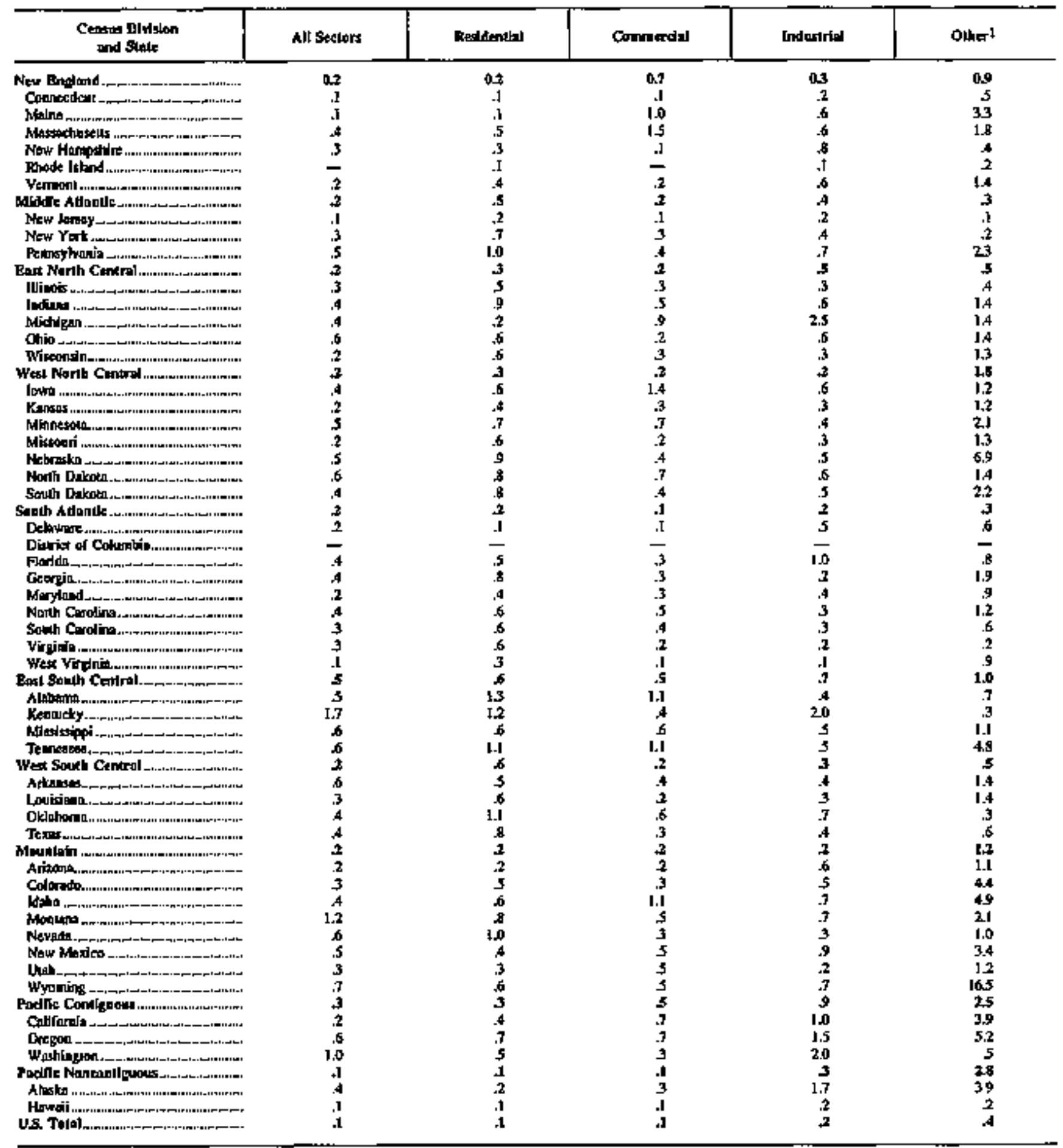

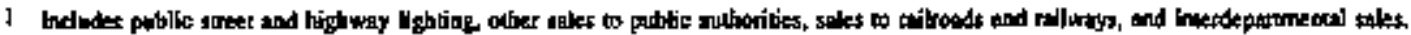

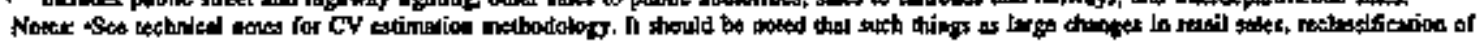

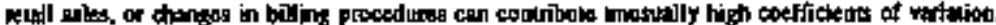

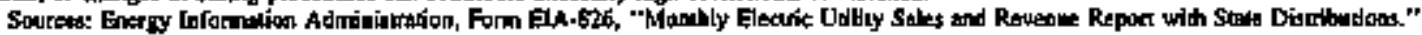


Table 25. Revenue from Retail Sales by U.S. Electric Utilities to Ultingte Consumers by Sector, Census Dirision, and State, 1996 (Millon Dollars)

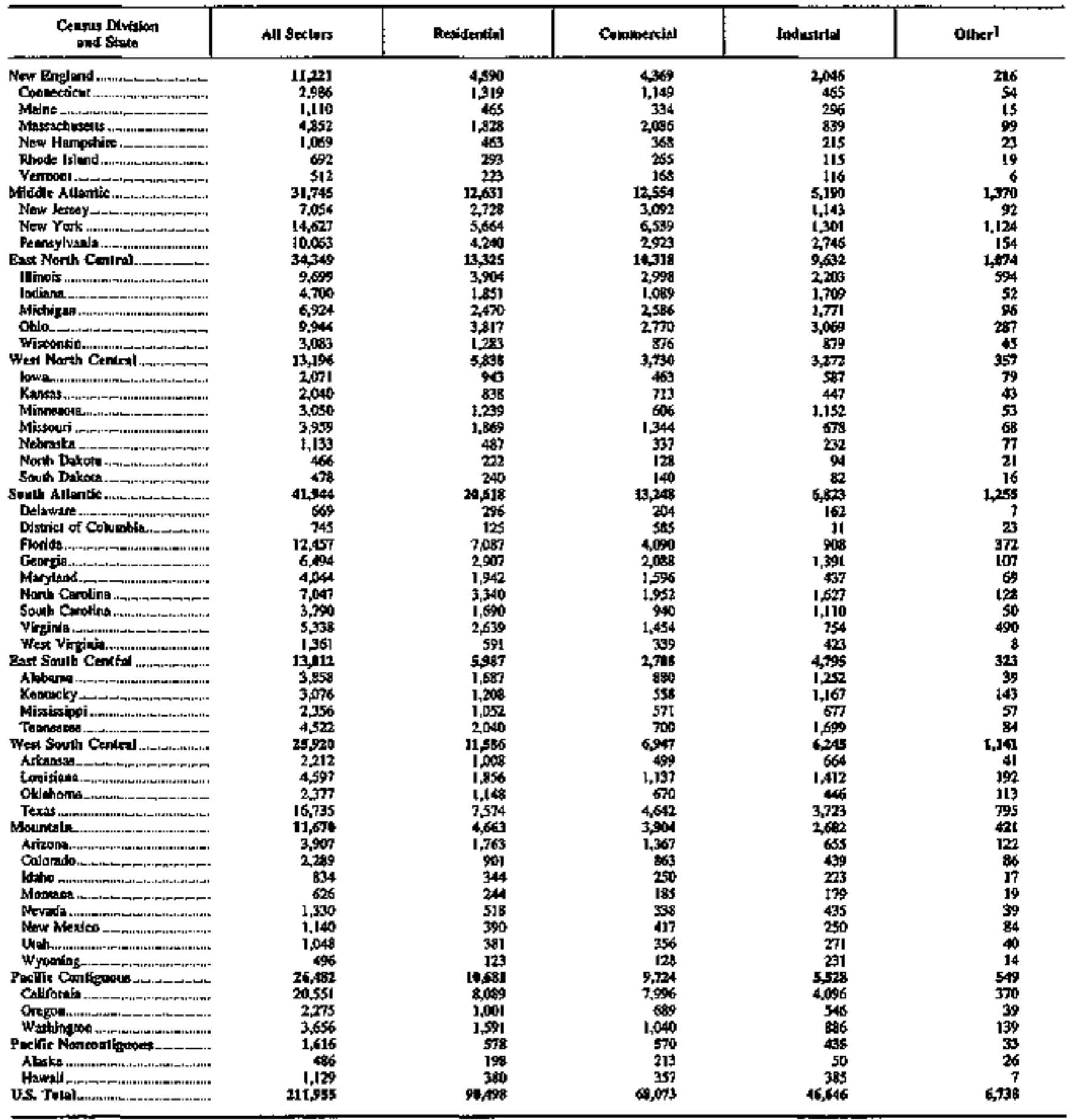

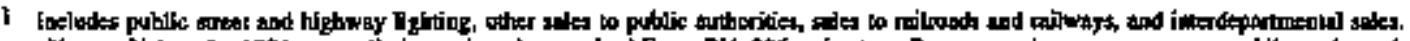

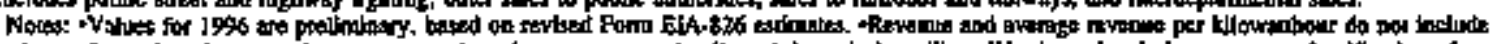

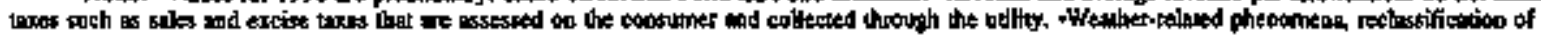

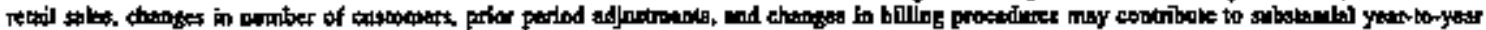

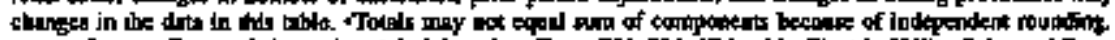

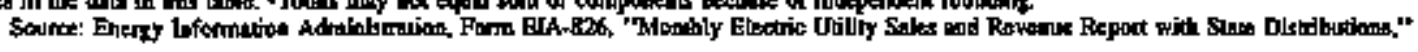


Table 26. Estimated Coemicients of Variation of Revenue from Retail Sales by U.S. Electric Utilities by Census Division and State, 1996

(Percent)

\begin{tabular}{|c|c|c|c|c|c|}
\hline $\begin{array}{l}\text { Cenagy bulwsion } \\
\text { and stout }\end{array}$ & All Sectors & Hedolantit| & Contuteralet & Indatal & Othar 1 \\
\hline 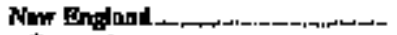 & 03 & 03 & $\omega$ & 05 & 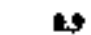 \\
\hline 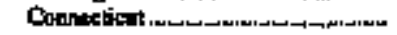 & .2 & 2 & .2 & .1 & .2 \\
\hline Minl & .1 &. $\mathrm{I}$ & .9 & $s$ & 1.9 \\
\hline Masuschusefs' & .7 & .7 & I. 8 & 1.1 & 1.8 \\
\hline 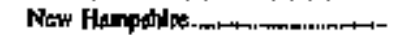 & 5 & .6 & 3 & 9 & 23 \\
\hline Bhode Ifind & .1 & .1 & .1 & 2 & .3 \\
\hline 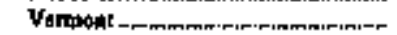 & .6 & 5 & .5 & 1.1 & 1,0 \\
\hline MLdde Aflandte. & 3 & 5 & 3 & 3 & g \\
\hline New kroy.......... &.$t$ & 1 & .1 & 3 & $=$ \\
\hline 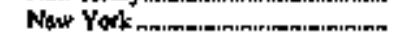 & 5 & 6 & 5 & 5 & .5 \\
\hline 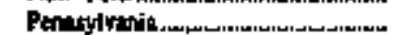 & .7 & 1.2 & .6 & .6 & 1.2 \\
\hline 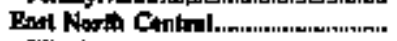 & 2 & 3 & 3 & ي & .2 \\
\hline 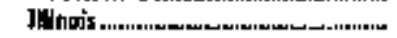 & .4 & .6 & 2 & $A$ & 3 \\
\hline 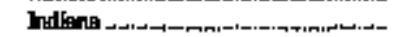 & 6 & 10 & .6 & .8 &. \\
\hline 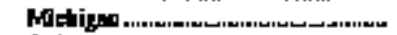 & 6 & 3 & .9 & 2.4 & .8 \\
\hline 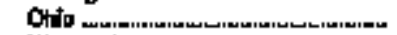 & 3 & 6 & .3 & .4 & .5 \\
\hline 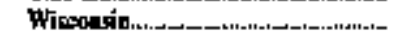 & .3 & 6 & .3 & .3 & Is \\
\hline West North Canlral_..... & 3 & 3 & 3 & 3 & 12 \\
\hline 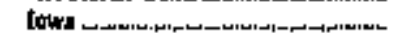 & 4 & 3 & s & .7 &. $\bar{B}$ \\
\hline Kanup_...n........ & 3 & 5 & 4 & .5 & 2.3 \\
\hline Minoesolo.............................. & .6 & .7 & .9 & 4 & 1.0 \\
\hline 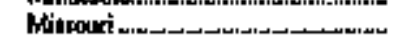 & 7 & 8 & .5 & 1.0 & 1.2 \\
\hline Netbrike....... & 8 & 9.1 & .7 & 1.4 & S.I \\
\hline 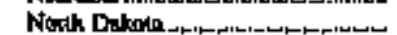 & 5 & 6 & 6 & .5 & 10 \\
\hline Sowth Dekat & .6 & .9 & .5 & .5 & 1.9 \\
\hline Souta Alhneis & 3 & 3 & 2 & 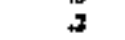 & 3 \\
\hline 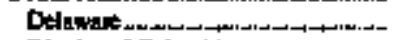 & .1 &.$I$ & .2 & .0 & $A$ \\
\hline 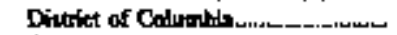 & - & - & - & - & - \\
\hline 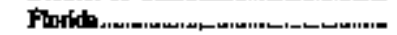 & 4 & 5 & .4 & I.0 & .7 \\
\hline 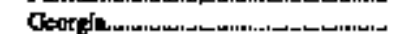 & .6 & $\sqrt{2}$ & .3 & .2 & 1.3 \\
\hline Marybnd & $s$ & .9 & 6 & 9 & .4 \\
\hline 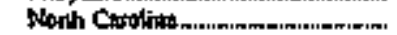 & .5 & .7 & 6 & $s$ & 1,3 \\
\hline 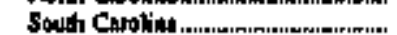 & .5 & 1.0 & 4 & $\vec{A}$ & .6 \\
\hline Yhtdin & 4 & .3 & .3 & .2 & .3 \\
\hline Weal Virenin. & 西 & 3 & .2 & .1 & 9 \\
\hline Bax South Cenlrad & 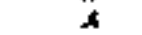 & .6 & $s$ & 4 & 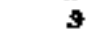 \\
\hline Allahams & .7 & 13 & I.I & 5 & 2.4 \\
\hline Kenluasky & 3.1 & I.6 & .6 & 1.0 & $A$ \\
\hline 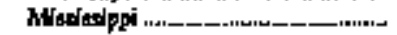 & .7 & $\$$ & .6 & .3 & $1 \mathrm{~A}$ \\
\hline Tenonosse. & .6 & 1.0 & I.I & 6 & 3.3 \\
\hline Wort Santh Ceninl & 3 & 5 & 3 & 4 & 5 \\
\hline 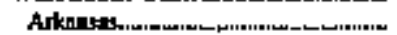 & 3 & 3 & .4 & .6 & 1.8 \\
\hline 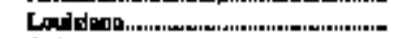 & .4 & .6 & .5 & .2 & .5 \\
\hline Oklnorth & 9 & 1,4 & 1.3 & .8 & .4 \\
\hline Texas........................ & 5 & 8 & 4 & .6 & .7 \\
\hline Mointeth .............................. & 2 & \pm & .7 & 3 & 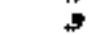 \\
\hline Arronn & 3 & 4 & .3 & .6 & 1.3 \\
\hline Colorodo.n. & 3 & 4 & 2 & 5 & 1,3 \\
\hline Gath & .6 & $s$ & 1,2 & 1.3 & $\mathbf{3 , 0}$ \\
\hline Alotulun & 1.0 & .6 & .7 & 5 & 2.4 \\
\hline Wevade & $s$ & \pm .0 & .3 & 1.0 & .7 \\
\hline Hew Nexien & 5 & 6 & .5 & 1.0 & $\mathbf{3 . 4}$ \\
\hline 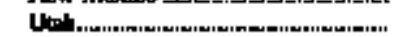 & 3 & 3 & 5 & 3 & Is \\
\hline Wronfot & $\pi$ & 8 & .5 & 8 & 7.3 \\
\hline Padic Condintods. & $s$ & .4 & $\mathbf{L L}$ & 13 & 15 \\
\hline Colkoutina & .6 & 5 & 13 & 1.7 & $\mathbf{2 . 1}$ \\
\hline Orogon & .7 & g & 5 & 1.8 & 2.1 \\
\hline Washinglon. & $g$ & 5 & .6 & 23 & 1.0 \\
\hline 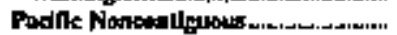 & 2 & .1 & 2 & 4 & 2.4 \\
\hline Alesk _ & .6 & 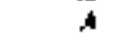 & 3 & 2,3 & 3.6 \\
\hline Hewain & .1 & .1 &.$t$ & .3 & 3 \\
\hline 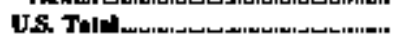 & I & 1 & 3 & 3 & 2 \\
\hline
\end{tabular}

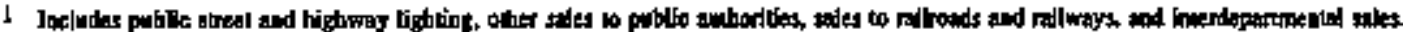

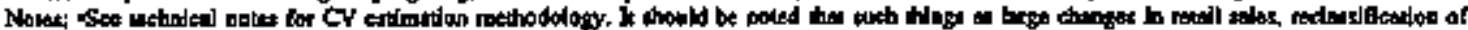

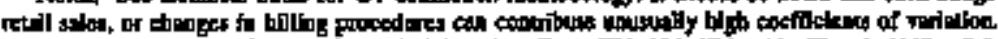

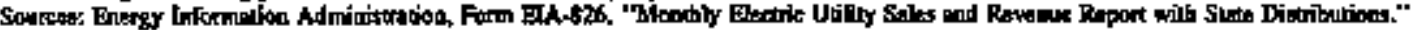


Table 27. Average Revenue per Kilowatthour for U.S. Electric Utlities by Sector, Census Division, and State, 1996 (Cents)

\begin{tabular}{|c|c|c|c|c|c|}
\hline $\begin{array}{c}\text { Censint Dividian } \\
\text { and Stota }\end{array}$ & All Sudont & Retetertal & Commerciat & lafustaid & OHinel \\
\hline 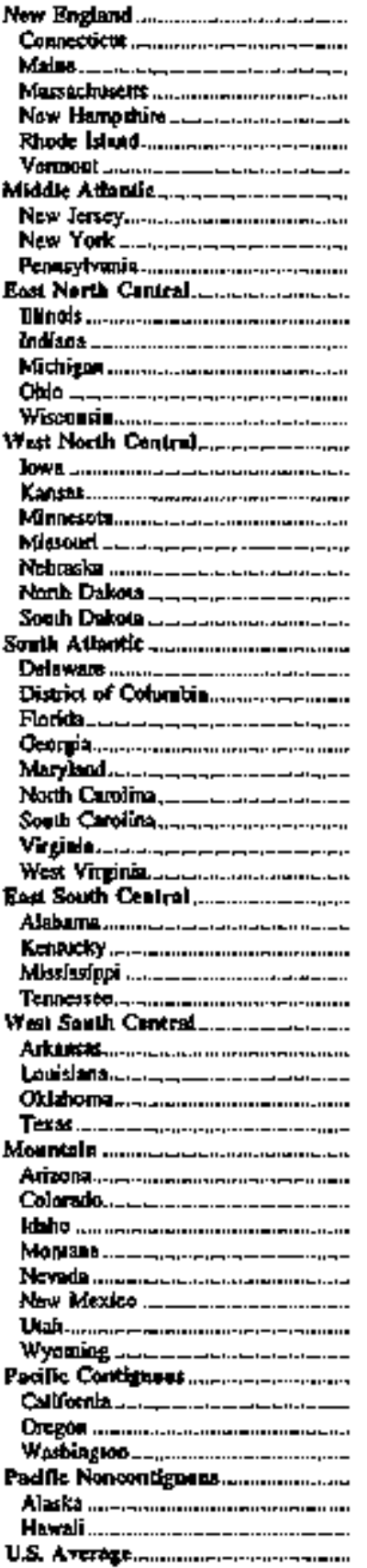 & 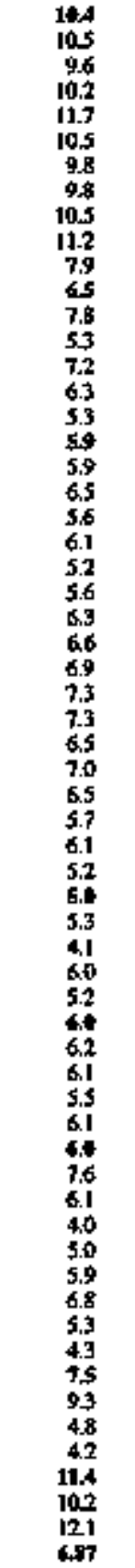 & 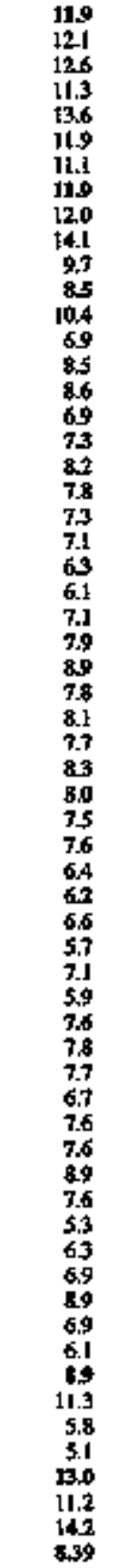 & 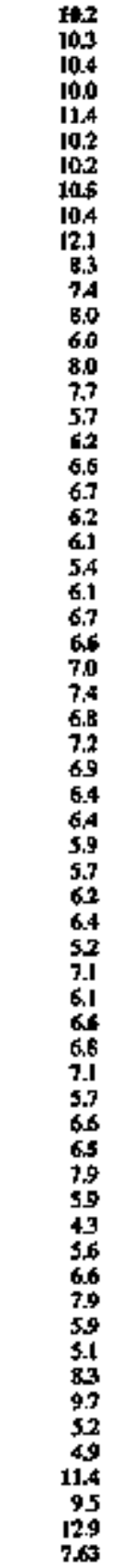 & 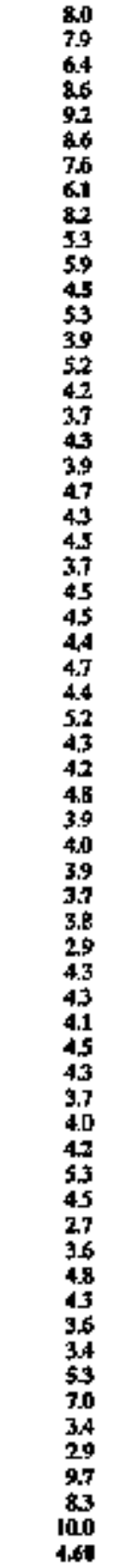 & 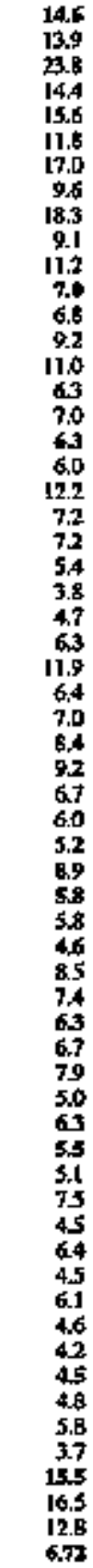 \\
\hline
\end{tabular}

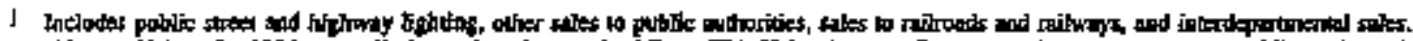

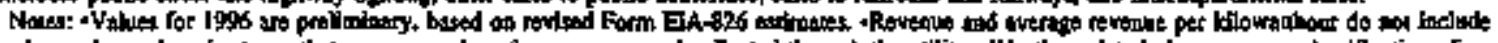

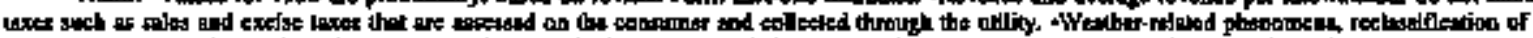

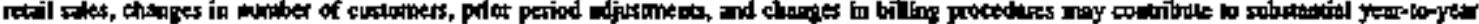

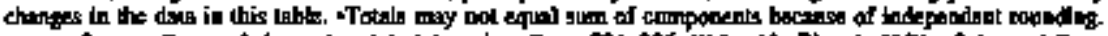

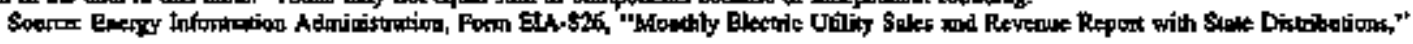


Table 28. Estimated Coefficients of Variation for Average Revenue per Killowatthour for U.S. Electric Utilities by Sector, Cenșus Division, and \$tate, 1996

(Percent)

\begin{tabular}{|c|c|c|c|c|c|}
\hline $\begin{array}{c}\text { Census Blutsion } \\
\text { und Sind }\end{array}$ & All Bechors & Reddendal & Connowral & Induintol & Other 1 \\
\hline 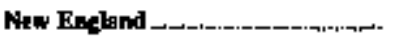 & 0.2 & 0.3 & 0.4 & 03 & 0.7 \\
\hline 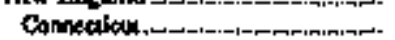 & .1 & .1 & .1 & 2 & $d$ \\
\hline 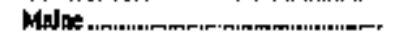 & .1 & - & 2 & 2 & 1.2 \\
\hline 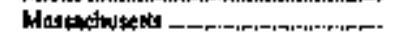 & $\$$ & $\boldsymbol{B}$ & 9 & .7 & I.4 \\
\hline Now Hampthopor & 3 & $\boldsymbol{A}$ & .4 & .4 & 23 \\
\hline 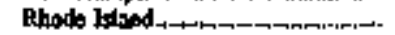 & .1 & .2 & .1 & .2 & 3 \\
\hline Vamode & 5 & .7 & 5 & .6 & 1.5 \\
\hline 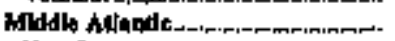 &. & .2 & 1 & 2 & 3 \\
\hline Mew Jeptoy & - & .1 & $=$ & .1 & .2 \\
\hline 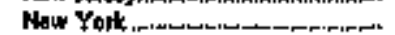 & .2 & 3 & 3 & .4 & A \\
\hline 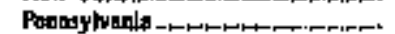 & .3 & $A$ & 3 & 1 & 1.2 \\
\hline Ras Narih Cealra1..... & 2 & .2 &. & 2 & $s$ \\
\hline 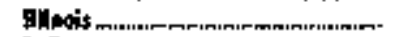 & 3 & 4 & 3 & 2 & 2 \\
\hline Todpas _...r. & .4 & .5 & 3 & .4 & 1.4 \\
\hline 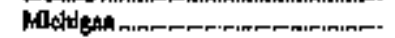 & $\$$ & .2 & .1 & 4 & .7 \\
\hline Otho , & .6 & .3 & 3 & 3 & 1.8 \\
\hline Wisconsin'_-_C-C- & .2 & .2 & .I & 3 & 1.5 \\
\hline 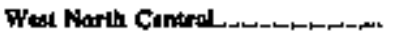 & $\mathbf{3}$ & 3 & 2 & 3 & L.0 \\
\hline Kow1 & 4 & 5 & .8 & $\boldsymbol{s}$ & .7 \\
\hline 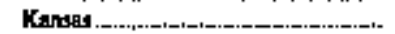 & .2 & .4 & .2 & 3 & 29 \\
\hline 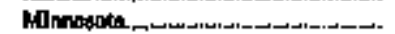 & .5 & .4 & 3 & 6 & 1.2 \\
\hline 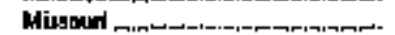 & .7 & .7 & .6 & .9 & .8 \\
\hline Nebretke & .6 & .7 & .5 & I3 & 27 \\
\hline Nonh Dukpoli.4. & .3 & $A$ & 3 & 4 & 9 \\
\hline 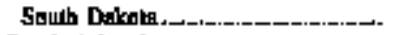 & 4 & $A$ & 5 & 4 & 1.3 \\
\hline 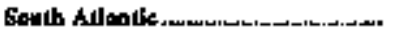 & 2 & .2 & 2 & .1 & $\mathbf{t}$ \\
\hline 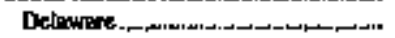 &. $\mathbf{I}$ & .1 &. $\mathbf{I}$ & 3 & .3 \\
\hline Destex of Cohurribla._. & - & - & - & - & - \\
\hline 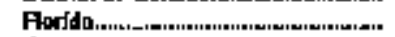 & .4 & $A$ & 5 & 5 & .3 \\
\hline detorgh & .4 & 8 & 3 & 2 & 3 \\
\hline Morgland.... & 3 & 4 & 4 & 5 & 8 \\
\hline Nond Corotins........................... & .3 & 4 & 3 & 4 & .5 \\
\hline Solvi Corollna & .4 & $\$$ & 5 & 3 & 3 \\
\hline 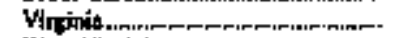 & 2 & .2 & .3 & 2 & .3 \\
\hline 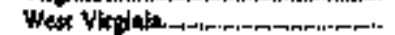 &. $\mathbf{I}$ & .1 & .1 & $=$ & 1.4 \\
\hline Enal Santh Ceniret & 4 & .I & .1 & .6 & 4 \\
\hline Alubarit & 3 & .2 & 3 & 5 & 2.4 \\
\hline 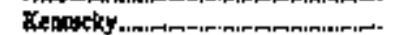 & 1.4 & .5 & 4 & i.7 & .3 \\
\hline 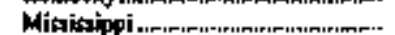 & 3 & A & 3 & 4 & 1.0 \\
\hline 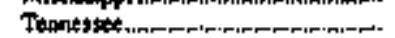 & 3 & .1 & 3 & 3 & 1.5 \\
\hline Wea South Cesolral., & 2 & $\mathbf{3}$ & 3 & 2 & .4 \\
\hline Adtentots & 6 & .5 & 5 & 5 & 10 \\
\hline 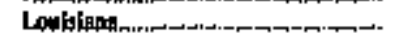 & 2 & 3 & 4 & 2 & 1.9 \\
\hline 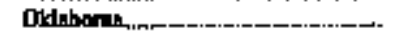 & 6 & .4 & .3 & 5.0 & .2 \\
\hline 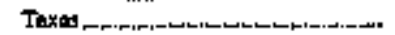 & .3 & $A$ & 4 & 4 &. \\
\hline Moumlaim &. $\mathbf{I}$ & .t. & 2 & 2 & $\$$ \\
\hline Arl2oub, & .4 & .3 & 3 & .7 & .9 \\
\hline 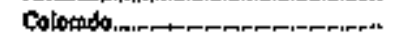 & .2 & .1 & 2 & 3 & 3.7 \\
\hline 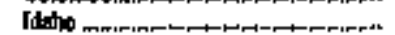 & .2 & 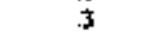 & $i$ & 6 & 2.7 \\
\hline 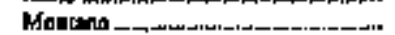 & .7 & 6 & 8 & 4 & 1.8 \\
\hline 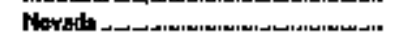 & 3 & .1 & . & .7 & 1.2 \\
\hline Nkw Merico:............................. & 5 & A & 5 & 1.1 & 9 \\
\hline 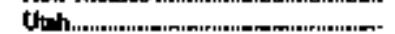 & 2 & .1 & 4 & -I & .7 \\
\hline 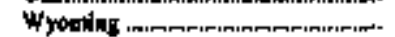 & 4 & .2 & 4 & 2 & 4.3 \\
\hline Padit Cantiguous & 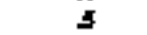 & 3 & 9 & 1.0 & 1.6 \\
\hline Collifomilh, & .6 & $A$ & 1.1 & 12 & 2.4 \\
\hline 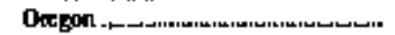 & 6 & .7 & .7 & 1.0 & 3.5 \\
\hline 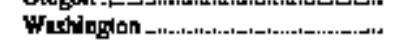 & 5 & d & 3 & 5 & 1.1 \\
\hline Patific Noweontigroun..................... & I & \pm & 2 & 3 & 38 \\
\hline Aletko _._. & 4 & $\overline{3}$ & .4 &. & 53 \\
\hline 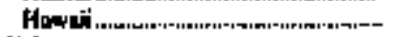 & .1 & .1 & .1 & .1 & .2 \\
\hline 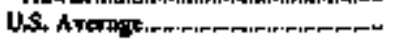 & .1 & 1 &. & .1 & 3 \\
\hline
\end{tabular}

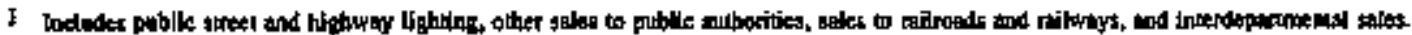

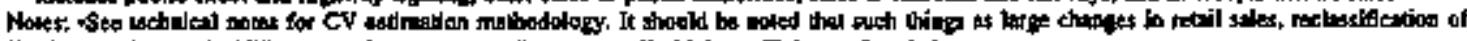

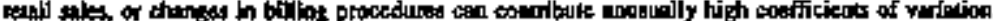

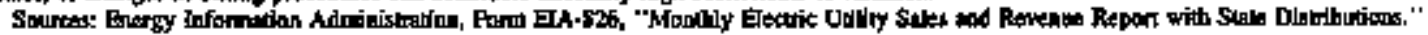





\section{Appendix A}

\section{Technical Notes}

\section{Data Sources}

The Electric Powser Annual ts prepared by the Coal and Electric Data and Renewables Division; Office of Coal, Nudear, Electric and Alternate Fuels; Energy Information Administration (BIA); U.S. Department of Energy (DOE). Data published in the Electric Pourer Annusl Voltume I (EPA) are compiled from three statistical forms filed monthly and two forms filed anmually by electric utilities. Those forms are: the Form EIA-759, "Monthly Power Plant Report"; the Federal Energy Regulatary Commission (FERC) Form 423, "Monthly Report of Cost and Quality of Furels for Electric Plants"; the Form EIA-826, "Monthly Electric Utility Sales and Revenue Report with State Distributions ${ }^{n}$; the Form EIA-861, "Annual Electric Utilly Reporr"; and the Form ELA-860, "Annual Electric Generator Report." Each form is summarized below.

\section{Form ElA-759}

The Form EIA-759 is a mandatory survey of operators of electric utility plants producing electric power for public use. The Form EIA-759 is used to collect monthly data on net generation, consumption of coal, petroleum, and natural gas; and end-of-the-month stocks of coal and petroleum for a sargple of plants by fuel-type and State. Remaining plants are surveyed annually to fom an annual census of all plants. Summary data from the form. ElA-759 are also published in the Electrit Power Monthily (EPM), the Monthly Eneroy Revien (MER), and the Arnual Energy Review (AER). These reports present aggregated date for electric utilities at the U.S., Census division, and North American Electric Reliability Counctl Regton: (NERC) levels.

Instrument and Design Filstory. Prior to 1936, the Bureau of the Census and the U.S. Geological Survey collected, compiled, and published data on the electric power incustry. In 1936, the Federal Power Commission (FPC) assumed all data collection and publication responsibilities for the electric power industry and implemented the FPC Form 4. The Federal Power Act, Sections 311 and 312, and EPC Order 141 define the legislative authority to collext power production data. The Form ElA-755 replaced the FPC Form 4 in January 1962.
Data Processing. The Form BiA-759, along with a teturn envelope, is malled to respondents approximately 4 working days before the end of the month. The respondents names are obtained from a computerized mailing address file. The completed forms are to be returmed to the EiA by the 10th working day after the end of the reporting month. After receipt, data from the completed forms are manually logged in and edited before being keypunched for automatic data processing. An edit program checks the data for errors not found curing ranual editing. The electric uttlity companies are telephomed to obtain data in cases of missing reports and to verify data when questions arise during editing. Following EIA approval, the data are made avallable for pablic use.

\section{FERC Form 423}

The FERC Form 423, a restricted census, is a monthly recond of delivered-fuel purchases, submitted by approximately 230 electric utilities for each plant with a total steain-electric and combined-cycle nameplate capacity of 50 or more megawatts. Summary data from the FERC Form 423 are also published in the EPM and the MER, These reports present aggregated data on electric utilities at the U.S. and Cersus division level.

Instrument and Degign History. On July 7, 1972, the FPC issued Order Number 453 enacting the New Code of Federal Regulations, Section 141.61, legally creating the Form 423. Otiginally, the form was used to collect data orly on fossil-steam plants, but was amerded in 1974 to include data on internal combustion and combustion turbines. The FERC Form 423 replaced the FPC Form 423 in Jantary 1983. Peaking units were eliminated from the FERC Form 423. In addition, the nameplate capacity threshold was changed from 25 megawatts to 50 megawatts. This reduction in coverage eliminated approximately 50 utilities and 250 plants.

In 1991, the FERC Form 423 was amended to include combined-cycle generating units. This increase in coverage added 5 efectric utilities and approximately 15 additional electric plants. Several plants, already reporting on the BERC Form 423, began including fuel receipts for combired-cycie urits starting with 1991 data. 
Daka Processing, Starting with the January 1993 data, the FERC began collection of the data directly from the respondents. The FERC processes the data through edits and each month provides the EIA with a diskette containing the data. The ELA reviews the data for accuracy. Following EIA approval, the data are made available for public use.

\section{Form EIA-826}

The Form EIA-826 is a monthly collection of data from 252 U.S. electric utilities, which generally account for the largest share of retail sales within the State for which they report.

Instrument and Design History. The collection of electric power sales, revenue, and income data began in the early 1940 's and was established as FPC Form 5 by FPC Order 141 in 1947. In 1980, the report was revised with only selected income items remaining and became the FERC Form 5. The Form ELA-626 replaced the FERC Form 5 in January 1983. In January 1987, the Form ELA-826 was changed to the "Monthly Electric UJility Sales and Revenue Report with State Distributions; ${ }^{\prime}$ it was formeriy titled, "Electric Utility Company Monthly Statement" The Form ElA-826 was revised in January 1990, and some data elements were eliminated.

Frame. The current sample for the Form ELA-826, which was designed to obtain estimates of electricity sales and revenue per kilowatthour at the State level by end-use sector, was chosen to be in effect for the January 1993 data. The frame for the Form ELA-826 was originally based on the 1989 submission of the Forr ELA-861, which consisted of approximately 3,250 electric utilities selling retail and/or sales for resale. Note that for the Form ELA-826, we are orly interested in retail sales and reverue. Updates have been made to the frame to reflect Fiergers that affect data processing. Some electric utilities serve in more than one State. Thus, the State-service area is actually the sampling unit. For each State served by each utility, there is a utiltty State-part, or "State-service area." This approach allows for an explicit calculation of estimates for State, Census division, and U.S. level sales, revenue ard revenue per kilowatthour by end-use sector (residential, commercial, industrial and other). A mode]-based cutoff sample is used currently. Regressor data came from the Form EIA-861. (Note that estimates at the "State level" are for soles for the entire State, and similarly for "Census division" and "U.s." levels.)

The preponderance of electric power gales to ultimate consumers in each State are made by a few large utilibies. karking of electric ualities by retail sales on a Stak-by-State basis revealed a consistent pattern of dominance by a few electric uttlites in nearly all 50 States and the District of Columbia. These dominimt electric utilities were selected as a model sample. These electric utilities constitute about 8 percent of the population of U.S. electric utilities, but provide three-quarters of the total U.S. retail electricity sales. The procedures used to derive electricity sales, revenue, average revenue per kilowatthour, and associated coefficient of variation (CV) estimates are provided in the Formutas and Calculations section of this Apperydix.

Data Processing. The forms are mailed each year to the electric utilities with State-parts selected in the sample. The completed form is to be retumed to the EIA by the last calendar day of the month following the reporting month. Norrespondents are telephoned to obtain the data. Imputation, in model sampling, is an implicit part of the estimation. That 1s, data that are not available either because they were not part of the sample or because the data are missing are estimated using a model. The data are edited and entered into the computer where additional checks are completed. After all forms have been received from the respondents, the final aukomated edit is subnitted. After EIA approval, the data are made available for public use.

\section{Form E/A-861}

Data for the Form EIA-861 are collected at the utility level from all electric utilities in the United States, its verritories, and Puerto Rico. Form ELA-861 data in tuis publication are for the United States orly. These data are then aggregated to provide geographic totals at the State, NERC region, Census division, and national level. Sources and disposition of data are also provided by utility class of ownership and retail consumer class of service. Average revenue (nominal dollars) per kilowatthour of electricity sold is caictiated by dividing total annual retail revenue (nominal dollars) by the total annual retail sales of electricity.

Average revenue per kilowatthour is defined as the cost per unit of electricity sold and is calculated by dividing retail electric revenue by the corresponding sales of electricity. The average revenue per kilowatthour is caleulated for all consumers and for each sector (residential, commercial, industrial, and other sales).

Electric utilities typically employ a number of rate schedules within a single sector. These alternative rate schedtules reflect the varying consumption levels and pattens of consumers and their associated impact on the costs to the electric utitity for providing electrical service. The average revenue per kilowathour reported in this publiçation by sector represents a weighted average of 
corsumer revenue and sales within that sector and across sectors for all consumers.

The electric revenue used to derive the average revenue per kilowatthour is the operating revenue reported by the electric utility. Operating revenue indudes energy charges, demand charges, consumer service charges, environmental surcharges, hiel adjustments, and other riscellaneous charges.

Electric utiflty operating revenues cover, among other costs of service, state and Federal income taxes and taxes other than income taxes paid by the utility. The Federal component of these taxes are, for the most part, "payroll" taxes. State and local atthorities tax the value of plant (property taxes), the amount of tevenues (gross receipts taxes), purchases of materials and services (sales and use taxes), and a potentially long list of other items that vary extensively by taxing authority. Taxes deducted from employees' pay (such as Federal income exes and employees' state of social security taxes) are not a part of the utility's "tax costs," but are paid to the taxing authorities in the name of the employees. These taxes are Inclutied in the utlity's cost of service (for example, revenue requirements) and are included in the amounts recovered from consumers in rates and reported in operating reverues.

Ekectric utilities, like many other business enterprises, are required by various taxing authorities to collect and remit taxes assessed on their consumers. In this regard, the electric utility serves as an agent for the taxing atthority. Taxes assessed on the consumer, such as a gross receipts tax or sales tax, are called "pass through" taxes. These taxes do not represent a cost to the utility and are not recorded in the operaking reverues of the uttlity. However, taxing authotities differ as to whether a specific tax is assessed on the utility or the consumer-which, in turn, determines whether or not the tax is included in the operating revetue of the electric utility.

\section{Form EIA-B60}

The Form EIA-860 is a mandatory census of electric utili ties in the United States that operate power plants or plan to operate a power plant within 10 years of the reporting year. The survey is used to collect data on existing power plants from the electric utilities and their 10-year plans for constructing new plants, and modifying and retiring existing plants. Data on the sturvey are collected at the generating undt level. These data are then aggregated by energy source, geographic area, and prime mover. Final data from the Form EfA-860 are also summarlzed in the Inventory of Power Plants th the Linited States.
Instrument and Design History. The Form ELA-860 was implemented in January 1985 to collect data as of year-end 1984. The Federal Energy Administation Act of 1974 (Public Law 93-275) deffues the legisiative authority to collect these data.

Data Protessing. The Form EIA-860 is mailed to approximately 900 respondents in December of the reporting year and the completed forms are to be returned to the EIA by February 15 containing data as of January 1 of the following year. Effective with the 1996 reporting, respondents have the option of filing Form EIA-B60 directly with the EIA or through an agent-such as the respondent's regional electric reltability council. Data reported through the regional electric reliability councils are submitted to the EIA electronicaily from the North American Electric Reliability Councti (NERC). Data for each respondent are preprinted from the applicable data base. Respondents are instructed to verify all preprinted data and to supply missing data. The data are manually edited before being keyed for automatic data processing. Computer programs containing additional edit checks are rtm. Respondents are telephoned to obtain correction ot clariffcation of reported data and to obtain missing data, as a result of the manual and automate editing process. After EIA approval, the data are made available for public use.

\section{Quality of Data}

The Office of Coal, Nuclear, Electric and Alternate Fuels (CNEAF) is responsible for routine data improvement and quality assurance activities. All operations in this office are done in accordance with formal standards established by the EIA. These standards are the measuring rod necessary for quality statistics. Data improvement efforts indude verification of data-keyed input by automatic computerized methods, editing by subject matter specialists, and follow up on nomrespondents. The CNEAF office supports the quality assurance efforts of the data collectors by providing advisory reviews of the structure of information requirements, and of proposed designs for new and revised data collection forms and systems. Once implemented, the actual performance of working data collection systerns is also validated. Computerized respondent data files are checked to identify those who fail to respond to the survey. By law, nonrespondents may be fined or otherwise penalized for not filing a mandatory EiA data form. Before invoking the law, the ELA tries to obtain the required information by encouraging cooperation of nonrespondents.

Completed forms received by the CNEAF offlce are sorted, screened for completerness of reported information, and keyed onto computer tapes for storage and transfer to 
random access data bases for computer processing. The information coded on the computer tapes is manually spot-checked against the forms to certify accuracy of the tapes. Toensure the quality standards established by the ELA, formulas that use the past history of data values in the data base have been designed and implemented to check data triput for errors automatically. Data values that fall outside the ranges prescribed in the formulas are verffied by telephoning respondents to resolve any discrepancles. It is very important, kowever, to concentrate on accuracy in the eartiest stages of data collection. The data quallty community now recogrizes that editing can only be used to find the Jargest errors. Trying to "correct" smaller errors can lead to substantial bias. (Please consult http://www.dataquality.com and other dat qualizy resource references.)

Conceptual problems affecting the quality of data are discussed in the report, An Assessment of the Quality of Selected ELA Data Series."2

\section{Data Editing System}

Data from the form sturveys are edited using automated systems. The edit indudes both deterrrinistic checks, in which records are checked for the presence of required fields and their validity, and statistical checks, in which estination techriques are used to validate data according to their belsavior in the past and in comparison to other current fields.

\section{Rounding Rules for Data}

Given a number with $r$ digits to the left of the decimal and $d+t$ digits in the fraction part, with $d$ being the place to which the number is to be rounded and $t$ being the remaining digits which will be trumcated, this number is rounded to $\mathrm{r}+\mathrm{d}$ digits by adding 5 to the $(\mathrm{r}+\mathrm{d}+1)$ th digit when the number is positive or by subtracting 5 when the number is negative. The $t$ digits are then truncated at the $(r+d+1)$ th digit. The symbol for a rounded number truncated to zero is (").

\section{CNEAF Data Revision and Policy}

The Office of Coal, Nuclear, Electric and Altemate Fuels has adopted the following policy with respect to the revision and correction of recurrent data in energy publications:

1. Annual survey data collected by this office are published either as preliminary or final when first appearing in a data report. Data initially released as preliminary will be so noted in the report. These data will be revised, if necessary, and deciared final in the next publication of the data.

2. All monthly and quarterty survey data collected by this offlce are published as preliminary. These data are sevised only after the completion of the 12-month cycle of the data. No revisions are made to the published data before this unless approved by the Office Director.

3. The magnifude of changes due to revisions experienced in the past will be included in the data repors, so that the reader can assess the accuracy of the data.

4. After data are published as final, corrections may be made in the event of a greater than one percent difference at the national level. Corrections for differences that are less than the before-mentioned threshold are left to the discretion of the Office Director.

This report presents the most ctirrent annulal data avaitable to the EIA. The statistics may differ from those published previously in ELA publications due to corrections, revisions, of other adjustments to the data subsequent to its original release.

On a chapter basis, the status of the data contained in this report is:

- Generating Capability at U.S. Electric Utilities Total net summer capability data from the Form EIA- 860 are preliminary in this publication. Final date will be repotted in the Intentory of Power Plants on the United States.

- Net Generation at U.S. Electric Utilities The Form ExA-759 date are supplemented ennually to become a census, and are final in this report. A comparison of preliminary versus final data is provided in the Techrical Notes of the Electric Pouser Monthly (EPM), when available.

- U.S. Electric Utility Fossil-Fuel Statistics All FERC Form 423 data are final. A comparison of preliminary versus final data is provided in the Technical Notes of the EPM, when available.

- U.S. Elechric Utility Retatl Sales, Revenue, and Average Revenue per Kilowatthour Values for sales, revenue, and average reverue per kilowatthour from the Form ETA-826 are

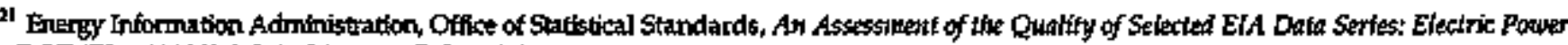
Data, DOE/EA-0292(3) (Washington, DC, 1989). 
preliminary. Historical annual data from the Form EIA-861, "Anunual Electric Utility Report," are final.

\section{Formulas and Calculations}

Average Heat Content. In order to detertsine the Btu value per tanit of consumption for each of the fossil fuels collected on the Form ELA-759, the heat content values contrained on the FERC Form 423 were used. Data on the FERC Form 423 represent approximately 85 percent of the total generator nameplate capacity for all electric utilities.

Percent Difference. The following formula is used to calculate percent differences.

Percent Difference $=\left(\frac{x\left(t_{2}\right)-x\left(t_{1}\right)}{x\left(t_{1}\right)}\right) \times 100$,

where $x\left(t_{7}\right)$ and $x\left(t_{2}\right)$ denote the quantity at year $t_{7}$ and subsequent year $\mathrm{E}_{2}$.

\section{Form EIA-759}

Dat for the Form EIA-759 are collected at the plant level. These data are then aggregated to provide geographic totals at the State, Census division, and U.S. level, or totals by type of plant. Consumption of fuel(s) is converted from quantities (in short tors, barrels, or thousand cubic feet) to Btu at the plant level. End-of-month futel stocks for a single generating plant may not equal beginning-of-the-month stocks, phus IEecipts, less consumption, for many reasons, including the fact that several plants may share the same fuel stock.

\section{FERC Form 423}

Data for the FERC Form 423 are collected at the plant level These data are then used in the following formulas to produce aggregates and averages for each ftrel type at the State, Census division, and U.S. level. For these formulas, receipts and average heat content are at the plant level. For each geographic region, the stummation, $\Sigma$, represents the sum of all plants in that geographic region. Additionally,

- For coel, units for receipts $(R)$ are in tons, urits for average heat content $(A)$ are in Btu per pound, and the unit conversion (U) is 2,000 pounds per ton;

- For petroleum, urits for receipts $(R)$ are in barrels, units for average heat content $\langle A\rangle$ are in Btu per galion, and the urit conversion (W) is $\mathbf{4 2}$ gallons per barrel;
- For gas, units for recetpts $(R)$ are in thousand cubic feet (Mcf), average heat content ( $A$ ) are $\ln$ Btu per cubic foot, and the unit conversion ( $U$ ) is 1000 cubic feet per Mcf.

Where $i$ denotes a plant; $R_{r}=$ receipts for plant $i_{f} A_{i}=$ average heat content for receipts at plant $i$; and, $U=$ unit conversion:

Total $\mathrm{B}_{\mathrm{tu}}=\sum_{i}\left(R_{i} \times A_{i} \times U\right)$,

and

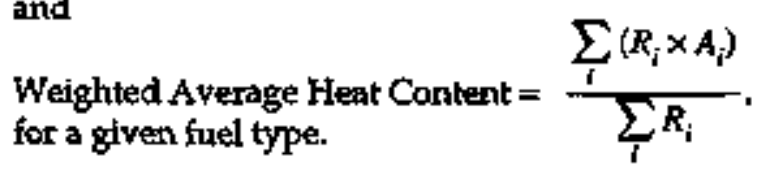

Where $i$ denotes a plant $\mathbb{K}_{1}=$ receipts for plant i; $A_{\text {, }}=$ average heat content for recelpts at plant $i_{i}$ and $C_{i}=$ cost at plant $i$ in cents per million Btu;

Weighted Average Cost (cents per rrillion Btu) =

$$
\frac{\sum_{i}\left(R_{i} \times A_{i} \times C_{i}\right)}{\sum_{i}\left(R_{i} \times A_{i}\right)}
$$

and

Weighted Average Cost (dollars per unit) =

$$
\frac{U \sum_{i}\left(R_{i} \times A_{i} \times C_{i}\right)}{(10)^{2} \sum_{i} R_{i}}
$$

\section{Form E/A- 126}

The Form ELA-826 data are collected at the utility level by end use sector and State. When a utility has sales in more than one State, the data that may be required are dependent upon the sample selection that was done for each State. Data from the Form EIA-826 are used to determine estimates by sector at the State, Census division, arki national level for the entire corresponding State, Census division, or nationtal category. Form EIA-861 data were used as the frame from whtch the sample was selected, and also as regressor data.

A cutoff model sample is used, so that only utilities that have relatively lange sales in one or more end use sectors in a given State were selected. The sample consists of 252 electric utilites. This includes a somewhat larger number of State-rice areas for electric utilities Estimation procedures indude imputation to account for nonresponse. State-level sales-and-revenuse estimates are calculated. Also, a ratio estimation procedure is used for 
estination of average revenue per kilowatthour at the State level. These estimates are accumulated separately to produce estimates for Cersus division and U.S. levels.

The coefficient of variation (CV) statistic, usvally given as a percent, is an estimate that describes the magntude of sampling error that might reasonably be incurred. The $\mathrm{CV}$, sometimes referred to as the relative standard errox, is the square root of the estimated relative variance of the variable of interest. The variable of interest may be a single vartable (for example, sales) or it may be the ratio of two variables (for example, revenue to sales).

CV's were not specifically designed to account for nonsampiling errors, such as errors of misclassfffcation or transposed digits. They are, however, affected by nonsampling errors. Using the Central Limit Theorem, which applies to sums and means, there is an approximate 68-percent chance that the true sampling error is less than the corresporxding $\mathrm{CV}$, when there is no nonsampling error. In reality, a large CV often is caused by a lange nonsampling error that the system has failed, up to that point, to correct. Several large nonsampling errors have been found this way.

As an example of an ordinary application of $\mathrm{CV}$ s, suppose that a revernue-per-kilowathour value is estinated to be 5.13 cents per kilowatthour with an estimated CV of 1.6 percent. This means that, ignoring any nonsampling error, there is appronimately a 68-percent chance that the true average revenue per kilowatthour is within approximately 1.6 percent of 5.13 cents per kilowatthour (that is, between 5.05 and 5.21 cents per kilowathour $\rangle$. There is approximately a 95-percent chance of a true sampling error being $2 \mathrm{CV}$ 's or less.

For sales or revenue in any sector at the State level, if we let $x$ represent an observation from the Form E[A-861, y represents an observation from the Form EIA-826, and $\hat{y}$ represents an estimated vatue for data not collected, then

$y_{f}=b x_{i}+x_{i}^{Y} \varepsilon_{\theta_{1}}$

$\hat{y}_{i}=\hat{b} x_{i}$,

$\hat{b}(\gamma)=\left[\sum_{k=1}^{n} x_{k}^{1-\nu_{y}} y_{k}\right] /\left[\sum_{k=1}^{4} x_{k}^{2-2 y}\right]$
Here, $\mathrm{n}$ is the Form ELA-826 sample size for that State, and $b$ is the factor ('slope') relating $x$ to $y$ in the linear regression. $Y$ is taken to be $1 / 2$ although more research could refine this. For the Form ELA-826, $\gamma=1 / 2$ has been shown to be robutst.

CV etmates may also be provided for annualized estimates of sales and revenue. These CV estimates may be biased to larger than actual values, in general, because covariances between the various months of data are ignored. Even so, many of these estimates are less than one percent, and the national level estimates are quite small. Also, note that experience with past test data indicates that when CV estimates are only a few tenths of a percent, they may often be biased high even before aggregation (However, the opposite may be true for somewhat larger CVs.) Thus, these $\mathrm{CV}$ estimates, especially at the national level, are likely to be over estimated. Further, $\mathrm{CV}$ estimates, although designed to measure sampling error, are impacted by nonsampling error. This along with information given in the Electric Potoer Monthly (EPM) Table B2, "Comparison of Preliminary Versus Final Published Data at the U.S. Level," and Table B4, "Comparison of Sacmple Versus Census Published Data at the U.S. Level by End-Use Sector." give a fairly good indication of overall data accuracy.

Sales and revenue data are expected, generaliy, to be highly positively corretated, and when estimating CV's for average revenue per kilowatthour, that covaríance should not be ignozed ${ }^{2}$ A covariance formula to handle this was developed by Professor Poduri S.R.S. Rao.

(For additional techudcal information, see the EPM, April 1995, page 254).

\section{Form E14-860}

Data for the Form ELA-860 are subnitted at the generating unit level and then aggregated by energy source, prime mover, and geographic area. Estimated values for net summer and net winter capability for nonnuclear etectric generating units were developed by use of a regression formula, using year-end 1992 data on net summer capability, net winter capability, and generator nameplate capacity of units in commercial operation during three fintervals of tine: 1940 or earlies, 1941 through 1980, and 1981 to present. $^{2}$

\footnotetext{
22 Thts model is discussed inK'naub, J.R., Jr. (1994), "Relative Standard Error for a Ratio of Vartables at an Aggregate Levet Under Model Sampling," Procedings of the Section on Survey Reserrch Methods, Pp. 310-312, American Statistical Association.

${ }^{2}$ Respondents report summer and winter capability and nameplate for all nuclear units.
} 
A heterogeneous, zero-intercept linear regresston model with generator nameplate capacity (expressed in kilowatts) as the regressor data was used since examination of the data shows that the intercepts are generally near zero. $^{212}$

In all formulas, the symbol, ${ }^{*}$ is an operator meaning multiplied by.

For nonuuclear units,

Nef Capability $=b^{*}($ Nameplate Capaciry),

where

b, represents the slope or factor by which nameplate capacity has to be multiplied to obtain a capabiltity estimate.

Using this model in the following,

$\delta$ represents the standard error for $b$.

\section{Net Summer Capability}

$b=.90,8=.04,1940$ or eartiler; $b=.927,8=.002$, $1941-1980 ; b=.937, \delta=.004,1981$ through present, for coal steam units (Unit Types, ST, AB, PB)

$\mathrm{b}=1.00, \delta=.03,1940$ or earlier; $\mathrm{b}=.961,8=.002,1941-$ $1980 ; \mathrm{b}=.93,8=.01,1981$ through present, for noncoal steam units (Unit Types, ST, AB, PB)

$b=.856, \delta=.003,1980$ or earlier; $b=.85, \delta=.01,1981$ through present, for gas-turbine units (Unit Types, GT, JE).

$\mathrm{b}=94, \delta=01,1940$ or earlier, $b=.84, \delta=.01,1941-1980$; $\mathrm{b}=86, \mathrm{\delta}=, 02,1981$ through present, for combined-cycle units (Unit Types, CA, CS, CW, CT, IG)

$\mathrm{b}=\$ 884,8=.009,1940$ or eartier; $\mathrm{b}=.925,0=.002,1941$ $1980 ; \mathrm{b}=.976,0$ = .003, 1981 thưough present, for internal combustion units (Unit Type, IC)

$b=.975, \delta=.005,1940$ or earlier; $b=1.034, \delta=.004,1941$ - 1980; $b=.950,0=.008,1981$ through present, for conventional and pipeline hydroelectric uruts (Unut Types, $\mathrm{HC}, \mathrm{HL})$ $b=.93, \delta=.08,1940$ or earlier; $b=1.03, \delta=.01,1941$ $1980 ; b=1.01,8=.006,1981$ through present, for pumped-storage hydroelectrtc units (Unit Type, HR)

$\mathrm{b}=1$, for all other units (Induding Unit Types, CG, FC, $\mathrm{GE}, \mathrm{OC}, \mathrm{SP}$, S, $\mathrm{WT})$, where linited data are available.

\section{Net Winter Capability}

$b=.88, \delta=.05,1940$ or eartier; $b=.934, \delta=.002,1941$ $1980 ; \mathrm{b}=.940, \delta=.004,1981$ through present, for coal stean units (Unit Types, ST, AB, PB)

$\mathrm{b}=1.02, \mathrm{~d}=.03,1940$ or earlier; $\mathrm{b}=.965, \delta=.002,194 \mathrm{~L}-$ $1980 ; b=.94, \delta=.01,1981$ through present, for moncoal steam units (Unit Types, ST, AB, PB)

$b=\mathbf{i} .023,8=.004,1980$ or earliet; $b=98, b=.01,1981$ throught present, for gas-turtine units (Unit Types, GT, JE)

$\mathrm{b}=1.02,8=.03,1940$ or earlier; $\mathrm{b}=.96,8=.01,194 \mathrm{l}$. $1980 ; b=.94, \delta=.02,1981$ through present, for combined-cycle units (Unitt Types, CA, CS, CW, CT, IG)

$\mathrm{b}=.893, \mathrm{~b}=.006,1940$ or earlier, $\mathrm{b}=.940,8=.002,1941$ $-1980 ; \mathrm{b}=.987,8=.002,1981$ through present, for internal combustion units (Unit Type, IC)

$\mathrm{b}=, 979,8=.005,1940$ or earijer; $\mathrm{b}=1.026,6=.004,1941$ - 1980; b = .92, $\mathrm{z}=01,1981$ turough present, for conventional and pipeline hydroelectric units (Unit Types, $\mathrm{HC}, \mathrm{HL}$ )

$b=.96,8=.05,1940$ or earlfer; $b=1.02,8=.01,1941$ $1980 ; \mathrm{b}=1.03,8=.01,1981$ through present, for pumped-storage hydroelectric units (Unit Type, HR)

$b=1$, for all other units (Unit Types, FC, GE, OC, SP, SS, WT, CG), where limited data are available.

\section{General Information}

\section{Use of the Glossany}

The terms in the glossary have been defined for general use. Restrictions on the definitions as used in these data collection systems are included in each defirition when necessary bo define the terms as they are used in this report.

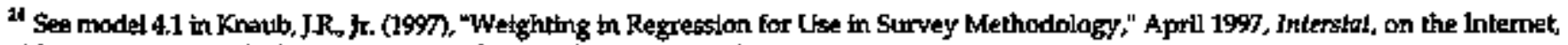
hitp:/ / interstatsiat,vt.edu/Interstat, shown here under Form झlA-826.

${ }^{25}$ For a more general formuls for the related egtimate of the tobal, " $T_{x}$ see section 4 of "Weighted Multiple Regresion Egtination for Survey Model Sampling" May 1996, Interstat, on the Intemet, hitpt/ fintemstat stat vitedu/Interstat.
} 
Table A1. Unit-of-Measure Equivalents:

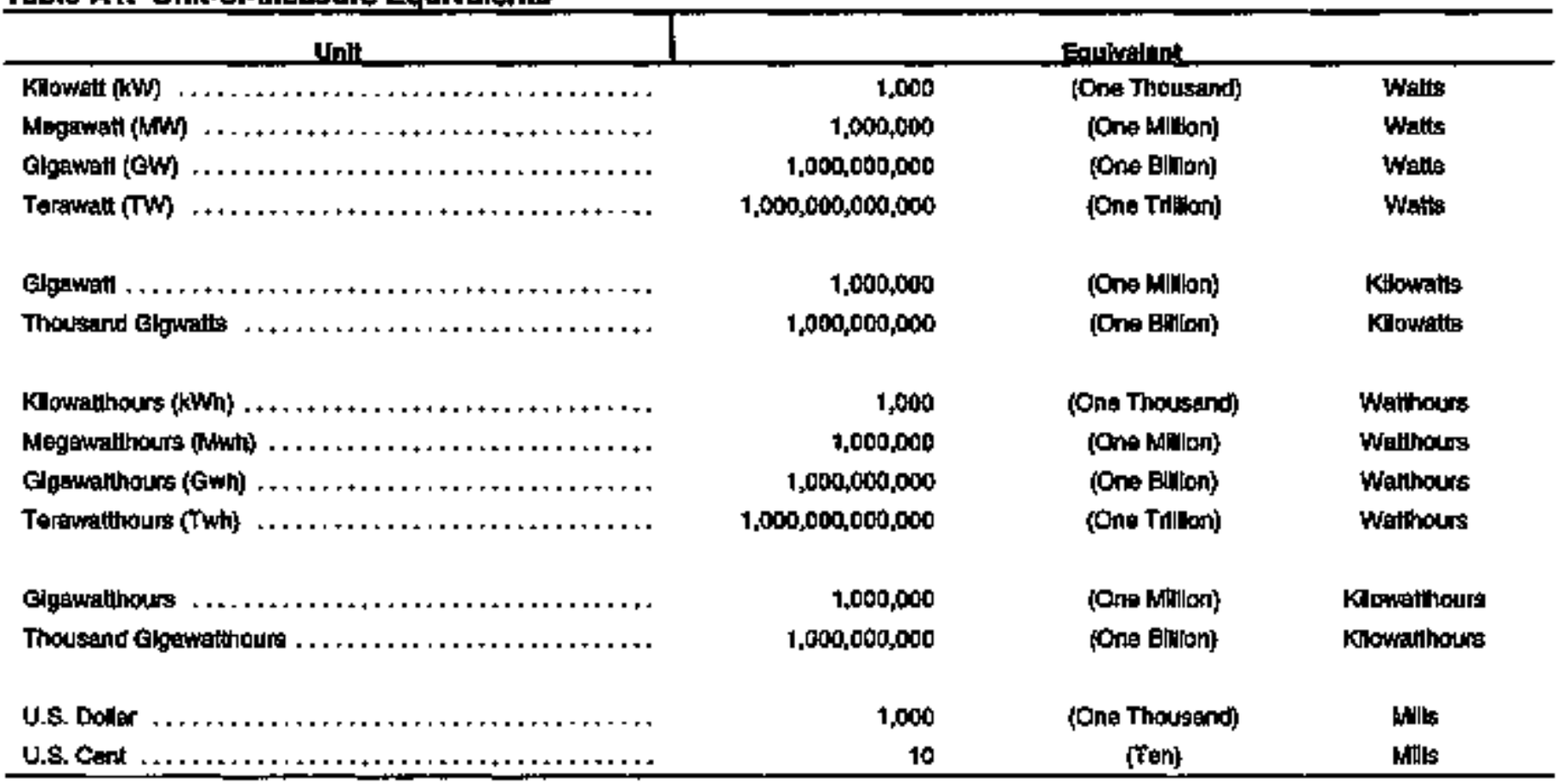

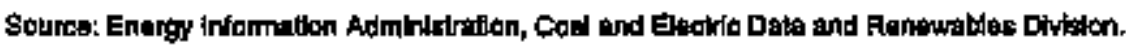

Table A2. Metric Comversion

\begin{tabular}{|c|c|c|c|c|c|}
\hline $\begin{array}{c}\text { Type of } \\
\text { Unlt }\end{array}$ & U.6. Unil & mullipitiod by & comuralon Factox & equarils & Metrie Un! \\
\hline \multirow[t]{2}{*}{ Mass } & short tens $(2,000 \mid b)$ & $\mathbf{x}$ & 0.9071847 & $=$ & metriv tons (t) \\
\hline & pounds (b) & $\mathbf{x}$ & 0.45059237 & $=$ & klogeme (kds) \\
\hline \multirow{2}{*}{ Volume } & cuble fast ( $(A)$ & $\boldsymbol{x}$ & 0.02831685 & $=$ & abic moters $\left(\mathrm{m}^{*}\right)$ \\
\hline & U.S. oallone (ga) & $x$ & 3,795412 & $=$ & thers (L) \\
\hline Energy & 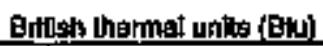 & $x$ & 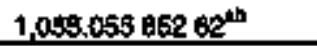 & $=$ & joutes (J) \\
\hline
\end{tabular}

Exact comvertion.

"The Btu used in this table is the Inlematonal Table Btu adopled by the Fifih Inlemational Conterenee on Preperties of Sieam, Lendor, 1958.

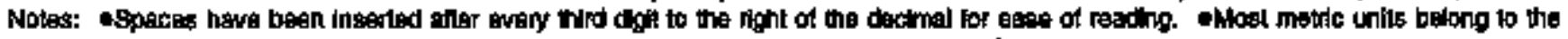

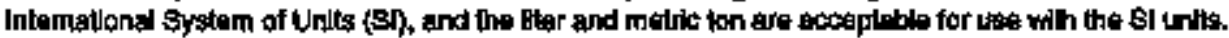

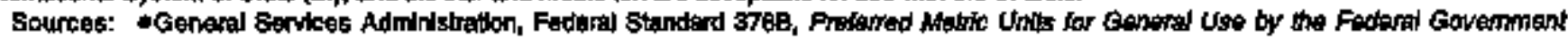

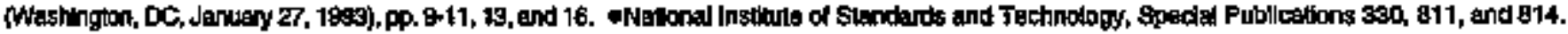

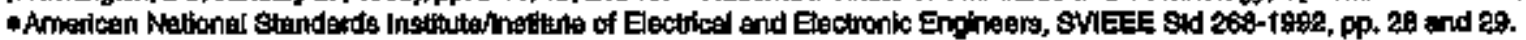




\section{Glossary}

Acid Raln: Also called actd precipitation or acid deposition, acid tain is precipitation containing hatmful amounts of nitric and sulfuric acids tormed primarily by nitrogen oxddes and sulfur oxades released into the atmosphere when fossil fuels are burned. It can be wet precipitation (rain, srow, or fog) or dry precipitation (absonbed gaseous and particulate matter, aerosol partides or dust). Add rain has a pH below 5.6. Nomal rain has a pH of about 5.6, which is slightly acidic. The term $\mathrm{pH}$ is a measure of acidity or alkalinity and ranges from 0 to 14. A pH measurement of 7 is regarded as neutral Measurements below 7 indicate increased acidity, while those above indicate increased alkalinity.

Ampere: The urit of measurement of electrical current produced in a circuit by 1 volt acting through a resistance of $1 \mathrm{ohm}$.

Anthracite A hard, black lustrous coal, often referred to as hard coal, containing a high percentage of fixed carbon and a low percentage of volatile matter. Comprise three groups dassifled accorcting to the following ASTM Spectilication D388-84, on a dry mineral-matter-free basis:

$\begin{array}{llccr} & \begin{array}{l}\text { Fixed } \\ \text { Carbon } \\ \text { Limits }\end{array} & \begin{array}{l}\text { Volatile } \\ \text { Matter }\end{array} \\ & \text { GE } & \text { LT } & \text { GT } & \text { LE } \\ \text { Meta-Anthracite } & 98 & - & - & 2 \\ \text { Anthracite } & 92 & 98 & 2 & 8 \\ \text { Semianthracite } & 86 & 92 & 8 & 14\end{array}$

Ash: Impurities consisting of silica, iron, alumina, and other noncombustible matter that are contained in coal. Ash increases the weight of coal, adds to the cost of handling, and can affect its burning characteristics. Ash content is measured as a percent by weight of cosl on an "q.as receivedzeq. or a "dry" (moisture-free, usually part of a laboratory analysis) basis.

Available but not Needed Capability: Net capability of main generating units that are operable but not cor sidered necessary to carry load, and carmot be connected to load within 30 minutes.
Average Revenue per Kilowathour. The average revenue per kilowatthour of electricity sold by sector (residential, commercial, industrial, or other) and geographic area (State, Census division, and natlonal), is calculated by dividing the total monthly revenue by the corresponding total monthly sales for each sector and geographic area.

Barrel: A volumetric unit of measure for cutde oil and petroleum products equivalent to $42 \mathrm{US}$. gallons.

Base Bill A charge calculated through multiplication of the rate from the appropriate electric rate schedule by the level of consumption.

Baseload: The minimum amount of electric power delivered of required over a given period of time at a steady rate.

Baseload Capacity: The generating equipment norrally operated to serve loads on an around-the-clock basis.

Baseload Plant: A plant, usually housing high-efficiency steam-electric units, which is nonnally operated to take all or part of the mirimtm load of a system, and which consequently produces electricily at an essentially constant rate and runs continuously. These untis are operated to moximize system mechanical and therma! efficiency and minimize system operating costs.

BbL: The abbreviation for barrel.

Bcf: The abbreviation for 1 billion cubic feet.

Bituminous Coal: The most common coal. It is derse and black (often with well-defined bands of bright and dull material). Its moisture content usually is less than 20 percent. It is used for generating electricity, making coke, and space hesting. Comprises five groups classified according to the following ASTM Specification D388-84, on a dry mineral-matter-free (mmf) basis for fixed-carbon and volatile matter and a moist murf basis for calorific value. 


$\begin{array}{lll}\text { Fixed } & \text { Volatile } & \text { Calorific } \\ \text { Carbon } & \text { Matter } & \text { Value } \\ \text { Limits } & \text { Limits } & \text { Limits } \\ & & \text { Btu } / \mathrm{lb}\end{array}$

$\begin{array}{llllcll} & \text { GE } & \text { LT } & \text { GT } & \text { LT } & \text { GE } & \text { LE } \\ \text { LV } & 78 & 86 & 14 & 22 & - & - \\ \text { MV } & 69 & 78 & 22 & 31 & - & - \\ \text { HVA } & - & 69 & 31 & - & 14000 & - \\ \text { HVB } & - & - & - & - & 13000 & 14000 \\ \text { HVC } & - & - & - & - & 10500 & 13000\end{array}$

LV = Low-volatile bituminous coal

MV = Medium-volatile bituminous coal

HVA = High-volatile A bituminous coal

HVB = High-volatile $\mathrm{B}$ bituminous coal

HVC = High-volatile C bituminous coal

Boiler: A device for genterating sterm for power, processing, or heating purposes or for producing hot water for heating purposes or hot water supply. Heat from an external combustion source is transmitted to a fluid contained withtin the tubes in the boller shell. This fluid is delivered to an end-use at a desired pressure, temperature, and quality.

Btu (British Thermal Unit): A standand untit for measuring the quantity of heat energy equal to the quantity of heat recuuired to raise the temperature of 1 pound of water by 1 degree Fahrentheit.

Capability. The maxtmum load that a generating unit, generating station, or other electrical apparatus can carry under specified conditions for a given period of tine without exceeding approved limbts of temperature and stress.

Capacity: The amount of electric power delivered or required for which a generator, turbine, transtormer, transtrission circuit, station, or system is rated by the nanufacturer.

Capacity (Purchased): The arnount of energy and capacity available for purchase fror outside the system.

Capacity Charge: An element in a two-part pricing method used in capacily transactions (energy charge is the other element). The capacty charge, sometimes called Demand Charge, is assessed on the amount of capacity being purchased.

Census Divisions: The nine geographic divisions of the United States established by the Bureau of the Census, U.S. Department of Commerce, for the purpose of statistical aralysis. The boundaries of Census divisions coincide with State boundartes. The Pacific Division is subdivlded into the Pacific Contiguous and Pacific Noncontiguous areas.
Circuit: A conductor or a system of conductors through which electric current flows.

Coal: A black or browniah-black solid combustible substance formed by the partial decomposition of vegetable matter without access to air. The rank of coal, which includes anthracite, bituminous coal, subbitumintous coal, and lignite, is based on fixed carbon, volatile matter, and heating value Coal rank indicates the progressive alteration from ligrite to anthracite. Iignite contains approximately 9 to 17 million Btu per ton. The contents of subbituminous and bituminous coal range from 16 to 24 million Btu per ton and from 19 to 30 million Btu per ton, respectively. Anthracite contains approximately 22 to 28 million Btu per ton.

Cogenerator. A generating facility that produces electricity and another form of useful thermal energy fsuch as heat or steam), used for industrial, commercial, heating, or cooling putposes. To receive stalus as a qualifying facility (QF) under the Public Utility Regulatory Policies Act (PURPA), the facility must produce electric energy and :q.another form of useful thermbl energy through the sequential use of energy; req. and meet certain ownership. operating, and effociency criteria stablished by the Federal Energy Regulatory Commission (FERC). (See the Code of Federal Regulations, Title 18, Part 292.)

Coincidental Demand: The sum of two or more demands that occur in the same time interval.

Coincidental Peak Load: The sum of two or more peakloads that occur in the same time interval.

Coke (Petroleum): A residue high in carbon content and low in hydrogen that is the final product of thermal decomposition in the condensation process in cracking. This product is reported as marketable coke or catalyst coke. The conversion factor is 5 barrels (42 U.S. gallons each) per short ton.

Combined Cycle: An electric generating technology in which electricity is produced from otherwise lost waste heat exiting from one or more gas (combustion) turbines. The exiting heat is routed to a conventional boiler or to a heat recovery steam generator for utilization by a steam turbine in the production of electricity. This process increases the efficiency of the electric generating unit.

Combined Cycle Unit An electric generating unit that consists of one or moxe combustion turbines and one or more boilers with a portion of the required energy input to the boiler(s) provided by the exhaust gas of the combustion turbine(s).

Combined Pumped-Storage Plant: A pumped-storage hydroelectric power plant that uses both pumped water and natural streamflow so produce electricity. 
Commercial: The commercial sector is generally defined as nonmanufacturing business establishments, includting hotels, motels, restaurants, wholesale businesses, retail stores, and health, social, and educational institutions. The utility may classify commercial service as all constumers whose demand or anntual use exceeds some specified limit. The limit may be set by the uttity based on the rate schectule of the utility.

Commercial Operation: Commencial operation begins when control of the bading of the generator is turned over to the system dispatcher.

Consumption (Fuel): The amount of fued used for gross generation, providing standby service, start-up and/or flame stabilization.

Contract Price; Price of fuels marketed on a contract basis covering a period of 1 or more years. Contract prices reflect market conditions at the time the contract was negotiated and therefore remain constant throughout the life of the contract or are adjusted through escalation clauses. Generally, coniract prices do not fluctuate widely.

Contract Receipts: Purchases based on a negotated agreement that generally covers a period of 1 or more years.

Cooperative Electrle Utility: An electric utility legally established to be owned by and operated for the benefit of those using its service. The utility company will generate, transmit, and/or distribute supplies of electric energy to a specifled area not being serviced by another utility. Such ventures are generally exempt from Federal income tax laws. Most electrlc cooperatives have been isitially financed by the Rural Electrification Administration, U.S. Department of Agriculture.

Cost The amount paid to acquire resources, such as plant and equipment, fuel, or labor services.

Current (Electric): A flow of electrons in an electrical conductor. The strength or rate of movement of the electricity is measured in amperes.

Demand (Electric): The rate at which electric energy is delivered to or by a system, part of a system, or piece of equipment, at a given instant or averaged over any designated period of tinite.

Demand-Side Management: The plarring, implementation, and monitoring of utility activities designed to encourage consumers to modify patterns of electricity usage, including the tering and level of electricity demand. It refers only to energy and load-shape modifying activities that are undertaken in response to ublity-adruinistered programs, It does not refer to energy and toad-shape thanges arising from the normal operation of the marketplace or from govemment-mandated energy-efficiency standards. Demand-Side Management (DSM) covers the complete range of load-shape objectives, including strategic conservation ard load management, as well as strategic load growth.

Distillate Fuel Oil: A general classification for one of the petroleum fractions produced in conventionat distillation operations. It is used primarify for space heating, on-and-off-highway tiesel engine fuel (induding railroad engine fuel and fuel for agriculture machunery), and electric power generation. Included are Fuel Oils No. 1, No. 2, and No. 4; and Diesel Fuels No. 1, No. 2, and No. 4.

Distribution System: The portion of an electric system that is dedicated to delivering electric energy to an end user.

Electric Plant (Physical): A facility containing prime movers, electric generators, and auxiliary equipment for converting mechanical, chemical, and/or fission energy into electric energy.

Electric Rate Schedule: A statement of the electric rate and the terms and conditions governing its application, including attendant contract terms and conditions that have been accepted by a regulatory body with appropriate oversite authority.

Electric Utility: A corporation, person, agency, authority, or other legal entity or instrumentality that owns and/or operates facilities within the United States, its territories, or Puerto Rioo for the generation, transmission, distribution, or sale of electric energy primarily for use by the public and files forms listed in the Code of Federal Regulations, Title 18, Part I41. Facilities that qualify as cogenerators or small power producers under the Public Utility Regulatory Polfcies Act (PURPA) are not considered electric utilities.

Energy: The capacity for doing work as measured by the capability of doing work (potential energy) or the conversion of this capability to motion (kinetic energy). Energy has several forms, some of which are easily convertible and can be changed to another form useful for work. Most of the world's convertible energy comes from fossil fuels that are burned to produce heat that is then used as a transfer medium to mechanical or other means in order to accomplish tasks. Electrical energy is usually measured in kilowatthours, while heat energy is usually measured in Britsh thermal urits.

Energy Charge: That portion of the charge for electric service based upon the electric energy (kWh) consumed or billed. 
Energy Deliveries: Energy generated by one electric utlity system and delivered to another system through one or more transmission lines.

Energy Efficiency: Refers to programs that are aimed at reducing the energy used by specific end-use devices and systems, typically without affecting the services provtded. These programs reduce overall electricity consumption (reported in megawathours), often without explict toonsideration for the timing of program-induced savings. Such savings are generally actieved by substituting technically more advanced equipment to produce the same level of end-use services (e.g. lightong, heating, motor drive) with less electricity. Examples inchude high-efficiency appliances, efficient lighting programs, high-efficiency heating, ventilating and air conditioning (HVAC) systems or control modifications, efficient building design, advanced electric motor drives, and heat recovery systems.

Energy Receipts: Energy generated by one electric utility system and received by another system through one or more transmission lines.

Energy Source: The primary source that provides the power that is converted to electricity through chemical, mechanical, or other means. Energy sources include coal, petroleum and petroleum products, gas, water, urandum, wind, sunlight, geothermal, and other sources.

Facility: An existing or planned location or site at which prime movers, electric generators, and/or equipment for converting mechanical, chemical, and/or nuclear energy into electric energy are sifuated, or will be situated. A facility may contain more than one generator of elther the same or different prime mover type. For a cogenerator, the facility includes the industrial or conmercial process.

Federal Energy Regulatory Commission (FERC): A quasi-independent regulatory agency within the Department of Energy having jurisdiction over interstate electricity sales, wholesale electric rates, hydroetectric licensing, natural gas piring, of pipeline rates, and gas pipeline certification.

Federal Power Act Enacted in 1920, and amended in 1935, the Act consists of three parts. The first part incorporated the Federal Water Power Act administered by the former Federal Power Corturission, whose activities were confined almost entirely to licensing non-Federa! hydroelectric projects. Parts II and III were added with the passage of the Public Usility Act. These parts extended the Act's jurisdiction to include regulating the interstate transmission of electrical energy and rates for its gale as wholesale in interstate commerce. The Federal Energy Regulatory Commission is now charged with the administration of this law.
Federal Power Commission: The predecessor agency of the Fedezal Energy Regulatory Cormmission. The Federal Power Comunission (FPC) was created by an Act of Congress under the Federal Water Power Act on June 10, 1920. It was charged originally with regulating the electric power and natural gas industries. The FFC was abolished on Septimber 20, 1977, when the Department of Energy was created. The fuxtions of the FPC were divided between the Department of Energy and the Federal Energy Regulatory Commission.

FERC: The Federal Energy Regulatory Commission.

Firm Gas: Gas sold on a continuous and generally long-term contract.

Firm Power: Power or power-producing capacity intended to be available at all times during the period covered by a guaranteed commitment to deliver, even under adverse conditions.

Flue Gas Desulfurization Unit (Scrubber): Equipment used to remove sulfur oxides from the combustion gases of a boiler plant before dischange to the atmosphere Chemicaks, such as lime, ake used as the scrubbing media.

Flue Gas Partlculate Collectors: Equipment used to remove fly ash from the combustion gases of a boiler plant before discharge to the atmosphere. Particulate collectors include electrostatic precipitators, mechanical collectors (cyclones), fabric filters (baghouses), and wet scrubbers.

Fly Ash: Particule matter from coal ash in which the particle diameter is less than $1 \times 30^{-4}$ moter. This is removed from the flue gas using flue gas particulate collectors stach as fabric filters and electrostatic precipitators.

Forced Outage: The shutdown of a generating unit, transmission line or other facility, for emergency reasons or a condition in which the generating equipment is unavailable for load due to unanticipated breakdown.

Fossil Fuel: Any naturally ocourring organic fuel, such as petroleum, cosil, and natural gas.

Fossil-Fuel Fiant A plant using coal, petroleum, or gas as its source of energy.

Fuel: Any substance that can be burned to produce heat; also, materials that can be fissioned in a chain reaction to produce heat.

Fuel Expenses: These costs include the fuel used in the production of steam or driving another prime mover for the generation of electricity. Other associated expenses include umloading the shipped futel and all handling of 
the fuet up to the point where if enters the first burker, hopper, bucket, tank, or holder in the boller-house stricture.

Full-Forced Outage: The net capability of main generating units that is tmavailable for load for emergency reasons.

Gas: A fuel bumed under boilers and by intermal combustion engines for electric genteration. These include natural, manufactured and waste gas.

Gas Turbine Plant: A plant in which the prine mover is a gas turbine. A gas turbine consists typically of an axial-fiow air compressor, one or more combustion chambers, where liquid or gaseous fuel is butned and the hot gases are passed to the turbine and where the hot gases expand to drive the generator and are then used to run the compressor.

Generating Unit Any combination of physically connected generator(s), reactor(s), boiler(s), combustion turbine(s), or other ptime mover(s) operated together to produce electric pawer.

Generation (Electricity): The process of producing electric energy by transforming other forms of energy; also, the amount of electric energy produced, expressed in watthours (Wh).

Gross Generation: The total amount of electric energy produced by the generating units at a generating station or stations, measured at the generator terminals.

Net Generation: Gross generation less the electric energy consumed at the generating station for station use.

Genevator: A machine that converts mechanical energy into electrical energy.

Generator Namoplate Capadity: The full-load contintous rating of a generator, prime mover, or other electric power production equipment under speciflc conditions as designated by the manufackuret. Installed generator. nameplate rating is usually indicated on a nameplate physically attached to the generator.

Geothermal Plant: A plant in which the prime mover is a steam turbine. The turbine is driven efther by steam produced from hot water or by natural steam that derives its energy from heat found in rocks or fluids at various depths beneath the surface of the earth. The erergy is extracted by drilling and/or pumping.

Gigawatt (GW): One billion watts.

Gigawatthour (GWh); One billion watthours.
Grenhouse Effect The increasing mean global surface temperature of the earth caused by gases in the atmosphere (including catton dioxide, methane, nitrous oxide, ozone, and hiorofluorocarbon). The greenhouse effect allows solar radiation to penetrate but absorbs the infrared radiation returning to space.

Grid: The Jayout of an electrical distribution system.

Gross Generation: The total amount of electric energy produced by a generating facility, as measured at the generator terminals.

Heavy Oil: The fuel oils remaining after the lighter oils have been distllied off during the refining process. Except for stast-up and Fame stabilization, virtually all petroleum used in steam plants is heavy oil.

Hydroelectric Plant; A plant in whith the turbine generators are driven by falling water.

Industrial: The industrial sector is generally defined as manufacturing, construction, mining agriculture, fishtng and forestry establishments Standard Industrial Classification (SIC) codes 01-39. The tutility may classify industrial service using the SIC codes, or based on demand or armual usage exceeding some specifted limit. The limit may be set by the utility based on the rate schedule of the utility.

Intermediate Load (Electric System): The range from base load to a point between base load and peak. This point may be the nudpoint, a percent of the peakload, or the load over a specified time period.

Internal Combustion Plant: A plant in which the prime mover is an internal combustion engine. An internal combustion engine has one or more cylinders in which the process of combustion takes place, converting energy released from the raptd burring of a fuel-air mixture into mecharical energy. Diesel or gas-fired engines are the principal types used in electric plants. The plant is tasually operated during periods of high demand for electricity.

Interruptible Gas: Gas sold to customers with a provision that permits curtailment or cessation of service at the discretion of the distributing company under certain circumstances, as specified in the service contract.

Interruptible Load: Refers to progrant activibies that, in accordance with contractual arrangements, can intertupt consumer load at times of seesonal peak load by direct control of the utility system operator or by action of the consumer at the direct recuest of the system operator. It usually involves commerctal and tondustrial consumers. In some instances the load reduction may be affected by direct actlon of the system operator (remote tripping) after 
notice to the consumer in accordance with contractual provisions. For example, loads that can be interrupted to fulfill plaxuing or operation reserve requirentents should be reported as Interraptible Load. Interruptlble Load as defined here excludes Direct Load Control and Other Load Management. (Interruptible Load, as reported here, is synonymous with Interruptible Demand reported to the North American Electric Reliability Council on the volumtary Office of Energy Emergency Operations Form OE-411, "Coordinated Regional Bulk Power Supply Program Report," with the exception that annual peakload effects are reported on the Form ELA-861 and seasonal (i.e., surmer and winter) peakload effects are reported on the $\mathrm{OE}-411$ ).

Kilowatt (kW): One thousand watts.

Kilowatthour (kWh): One thousand watthours.

Light $O$ id: Lighter fuel oils distitled off during the refining process. Virtually all petroleum used in internal combusstion and gas-turbine engines is light oil.

Lignita: A brownish-black coal of low rank with high inherent moisture and volatile matter (used almost exclusively for electric power generation). If is also referred to as brown coal. Comprise two groups dassified according to the following ASTM Spedfication D388-B4 for calorific values on a moist material-matter-free basis

Limits Bto/lb.

$\begin{array}{lcc} & \text { GE } & \text { LT } \\ \text { Lignite A } & 6300 & 8300 \\ \text { Lignike B } & - & 6300\end{array}$

Load (Electric): The amount of electric power defilvered or required at any specific point or points on a system. The requirement originates at the energy-consuming equipment of the consumers.

Maximum Demand: The greatest of all demands of the load that has occurred wittin a spectifled pertod of time.

Mcf: One thousend cubic feet.

Megawatt (MW): One million watts.

Megawatthour (MWh): One million watthours.

MMcf: One million subic feet.

Natural Gas: A naturally occurring mixture of hydrocarbon and nonhydrocarbon gases found in porous geological formations beneath the earth's surface, often in association with petroleum. The principal constituent is methane.
Net Capability: The maximum load-carying ability of the equipment, exclusive of station use, under specified conditions for a given time interval, independent of the characteristics of the load. (Capability is determined by design characteristics, physical conditions, adequacy of prime mover, energy supply, and operating timútations such as cooling and circulating water supply and temperature, headwater and tailwater elevations, and electrical use.)

Net Generation: Gross generation minus plant use from all electric utility owned plants. The energy required for pumping at a pumped-storage plant is regarded as plant use and must be deducted from the gross generation.

Net Summer Capability: The steady hourly output, which generating equipment is expected to supply to system load exclusive of auxiliary power, as demonstrated by tests at the time of surnmer peak demand.

Net Winter Capability: The steady hourly output which generating equipment is expected to supply to system load exclusive of auxiliary power, as demonstrated by tests at the lime of winter peak demand.

Noncoincidental Peak Load: The sum of two or more peakloads on indivtdual systems that do not occur in the seme time interval. Meaningful only when considering loads within a linited period of time, such as a day, week, month, a heating or cooling season, and usually for not inore than I year.

Non-Firm Power. Power or power-producing capacity supplied or available under a comrnitment having limited or no assured availability.

Nonutility Power Producer. A corporation, person, agency, authority, or other legal entity or instrumentality that owns electric generating capacity and is not an electric utility. Nonutility power producers include qualifying cogenerators, qualifying small power pro. ducers, and other nonutility generators (including independent power producers) without a designated francised service area, and which do not file forms listed in the Code of Federal Regulations, Title 18, Part 141.

Nuclear Fuel: Fissionable materials that have been enriched to such a composition that, when placed in a nuclear reactor, will support a self-sustaining fission chafn reaction, producing heat in a controlled manuer for process use.

Nuclear Power Plant: A facility in which heat produced in a reactor by the firsioning of nuclear fuel is used to drive a steam turbine.

Off-Peak Gas: Gas that is to be delivered and taken on demand when demand is not at its peak. 
Ohm: The unit of measurement of electrical resistence. The resistance of a circuit in which a potentlal difference of 1 volt produces a current of 1 ampere.

Operable Nuctear Unic A nuclear unit is iq.operableseq. after it completes low-power testing and is granted authorization to operate at full power. This occurs when it receives its full power amendient to its operating license from the Nuclear Regulatory Commussion.

Outage: The pertod durfing which a generating unit, transmission line, or other factily ls out of service.

Peak Demand: The maximum load during a specified period of time.

Peak Load Plant: A plant usually housing old, low-efficiency steam units; gas turbines; diesels; or pumped-starage hydroelectric equipment normally used during the peak-load periods.

Peaking Capacity: Capacty of generating equipment normally reserved for operation during the hours of highest daily, weekly, or seasonal loads. Some generating equipment may be operated at certain times as peaking capacity and at ather times to serve loads on an around-the-dock basis.

Percent Difference: The relative change in a quantity over a specified time period. It is calculated as follows: the current value has the prevtous value subtracted from it, this new number is divided by the absolute value of the previous value; then this new number is multiplied by 100 .

Petroleum: A mixture of hydrocarbons existing in the liquid state found in natural underground reservoirs, often associated with gas. Petroleum includes fuel oil No. 2, No. 4, No. 5, No. 6; topped crude; Kerosene; and fet fuel.

Petroleum Cake: See Coke (Petroleum).

Petroleum (Crude Oil): A naturally occurring, otly, ftammable iquid composed principally of hydrocarbons. Crude oil is accasionally found in springs or pools but usually is drilled from wells benesth the earth's surface.

Ptanned Generator. A proposal by a company to install electric generating equipment at an existing or planned facility or site. The proposal is based on the owner having obtained (1) all environutental and regulatory approvals, (2) a signed contract for the electric energy, or (3) financial closure for the facility.

Plant A facility at which are located prime movers, electric generators, and auxiliary equipment for converting machanical, chemical, and/or nuclear energy into electric energy. A plant may contain mote thain one type of prime mover. Electric tuility plants exclude facitities that satisfy the definition of a qualifying facility under the Public Utiltty Regulatory Policies Act of 1978.

Plant Use: The electric energy used in the operation of a plant. Included in this definition is the energy requited for pumping at pumped-storage plants.

PIant-Use Electricity: The electric energy used in the operation of a plant. This energy tokal is subtracted from the gross energy production of the plant for reporting purposes the plant energy production is then reported as a net figure. The energy required for pumping at pumped-storage plants is, by definition, subtracted, and the energy production for these plants is then reported as a net figure.

Power. The rate at which energy is transferred. Electrical energy is usually meastured in watts. Also used for a meastrement of capacity.

Power Pool: An association of two or more interconnected electric systems having an agreement to coordinate operations and planning for improved reliability and efficiencies.

Price: The amount of money or consideration-in-kind for which a service is bought, sold, or offered for sale.

Prime Mover. The engine, turbine, water wheel, or similar machine that drives an electric generator; or, for reporting purposes, a device that converts energy to electricity directy (e.gr photovoltaic solar and fuel cell(s)).

Profit: The income remaining after all business expenses are paid.

Public Authority Service to Pablic Authorities: Public authority service indudes electricity suppited and services rendered to murriopalities or divisions or agencies of State or Federal governments, under special contracts or agreements or service classifications applicable orly to putblic authorities.

Public Street and Highway Lighting: Public street and highway lighting ikludes electricky supplied and services rendered for the purposes of lighting streets, highways, parks, and other public places; or for traffic or other signal system service, for municipalities, or other divisions or agenctes of State or Federal governments.

Pumped-Storage Hydroelectric Plant: A plant that usually generates electric energy during peak-load periods by using water previously pumped into an elevated storage reservoir during off-peak periods when excess generating capacity is available to do so. When additional generating capacity is needed, the water can be released from the reservoir through a conduit to turbine generators located in a power plant at a lower level. 
Purchased Power Adjustment A clause in a rate schedule that provides for adjustments to the bill when energy from another electric system is acquited and it varies from a spectified unit base amount.

Pure Pamped-Storage Hydroelectric Plant: A plant that produces power only from water that has previously been puriped to an upper reservoir.

Qualifying Facility (QF): A cogentration or small power production facility that meets certain ownership, operating, and effictency criterla stablished by the Federal Energy Regulatory Commission (FERC) pursuant to the Public Utility Regutatory Polictes Act (PURPA). (See the Code of Federal Regulations, Title 18, Part 292.) Part 292.

Railroad and Railway Services: Railroad and railway services include electricity supplied and services rendered to railroads and interurban and street rallways, for general tailroad use, Including the propulsion of cars or locomotives, where such electricity is stupplied under separate and distinct rate schedules.

Rate Base: The value of property upon which a utility is permitted to earn a specified rate of retum as established by a regulatory atthority. The rate base generally represents the value of property used by the utility in providing service and may be calculated by any one or a combination of the following accounting methods: fair value, prudent investment, reproduction cost, or original cost. Depending on which method is used, the rate base includes cash, working capital, materials and supplies, and deductions for accumulated provisions for depreciation, contributions in aid of construction, customer advances for construction, accumulated deferred inoome taxes, and accumulated deferred investment tax credits.

Ratemaking Authonity: A utility commission's legal authority to fix, modify, approve, ox disapprove rates, as determined by the powers given the commission by a State or Federal legislature.

Receipts: Purchases of fuel.

Regulation: The governmental function of controlling or directing economic entities trrough the process of rulemaking and adjudication.

Regerve Margin (Operating): The amount of unused available capabillty of an electric power system at peakload for a utility systent as a percentage of total capability.

Residential: The residential sector is defined as private housethold establishments which consume energy primarily for space heating, water heating, air conditioning, lighting, reftigeration, cooking and clothes drying. The classification of an individual consumer's accourt, where the use is both residential and commercial, is based on principal use. For the residential class, do not duplicate consurer accounts due to multiple metering for special services (water, heating, etc). Apartment houses are also included.

Residual Fuel Oil: The topped crude of refinery operation, inciudes No. 5 and No. 6 fuel ofl's as defined in ASTM Specification D396 and Federal Specifleation VV-F-815C; Navy Spedial fuel oil as defined in Military Specification MIL-F-859E including Amendment 2 (NATO Symbol P-77); and Burker C fuel oil, Residua! fuel cil is used for the production of electric power, space heating, vessel bunkering, and various industriaj purposes. Imports of residual fuel oil indude imported crude oil burned as fuel.

Restricted-Universe Census: This is the complete enumeration of dats from a spectfically defined subset of entities including, for example, thase that exceed a given level of sales or genfeator nameplate capacity.

RetaiI: Sales covering electutcal energy supplied for residential, commercial, and industrial end-use purposes. Other small dasses, such as agriculture and street lighting. also are induded in this category.

Revenue: The total amount of money received by a firm from sales of its products and/or services, gains from the soles or exchange of assets, interest and dividends earned on investments, and other increases in the owner's equity except those arising from capital adjustments.

Ruruting and Quick-Start Capability: The net capability of generating units that carry load or hove quick-start capability. In general, quitck-start capability refers to generating units that can be available for load within a 30-minute period.

Sales: The anount of kilowatthours sold in a given period of time; usually grouped by classes of service, such as residential, contuercial, industrial, and other. Other sales include public street and highway lighting, other sales to public authorities and raflways, and interdepertmental sales.

Sales for Resale: Energy supplied to other electric utilities, copperatives, muntipalities, and Federal and State electric agencies for resale to ultimate consumers.

Scheduled Outage: The shutdown of a generating unit, transmission line, or other facility, for inspection or maintenance, in accordance with an advance schedule.

Short Ton: A urit of weight equal to 2,000 pounds. 
Small Power Producer (SPX): Under the Ptablic Utility Regulatory Policies Act (PURPA), a small power production facility (or small power producer) generates electridty using waste, renewable (water, wind and solar), or geothermal energy as a primary energy soume. Fossil fueis can be used, but renewable resource must provide at least 75 percent of the total energy input. (See Code of Federal Regulations, Title 18, Past 292.)

Spinning Reserve: That reserve generating capacity running at a zero load and synchronized to the electric system.

Spot Purchases: A single shipment of fuel or volumes of fuel, purchased for delivery with in 1 year. Spot purchases are often made by a user to fulfill a certain portion of energy requirements, to meet unanticipated energy needs, or to take advantage of low-fuel prices.

Stability: The property of a system or element by virtue of which its output will ultimately attain a steady state. The amouns of power that can be transferred from one crachine to another following a disturbance. The stability of a power system is its abjlity to develop restoning forces equal to or greater than the disturbing forces 50 as to maintain a state of equilibrium.

Standard Industrial Classification (SIC): A set of codes developed by the Office of Management and Budget, which categorizes business into groups with similar economic activities.

Standby Facility: A facility that supports a utility system and is generally running under no-load. It is avaitable to replace or supplement a facility nomally in service.

Standby Service: Support service that is available, as needed, to supplement a consumer, a utility system, or to another utility if a schedule or an agreement authorizes the ransaction. The servfce is not regularly used.

Steam-Electric Plant (Conventional): A plant in whtch the prime mover is a steam turbine. The steam used to drive the turbine is produced in a boiler where fossil fiels are burned.

Stocks: A supply of fuel accumutlated for future use. This includes coal and fuel oil stocks at the plant site, in coal cars, tanks, or barges at the plant site, or at separate storage sites.

Subbitaminous Coal: Subbituminous coxal, or black Iigrite, is dull black and generally contains 20 to 30 percent molsture. The heat content of subbituminous coal ranges from 16 to 24 million $B$ tu per ton as received and averages about 18 million Btu per ton. Subbituminous coal, mined in the western coal fields, ts used for generating electricity and space heating.
Substation: Facility equipment that switches, changes, or regulates electric voltage.

Sulfut: One of the elements present in varying quantities in coal which contributes to environmental degradation when coral is bumed. In terms of sulfur content by weight, coal is genexally classified as low (less than or equal to 1 percent), medium (greater than 1 percent and less than or equal to 3 percent), and high (greater than 3 percent). Sulfur content is measured as a percent by weight of coal on an "as recejved" or a "dry" (moisture-free, usually part of a laboratory analysis) basis.

Switching Station: Facility equipment used to tie together two or more electric crrcuits through switches. The switches are selectively arranged to permit a circuit to be disornected, or to change the electric connection between the ctroults.

System (Electric): Physically connected generation, transmission, and distribution facilites operated as an integrated unit under one central management, or operating supervision.

Transformer: An electrical device for changing the voltage of alternating current.

Transmission: The movement or transfer of electric energy over an interconnected group of lines and associated equipment between points of supply and points at which it is transformed for delivery to consumers, or is delivered to other electric systems. Transmission is considered to end when the energy is trarsformed for distribution to the consumer.

Transmission System (Electric): An interconnected group of electric transmission lines and associated equipment for moving or transferring electric energy in bulk between points of supply and points at which it is transformed for delivery over the distribution system lines to consumers, or is delivered to other electric systems.

Turbine: A machine for generating totary mechanical power from the energy of a stream of fluid (such as water, steam, or hot gas). Turbines convert the kinetic energy of fluids to mechanical energy through the principles of inpulse and reaction, or a mixture of the two.

Uniform System of Accaunts: Prescribed finandal rules and regulations established by the Federal Energy Regulatory Corrurission for utilities subject to its jutisdiction under the authority granted by the Federal Power Act.

Useful Thermal Output: The thermal energy made available for use in any industrial or commercial process, or used in any heating or cooling application, i.e., total themal energy made available for processes and applications other than electrical generation. 
Vollage Reduction: Any intentional reduxction of system voltage by 3 percent or greater for reasons of maintaining the continuity of service of the bulk electric power supply system.

Watt: The electrical unit of power. The rate of energy trankfer equivalent to 1 ampere flowing under a pressuge of 1 volk at unity power factor.

Watthour (Wh): An electrical energy unit of measure equal to 1 watt of power supplied to, or taken from, an electric circuit stegadily for 1 hour.
Wheeling Service: The movement of electriciky from one system to another over transmission facilities of intervening systems. Wheeling service contracts can be established between two or more systems.

Wholesale Salest Energy supplied to other electric utilibies, cooperatives, municipals, and Federal and State electric agencies for resale to ultimate consumers. 